\title{
DANNIEL GOBBI
}

Identidade em ambiente virtual: uma análise da Rede Estudantes Pela Liberdade.

Maio de 2016

Brasília-DF 
DANNIEL GOBBI

IDENTIDADE EM AMBIENTE VIRTUAL:

uma análise da Rede Estudantes Pela Liberdade.

Dissertação apresentada ao Programa de Pós-Graduação do Instituto de Ciência Política da Universidade de Brasília (UnB) como requisito parcial à obtenção do título de Mestre em Ciência Política.

Orientadora: Prof ${ }^{a}$. Drª ${ }^{\text {a }}$. Marisa von

Bülow

Banca examinadora:

Dra. Marisa Von Bülow (Ipol/UnB - Presidente)

Dra. Luciana Tatagiba (IFCH/UnB)

Dra. Rebecca Abers (Ipol/UnB)

Suplente:

Dra. Debora Rezende de Almeida (Ipol/UnB)

UNIVERSIDADE DE BRASILIA

2016 
"La historia es un profeta con la mirada vuelta hacia atrás: por lo que fue, y contra lo que fue, anuncia lo que será."

Eduardo Galeano 


\section{AGRADECIMENTO}

Aos muitos que contribuíram para que eu pudesse chegar até aqui:

À minha orientadora Marisa, sempre paciente, diligente e atenciosa. Dedicou incontáveis horas, acreditou em mim e me fez acreditar que eu poderia superar meus limites. Marisa me ensinou pelo exemplo a seriedade, a humildade e a dedicação.

À minha mãe, que sempre está presente na minha vida e me apoia incondicionalmente.

Aos amigos que me ajudaram nessa caminhada. Agradeço especialmente ao Gabriel Elias, ao João Telésforo, ao Fábio Félix, ao Raduan Meira, ao Rafael de Acypreste, ao Vitor Magalhães e ao Edemilson Paraná, pelas longas conversas e reflexões. Vocês também são parte desse trabalho.

Aos professores do IPOL, por cada dúvida, questionamento e esperança que me trouxeram: à Rebecca Abers, à Flávia Biroli, ao Luiz Felipe Miguel e ao Paulo Calmon.

Aos meus colegas do IPOL com quem compartilhei essa caminhada, em especial à Bia Franco, ao Luiz Vilaça e à Tayrine Santos, que me inspiraram e me ajudaram.

Ao meu amigo e assistente de pesquisa, Ian Viana, que me ajudou no trabalho de classificação dos dados e ao Rafael de Acypreste, pela Revisão

Aos meus colegas de trabalho e às minhas chefes, Fernanda Machiaveli e Cristina Timponi.

Ao professor Marcelo Kunrath pela base de textos que organizou e ao projeto Sci Hub por facilitar o acesso ao conhecimento.

E a todos os demais que contribuíram nessa caminhada, 


\section{Lista de Abreviações}

$\begin{array}{ll}\text { API } & \text { Application Programming Interface } \\ \text { APL } & \text { Aliança Pela Liberdade } \\ \text { DCE } & \text { Diretório Central dos Estudantes } \\ \text { DEM } & \text { Partido Democratas } \\ \text { DOS } & \text { Denial of Service } \\ \text { EPL } & \text { Estudantes Pela Liberdade } \\ \text { EUA } & \text { Estados Unidos da América } \\ \text { IrC } & \text { Internet Relay Chat } \\ \text { ITA } & \text { Instituto Tecnológico da Aeronáutica } \\ \text { MBL } & \text { Movimento Brasil Livre } \\ \text { MP } & \text { Mercado Popular } \\ \text { NRA } & \text { National Rifle Association } \\ \text { PDA } & \text { Publica Data Access } \\ \text { PMDB } & \text { Partido do Movimento Democrático Brasileiro } \\ \text { PP } & \text { Partido Progressista } \\ \text { PR } & \text { Partido da República } \\ \text { PSB } & \text { Partido Socialista Brasileiro } \\ \text { PSDB } & \text { Partido da Social Democracia Brasileira } \\ \text { PSL } & \text { Partido Social e Liberal } \\ \text { PT } & \text { Partido dos Trabalhadores } \\ \text { PUC-RJ } & \text { Pontifícia Universidade Católica do Rio de Janeiro } \\ \text { SFL } & \text { Students For Liberty } \\ \text { UFPE } & \text { Universidade Federal de Pernambuco } \\ \text { UFRGS } & \text { Universidade Federal do Rio Grande do Sul } \\ \text { UnB } & \text { Universidade de Brasília } \\ \text { YAL } & \text { Young Americans for Liberty }\end{array}$




\section{Índice de Figuras}

Figura 1 - Foto dos participantes da conferência - do autor ............................ 46

Figura 2- Capa do relatório trimestral EPL Outono de 2015 ............................ 61

Figura 3 - Instantâneo de tela de web cache do sítio eletrônico do EPL.......... 63

Figura 4 - Categorias de publicação por organização ….................................. 81

Figura 5 - Categorias das publicações dos administradores na página do

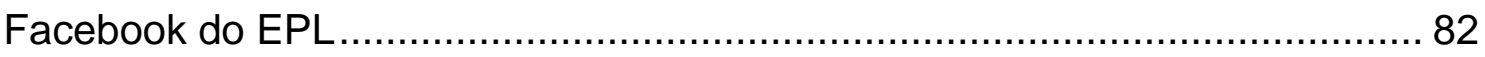

Figura 6 - Categorias das publicações dos administradores na página do

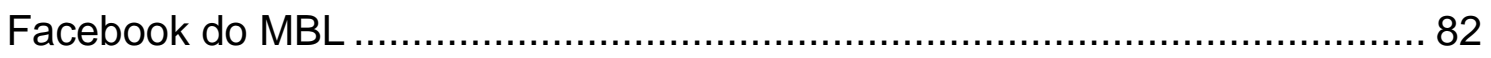

Figura 7 - Categorias das publicações dos administradores na página do

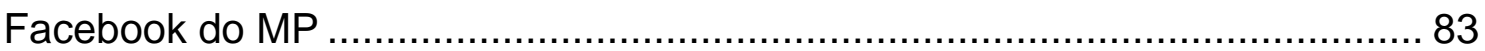

Figura 8-Gráfico da rede de curtidas a partir do EPL em 12/02/2015 .............. 88

Figura 9 - Gráfico da rede de curtidas a partir do MBL em 12/02/2016 ............ 91 


\section{Sumário}

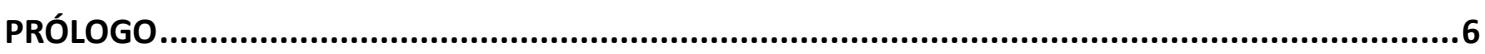

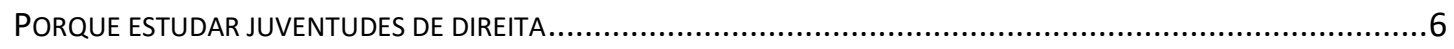

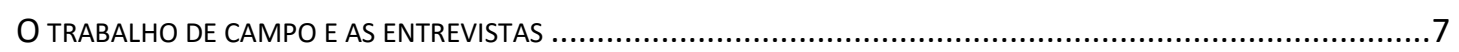

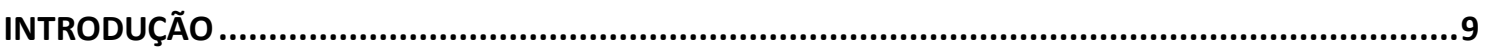

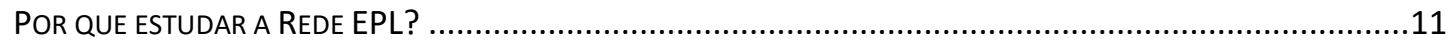

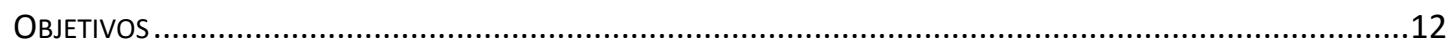

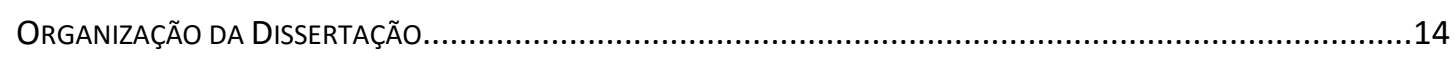

1. METODOLOGIA: BASES DE DADOS DIGITAIS E ENQUADRAMENTOS ANALÍTICOS ................16

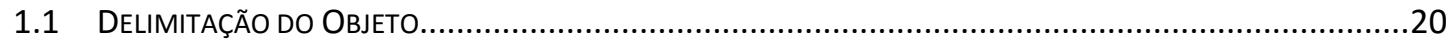

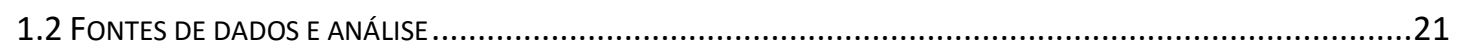

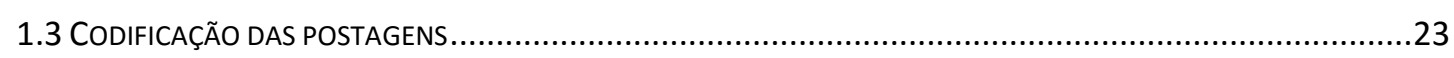

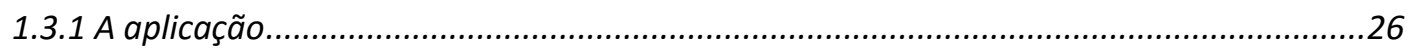

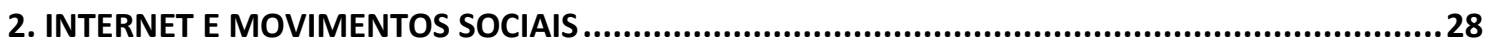

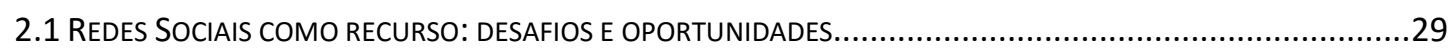

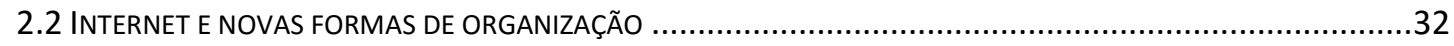

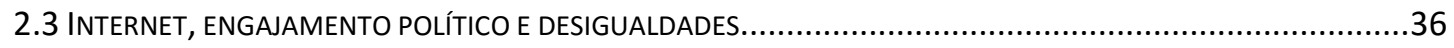

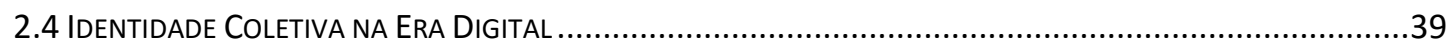

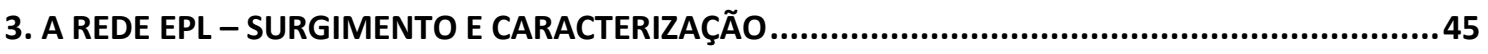

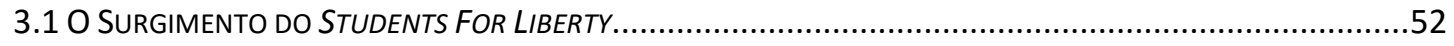

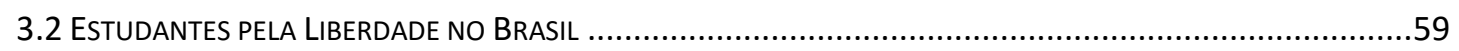

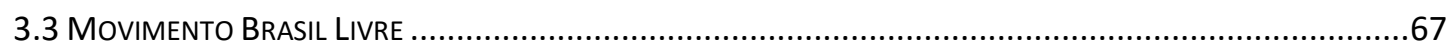

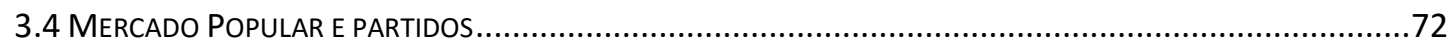

CAPÍTULO 4 - FERRAMENTAS DIGITAIS E IDENTIDADE NA REDE EPL .........................................75

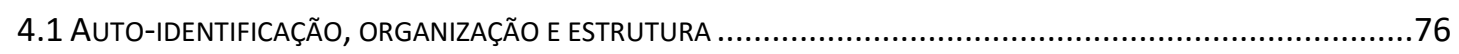

4.2 REDE EPL: ANÁLISE GRÁFICA A PARTIR DA REDE DE CURTIDAS NO FACEBOOK........................................8

4.2.1 Rede EPL: análise gráfica a partir da rede de curtidas no Facebook ..............................88

4.2.2 Rede MBL: análise gráfica a partir da rede de curtidas no Facebook..............................91

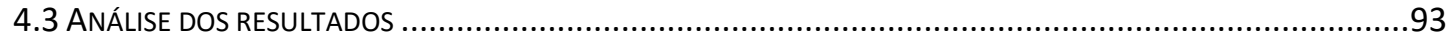

CONCLUSÃO

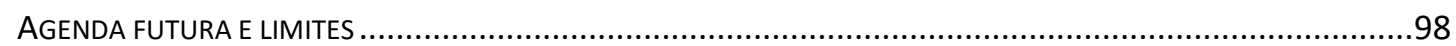

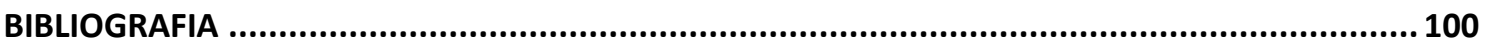

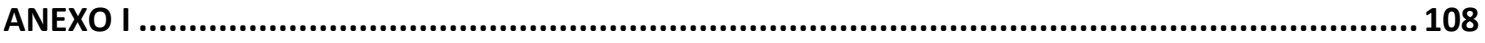

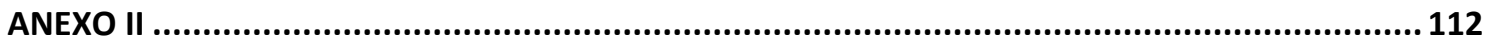

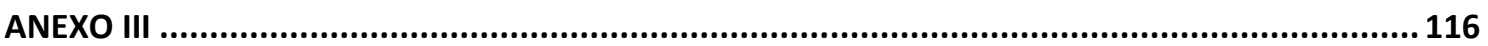

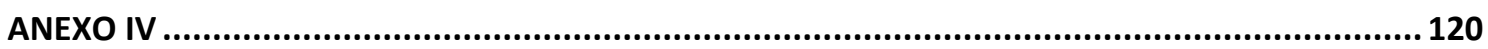




\section{Prólogo}

Quando embarquei na experiência de estudar um grupo que defende algo tão diferente do que acredito, decidi não apenas conhecer um pouco mais sobre a diversidade do pensamento humano e os processos que estão tomando de surpresa 11 em cada 10 analistas políticos em nosso país, mas decidi também conhecer melhor a mim mesmo. Ampliar o escopo de visão é ganhar uma percepção mais apurada sobre o seu próprio lugar no mundo. É entender sua posição política em um espectro mais amplo e saber, com maior domínio, o que nos aproxima e nos diferencia do outro.

Embarcar numa experiência dessa natureza só pode frutífera, se for com a abertura, a alteridade e o senso crítico que também defendemos como princípios para uma política mais justa e inclusiva. Pois assim também deve ser feita a busca pelo conhecimento: guiado pela mais elevada curiosidade, pela sensibilidade com o outro e pela capacidade de compreender, mais do que defender ou julgar, seu objeto-sujeito de estudo. E dessa preocupação emerge um cuidado com a não-caricaturização dos sujeitos e grupos analisados e com o rigor no tratamento e análise dos dados levantados.

\section{Porque estudar juventudes de direita}

Quando comecei a estudar o que denomino de Rede EPL - formada pelas organizações Movimento Brasil Livre, Mercado Popular, além do próprio Estudantes Pela Liberdade e algumas dezenas de pequenos coletivos a ela conectados -, poucas pessoas acreditariam que a conjuntura política no Brasil mudaria de maneira tão rápida. Eu tampouco tinha essa expectativa, mas fui levado por outros motivos a estudar a Rede EPL.

Meu primeiro contato com essa rede se deu com o coletivo Aliança Pela Liberdade na Universidade de Brasília, cuja fundação testemunhei poucos meses de completar minha graduação na Universidade de Brasília. Aquele coletivo político era um estranho no ninho do movimento estudantil não só pelas ideias que apresentava, mas pelos objetivos que perseguia. Cerca de dois anos depois, a aliança conquistou o DCE da Universidade de Brasília. Nesse mesmo período, outros coletivos de natureza semelhante foram surgindo em diversas 
universidades brasileiras e alguns poucos também lograram o mesmo êxito da Aliança pela Liberdade.

Com o tempo, comecei a perceber sinais cada vez mais claro de que esse era um movimento de juventude que havia se profissionalizado e atuava em forte conexão com uma rede internacional e organizações de outras naturezas, como filantropias, empresas e fundações partidárias estrangeiras. O que mais me surpreendia, entretanto, era a maneira estruturada e eficaz com que essas organizações faziam uso das mídias sociais. Ao perceber que pouco ou nada fora produzido sobre o engajamento dessa Rede nas plataformas digitais, decidi tomar esse tema como meu objeto de estudo e recebi total apoio e suporte da minha Orientadora, Marisa, que havia recentemente retornado do Chile, onde se dedicou exitosamente a estudar engajamento militante do movimento estudantil daquele país em mídias sociais.

\section{O trabalho de campo e as entrevistas}

Quando comecei a desenhar meu projeto de pesquisa, percebi que não seria possível fazer uma análise do engajamento da Rede EPL nas mídias sociais, sem uma pesquisa de campo que me permitisse compreender melhor o que é a Rede EPL, qual a sua constituição e como ela se estrutura. Ao mesmo tempo, já poderia antever dificuldades em fazer um trabalho de campo mais intenso por não pertencer à Rede e poder gerar um eventual estranhamento.

Não obstante essas possíveis dificuldades, consegui fazer sete extensas e exitosas entrevistas, além de ter participado de uma Conferência nacional de dois dias e de ter visitado um acampamento do $\mathrm{MBL}$ em frente ao Congresso Nacional. Ao começo de todas as abordagens, apresentava-me informando meu nome e explicando exatamente meu tema de estudo e os objetivos analíticos a que me propunha. Em geral, fui recebido com bastante abertura e entusiasmo pelos entrevistados, que me foram bastante generosos com o tempo e a confiança dispendidas. A reação entusiasmada se traduziu em poucas ou nenhuma pergunta sobre minha origem, minhas crenças políticas e sobre minha pesquisa, mas em bastante interesse em guiar-me pelo processo de 
compreensão da atividade política deles - o que também precisa ser tratado com cuidado.

Ao final, acredito que a experiência de explorar um campo com o qual não tenho afinidade foi facilitado pelo escopo de minha pesquisa, que não incluía a valoração ideológica dos projetos políticos das organizações, pela pesquisa prévia ao trabalho de campo, que me trouxe conceitos e elementos discursivos que facilitaram o diálogo com meus interlocutores, e, principalmente, pela dedicada orientação e acompanhamento que recebi da professora Marisa von Bülow, que me demostrou, com bastante clareza, que o conhecimento é mais resultado do trabalho de coletividades, do que de esforços individuais. 


\section{Introdução}

O rápido crescimento da direita no Brasil e o uso cada vez mais profissionalizado das plataformas digitais por organizações políticas são dois fenômenos que estão transformando politicamente a segunda década do século XXI.

Se, por um lado, há uma escassez de estudos sobre a direita no Brasil, por outro, muitos esforços têm sido empenhados pela academia nas últimas décadas para investigar os impactos que os usos da internet têm na ação coletiva, em especial no que se refere às formas de organização, aos repertórios de ação disponíveis e à formação da identidade dos movimentos sociais. Não obstante os avanços analíticos obtidos neste último tema, as constantes inovações tecnológicas suscitam cada vez mais questões de pesquisa ao alterar ininterruptamente a natureza das plataformas estudadas, ao ampliar as possibilidades epistemológicas derivadas das novas ferramentas analíticas e novos métodos de investigação e ao permitir o acesso a grandes bases de dados.

A ascensão recente da direita no Brasil, em contraste com a reeleição de Dilma Rousseff para o quarto mandato seguido do Partido dos Trabalhadores (PT) na presidência do Brasil, é um acontecimento surpreendente que quebra com a predominância daquilo que Madeira e Tarouco (2010) denominaram de "direita envergonhada". Essa mudança no cenário político está levando a direita no Brasil a ganhar cada vez mais espaço na agenda de pesquisadores e analistas políticos, transformando-se em esforços que ainda precisam ser bastante aprofundados.

A presente dissertação faz um estudo de caso que está na intersecção desses dois fenômenos, analisando a apresentação de identidade em mídias sociais de uma rede de juventude de direita no Brasil formada pela organização Estudantes pela Liberdade (EPL) e outras duas surgidas a partir dela: o Movimento Brasil Livre (MBL) e o Mercado Popular (MP). O conjunto dessas três organizações, que inclui dezenas de coletivos satélites associados ao $E P L$, é o que denomino de Rede EPL. Trata-se de uma rede informal com duas organizações que, formadas a partir do EPL, compartilham dirigentes com ele. Essas três 
organizações ainda têm em comum o fato de serem lideradas por jovens e se encontrarem no espectro político da direita.

A localização dessa rede no campo da direita é evidenciada por três fatores: pela sua posição política relacional contra a esquerda ${ }^{1}$; pela autoidentificação das organizações com diversas tradições políticas do campo da direita, como o anarco-capitalismo, o liberalismo econômico, o libertarianismo, o minarquismo e o conservadorismo; e pelo resultado da análise de redes de curtidas entre páginas $^{2}$ no Facebook - explorada no Capítulo 4 dessa dissertação -, que mostra a sua inserção em um conjunto de organizações do espectro de atores políticos da direita brasileira.

A partir do estudo de caso proposto, esta dissertação contribui para a melhor compreensão de três lacunas da literatura mais recente sobre ação coletiva e Internet. A primeira delas refere-se à predominância de estudos sobre movimentos sociais do hemisfério norte ou sobre a Primavera Árabe (GARCÍA et al., 2014), implicando em poucas pesquisas relativas a outros tipos de movimentos do hemisfério sul. A segunda refere-se à ausência de uma tradição brasileira de estudos sobre a direita (TATAGIBA; TRINDADE; TEIXEIRA, 2015), algo que Clifford Bob (2012) aponta como sendo um fenômeno global: a predileção da Academia por estudar a esquerda. A terceira diz respeito ao baixo número de pesquisas que se dedicam à relação entre questões de identidade coletiva e usos da Internet (GERBAUDO; TRERÉ, 2015).

Ao longo desta dissertação, também ofereço algumas contribuições para duas questões de pesquisa postuladas por Metaxas, Mustafaraj e Gayo-Avello (2011, p.171) sobre a natureza da conversação política em redes sociais digitais e sobre a maneira com que diferentes grupos ideológicos e ativistas buscam criar influência nessas redes sociais. Este estudo de caso não pretende, entretanto,

\footnotetext{
${ }^{1}$ Critério utilizado por Tatagiba, Teixeira e Trindade (2015, p.2) em pesquisa sobre os protestos à direita no Brasil.

2 O termo Página é equivalente a fan page e se refere a "uma marca, entidade (local ou organização) ou figura pública" [ ver https://www.facebook.com/page guidelines ] e se diferencia dos perfis que são espaços privados dos usuários, e só podem representar pessoas físicas.
} 
esgotar as questões de pesquisa enunciadas, mas contribuir para o aumento do acúmulo analítico existente.

\section{Por que estudar a Rede EPL?}

A maneira como as organizações e coletivos dessa rede se tornaram atores com capacidade de impacto na disputa política no movimento estudantil e em movimentos de rua tornam a Rede EPL um objeto de pesquisa relevante. Desde que foi fundado, o Diretório Central de Estudantes (DCE) da Universidade de Brasília (UnB) foi dirigido por coletivos autoidentificados como pertencentes à esquerda. Em 2011, pela primeira vez, um grupo de estudantes que se afirmava liberal - denominado Aliança pela Liberdade (APL) - conquistou a direção do DCE da UnB, na qual permanece até o presente momento. A vitória do grupo de Brasília, combinada com a vitória do Movimento Estudantil Livre para o DCE da Universidade Federal do Rio Grande do Sul (UFRGS), pavimentou caminho para que outros grupos que fazem parte dessa rede de direita liberal se fortalecessem. Esses grupos conseguiram, entre outros feitos, dirigir o DCE da Universidade Federal de Minas Gerais (UFMG) e da Pontifícia Universidade Católica do Rio de Janeiro (PUC-RJ), possibilitando também o fortalecimento de outros grupos do mesmo matiz ideológico Brasil afora, como ocorreu na Universidade de São Paulo e na Universidade Federal de Pernambuco (UFPE).

Nas manifestações de rua e nas disputas políticas gerais no Brasil, o MBL se destaca como liderança antipetista. Suas ações e manifestações pelo impeachment da Presidenta Dilma Rousseff o coloca, junto ao grupo Vem Pra Rua e ao Revoltados Online, como protagonista desse novo fenômeno da direita brasileira.

Esta dissertação propõe estudar a Rede EPL especificamente a partir dos usos da Internet em processos de construção de identidades. O foco na Internet justifica-se pela centralidade que esta tem na construção da Rede estudada. $O$ intenso uso das ferramentas digitais para a comunicação interna e externa das organizações que compõem a Rede EPL pode ajudar a analisar o impacto das mídias sociais sobre os processos políticos, em especial sobre a apresentação de identidade da "nova" direita brasileira. 
Para melhor compreender a origem e as conexões da Rede EPL, também incluo dados sobre a rede transnacional em que se insere. Conforme afirma Michel Löwy $^{3}$, o fenômeno de ascensão da Direita, inclusive de seus matizes mais extremistas, é global, exigindo maior esforço em compreender as redes conectadas internacionalmente. A estruturação de uma rede transnacional de juventude de direita no Brasil representa também a oportunidade de estudar a formação de um novo ator político e o impacto que a utilização das plataformas digitais tem sobre as organizações e sobre como os movimentos sociais se identificam.

\section{Objetivos}

O principal objetivo desta dissertação é compreender o que os usos da Internet podem expressar sobre a identidade coletiva de organizações política. Mais especificamente, interessa analisar como organizações políticas enfrentam 0 dilema entre coesão e expansão na sua estratégia de comunicação em mídias sociais - entendido como a tensão entre aprofundar a definição da identidade do movimento (coesão) ou ampliar o seu alcance público por meio da abertura e indefinição de alguns elementos de sua identidade (expansão). Se mantiver maior controle sobre a concepção e os requisitos identitários, a organização ganha em unidade e comprometimento, mas se torna acessível apenas a um público mais restrito. Se decidir ampliar seu alcance, internalizará uma série de contradições e concepções divergentes, que reduzirão a variedade de ações políticas possíveis, mas possibilitando a interlocução com um contingente maior de pessoas.

Para o fins desse trabalho, identidade coletiva é compreendida como uma definição dinâmica e compartilhada, produzida por diversos indivíduos em interação, preocupados com a orientação de suas ações e com o campo de oportunidades e restrições que as envolvem (MELUCCI, 1989). Assim, identidade coletiva não é dada como uma formulação estática de um grupo, como uma definição realizada em algum ato fundacional e carregada ao longo

\footnotetext{
${ }^{3}$ Dez teses sobre a ascensão da extrema direita europeia. Folha de São Paulo, llustríssima, São Paulo, v. 15, 2014. 2 Disponível em http://www.bresserpereira.org.br/terceiros/2014/junho/14.06.Teses-ascens\%C3\%A3o-extremadireita-europeia.pdf
} 
do tempo até que outra decisão a modifique. Nesses termos, Melucci (1996) explica que a identidade coletiva é responsável por garantir a continuidade e permanência do movimento ao longo do tempo.

O dilema entre coesão e expansão é adaptado a partir de outro dilema enfrentado por organizações de movimentos sociais que utilizam plataformas digitais, formulado por von Bülow (2016), entre a necessidade de manter maior controle sobre as concepções e as decisões a respeito de estratégia, mas, ao mesmo tempo, obter o máximo de benefícios possíveis dos usos da internet. Tratando das disputas internas nas dinâmicas do processo decisório e no controle organizacional, o dilema formulado por von Bülow enfoca o papel das lideranças $e$ as escolhas excludentes que precisam fazer entre obter os benefícios que os usos da internet podem trazer - em especial, mas não exclusivamente a expansão de seu alcance - e a manutenção do controle sobre os processos organizacionais.

A questão central no dilema entre coesão e expansão está, de outro modo, ligado a uma dimensão relacional da organização com sua base e seu público externo. A maneira com que a comunicação é construída não apenas seleciona o público, como influencia na forma com que os vínculos entre os seus componentes são construídos. Nesse caso, uma estratégia de comunicação mais esvaziada de propostas e de posicionamentos em questões polêmicas amplia a identidade da organização, aumentando a sua diversidade, mas reduz a coesão entre seus membros.

Por meio da análise de entrevistas e de postagens no Facebook, busco identificar de que maneira cada uma das três organizações estudadas opta, em sua estratégia digital, por maior afirmação identitária, aumentando sua unidade organizacional, ou pela expansão de sua interlocução, reduzindo sua unidade identitária.

Ao coesionar sua identidade, uma organização aumenta o grau interno de unidade e comprometimento de seus membros - selecionando aqueles que se identificam profundamente com a organização e aumentando os processos de formação -, mas reduz significativamente o escopo de sua base ao excluir todos 
aqueles que possuem restrições com os requisitos identitários colocados ou que neles não se enquadrem. Ao expandir uma identidade, por outro lado, uma organização amplia a sua base política, permitindo uma diversidade maior de indivíduos, ao mesmo tempo em que reduz o grau de unidade e comprometimento - tão importantes para a ação política.

Esse não se trata, entretanto, de um dilema perfeito, em que apenas duas escolhas mutuamente excludentes são possíveis. A diversidade de formas pelas quais a identidade pode ser construída no processo de interação das mídias sociais também cria múltiplas estratégias possíveis. Como argumento no quarto capítulo dessa dissertação, essas estratégias estão diretamente conectadas com a finalidade da organização e com o tipo de público que ela busca alcançar.

Esta dissertação tem ainda outros dois objetivos específicos: mapear os vínculos entre a Rede EPL e outros atores políticos; e analisar as tensões existentes no reconhecimento do caráter internacional da Rede.

\section{Organização da Dissertação}

Para alcançar os objetivos expostos anteriormente, a presente dissertação está organizada em quatro capítulos. Dada a necessidade de apresentar uma discussão detalhada sobre a metodologia utilizada nesta dissertação, optei por apresentá-la em separado. Assim, o primeiro capítulo apresenta brevemente o debate sobre os limites e potencialidades dos dados sobre usos da Internet. Em seguida, realizo uma descrição da metodologia utilizada na pesquisa, discriminando as fontes de dados, as ferramentas e os métodos analíticos escolhidos, além de uma delimitação do objeto de pesquisa.

O segundo capítulo apresenta uma sistematização da discussão teórica sobre os impactos dos usos da Internet na ação coletiva, com ênfase em quatro questões de pesquisa. A primeira faz referência à literatura sobre repertórios de ação coletiva e aborda a questão das oportunidades e desafios organizacionais que são criados com a disseminação das ferramentas digitais. A segunda aborda os trabalhos sobre novas lógicas de organização que surgem a partir dos usos da Internet. A terceira trata de mecanismos, de processo político e dos comportamentos sociais associados à disseminação das ferramentas digitais. $\mathrm{A}$ 
quarta busca entender, em uma perspectiva que mobiliza os três debates anteriores, de que maneira se dá a formação de identidades nos espaços digitais. A partir deste último debate, desenvolvo o argumento do dilema entre coesão e expansão.

O terceiro capítulo apresenta o processo de surgimento da Rede EPL. Para tanto, o capítulo explica como surgiu a organização Students For Liberty (SFL) nos Estados Unidos, sua estratégia de expansão no Brasil e os resultados que advieram desse processo: a fundação do Movimento Brasil Livre, a fundação do Instituto Mercado Popular e a entrada concertada das lideranças desses movimentos em dois partidos distintos, o Partido Novo e o Partido Social e Liberal (PSL). Sempre que usar o termo Students For Llberty nessa dissertação, estarei me referindo à organização transnacional, enquanto o uso do termo Estudantes Pela Liberdade refere-se exclusivamente à organização no Brasil.

O quarto capítulo apresenta o debate sobre o dilema entre coesão e expansão, a partir da análise empírica dos elementos identitários de cada organização. Essa análise é feita a partir de fontes documentais, das entrevistas e do conteúdo das postagens nas páginas das organizações no Facebook. Nesse capítulo, apresento também a análise das redes do EPL, do MBL e do MP a partir da extração das curtidas entre organizações no Facebook, com base na Rede Ego (ou egocentrada) do EPL e do MBL, o que ajuda a compreender melhor os campos políticos nos quais se inserem essas organizações ${ }^{4}$. Ainda nesse capítulo, faço algumas reflexões sobre como as três organizações adotam estratégias diferentes para enfrentar o dilema entre coesão e expansão.

Por fim, a conclusão desta dissertação busca sistematizar algumas contribuições ao debate sobre como as organizações estudadas constroem suas identidades nas plataformas digitais - com destaque para o Facebook - registrando alguns achados da presente dissertação.

\footnotetext{
${ }^{4}$ Os procedimentos e a metodologia de análise gráfica da rede de curtidas estão explicados
} detalhadamente no Capítulo 1. 


\section{Metodologia: bases de dados digitais e enquadramentos analíticos}

O debate sobre os impactos da internet nas relações sociais e nas instituições tensiona os limites dos paradigmas tradicionais aplicados ao campo da Ciência Política (NIELSEN, 2011a; TOLLE; TANSLEY; HEY, 2011), não apenas porque a tecnologia abre novas fronteiras analíticas e traz novas perspectivas epistemológicas (CASTELLS, 2002), como também porque impacta significativamente os sujeitos políticos (FARRELL, 2012; WELLMAN et al., 2001). Como efeito do uso crescente de novas plataformas comunicativas, outras lógicas de organização coletiva se tornam possíveis, impactando diretamente o cenário político (BENNETT; SEGERBERG, 2012) e mobilizando, por conseguinte, um grande esforço da comunidade acadêmica para a compreensão desses fenômenos(GARRET, 2006).

O extenso volume de dados, denominado na literatura de big data ${ }^{5}$, reaviva uma disputa fundamental do debate metodológico das Ciências Sociais no século XX, entre quantitativistas - na defesa dos métodos matemáticos, optando por buscar um modelo próprio das ciências naturais - e qualitativistas - que preferem o trabalho com observações e buscam formar conhecimento por meio da interpretação e do enquadramento teórico (LATOUR, 2010).

De um lado, o quantitativismo se fortalece pelos entusiastas da big data e na defesa de que é possível avançar de maneira mais segura nas Ciências Sociais analisando-se questões estruturais, trabalhados por meio de indicadores, fórmulas e codificação de linguagem natural. De outro, encontram-se os pesquisadores mais voltados ao desenvolvimento dos processos interpretativos, que preferem os métodos de análise e levantamento de dados voltados para a busca de significados e que avaliam com cautela - e até mesmo preocupação ética - as grandes bases informatizadas (GIL DE ZUNIGA, 2015; LAZER et al., 2014).

\footnotetext{
${ }^{5}$ Big Data não se refere apenas a grandes conjuntos de dados e a ferramentas e procedimentos usados para manipular e analisá-los, mas também a uma mudança no pensamento computacional e na pesquisa (Burkholder 1992; apud Boyd e Crawford, 2012, tradução nossa)
} 
Essas grandes bases de dados registram até mesmo detalhes sobre a atividade de navegação dos usuários em plataformas digitais - o que clicaram, quais páginas visitaram, o que digitaram nos formulários e quanto tempo permaneceram. Elas são largamente utilizadas para o direcionamento de conteúdo e para ofertas de publicidade por empresas que possuem acesso a essas bases, como as criadoras de navegadores online ou de mecanismos de busca (LAZER et al., 2014; METAXAS; MUSTAFARAJ, 2012). Ao saber que um usuário pesquisou sobre passagem aérea para uma determinada cidade, uma empresa pode direcionar, com maior probabilidade de acerto, publicidade relacionada a locação de automóvel, hotelaria e outros serviços turísticos, por exemplo.

Para as Ciências Sociais, o uso das bases de dados digitais também traz importantes informações sobre redes, conexões, usos das plataformas digitais, capacidade de influência de atores e disponibilidade de recursos, além de possibilitar a criação de novas métricas de rede (CALERO VALDEZ et al., 2012; RIEDER, 2013), mas sem necessariamente prescindir dos modelos e sistemas analíticos oriundos de processos interpretativos da realidade (LAZER et al., 2014). Como destaca Gil de Zuñiga (2015, p.3):

(...) in order to better understand the fluid, high-speed world of social media and politics, we still rely on basic principles of social science: validity of constructs, theory that stresses context, generalizability, and ethical concerns.

A análise dos usos de redes sociais digitais ainda exige do pesquisador um processo de limpeza de dados que inclui a decisão sobre quais atributos e variáveis devem ser incluídas e quais devem ser ignoradas (BOYD; CRAWFORD, 2012), como em qualquer processo de modelagem científica. Os métodos de sistematização desses dados e as teorias que dão suporte à utilização desses métodos ainda estão em debate e enfrentam grandes desafios, em especial sobre como derivar interpretações válidas e sobre o tratamento que deve ser dado aos sujeitos envolvidos (GIL DE ZUNIGA, 2015).

Outros desafios metodológicos enfrentados pelo campo referem-se à natureza das plataformas digitais e das ferramentas de extração, análise e visualização de dados utilizadas. Com o surgimento de novas alternativas, plataformas e 
ferramentas se tornam obsoletas, exigindo novo esforço analítico da comunidade acadêmica para compreender a cognição e as funcionalidades das tecnologias emergentes.

Entre as plataformas de redes sociais, o processo de obsolescência é ainda mais intenso. IRC, ICQ, Orkut e listas de discussão tornaram-se ferramentas em desuso - algumas delas com base de dados indisponibilizadas ao acesso público. Há também as ferramentas que não se tornaram obsoletas, mas perderam algumas de suas funcionalidades ou ganharam outros usos, como é o caso dos blogs e fotologs (GARCíA et al., 2014). Mais recentemente, Instagram, Whatsapp, Snapchat e Telegram assumiram parte das funções de aplicativo de mensagens instantâneas, de rede social de imagens ou de grupo de discussão antes concentradas no Facebook. Dessa maneira, é arriscado replicar um mesmo enquadramento analítico utilizado em pesquisas anteriores sem antes verificar se as premissas sobre os valores e os usos atribuídos à plataforma estudada continuam válidas.

Outro fator importante diz respeito às modificações nos códigos-fonte que alteram as regras de utilização das plataformas, os mecanismos de interação e as ferramentas à disposição dos usuários (FEITELSON; FRACHTENBERG; $B E C K, 2013)$. Esse tipo de mudança incide sobre a cognição dos usuários e seus padrões de relacionamento (BUCHER, 2012), o que pode afetar os resultados obtidos, em especial se o estudo considerar longas séries temporais. Essas variações no comportamento, entretanto, podem ser incorporadas como um fator endógeno nos estudos que busquem registrar a dinâmica da relação entre usuário e plataforma, sem fazer generalizações sobre fatores comportamentais ou sobre as percepções dos usuários, já que não haveria homogeneidade das condições de interação na plataforma ao longo do tempo.

Mudanças na Interface de Programação de Aplicação (API) ${ }^{6}$, por sua vez, incidem diretamente sobre os métodos de mineração e análise de dados - o que

${ }^{6}$ API (Application Programming Interface) é a interface, compreendida como convenções de rotinas e padrões, por meio do qual um aplicativo acessa um sistema operacional e outros serviços. Um API é definido no código-fonte e fornece o nível de abstração entre o aplicativo e o kernel (ou outros utilitários privilegiados) para garantir a portabilidade do código (tradução minha).. Definição extraída de <http://foldoc.org/Application\%20Program\%20Interface >. Acesso em: 22/01/2016 
pode impossibilitar o processo de verificação das premissas de um estudo anterior ou mesmo de replicação dos seus métodos para outro estudo.

Essa dificuldade de padronização nas técnicas de coleta e monitoramento de plataformas digitais é ainda reforçada por outro fenômeno comum: as alterações constantes nas ferramentas de mineração de dados, de análise e de visualização gráfica, que ocorrem como resultado de esforços para melhorar os procedimentos dos softwares e como resposta às mudanças no código-fonte e no API das plataformas digitais. Assim, essas mudanças nas ferramentas são também resultantes de novas contribuições de métodos e enquadramentos analíticos, que ajudam no avanço do campo de estudo.

Como salienta Kuhn (1998, p. 93), algumas crenças ou procedimentos anteriormente aceitos precisam ser descartados e simultaneamente substituídos por outros para que haja avanço científico. No que se refere aos métodos digitais, essas mudanças ocorrem rapidamente devido aos avanços dos instrumentos e procedimentos utilizados, mas também são freadas pelos bloqueios que administradores e empresas proprietárias das plataformas digitais criam à mineração e análise de dados.

Ainda que apresentem os limites expostos, as bases de dados digitais e os métodos de análise a elas aplicáveis têm criado novas e importantes oportunidades de pesquisa. Apesar do uso dessas fontes de dados ser ainda muito incipiente no Brasil, nos últimos anos, percebe-se um crescimento de publicações e projetos de pesquisa baseados em dados digitais, como demonstra a criação do Grupo de Trabalho de Ciberpolítica, Ciberativismo e Cibercultura da ANPOCS em $2011^{7}$, devido aparentemente ao interesse gerado pela eclosão de diversos protestos organizados com o uso das redes sociais virtuais.

Para compreender melhor os procedimentos analíticos e o enquadramento da pesquisa aplicado a essa dissertação, esse capítulo apresenta três seções. A primeira delimita o objeto de estudo. A segunda aborda as fontes de dados e os

7 Consta da lista divulgada em http://www.anpocs.org.br/portal/images/gts35eaa.pdf. Desde então, o GT permanece ativo em cada nova edição do encontro anual da Associação 
procedimentos de análises utilizados. A terceira explica o processo de codificação das postagens.

\subsection{Delimitação do Objeto}

No levantamento inicial de dados sobre quais eram as organizações próximas do grupo Estudantes Pela Liberdade, identifiquei três categorias de organizações. A primeira contém algumas dezenas de grupo regionais do EPL e grupos políticos, como a Aliança Pela Liberdade, o Movimento Estudantil Livre e o Coletivo Nabuco, que formam o EPL nacionalmente. Enquanto os grupos regionais se estruturam de maneira hierarquizada, divididos por critérios territoriais, os coletivos são geridos de maneira relativamente autônoma, mas sob a direção das lideranças formadas pelo EPL.

A segunda se refere a organizações externas que foram criadas e são dirigidas por membros do EPL, entre as quais se destacam o Instituto Mercado Popular (MP), o Movimento Brasil Livre (MBL) e a recém-criada tendência Livres do Partido Social e Liberal.

A terceira é composta por diversas Fundações, Think Tanks e Institutos que apoiam a rede EPL no Brasil, financeira ou intelectualmente, tais como o Instituto Liberal, o Instituto Millenium, a Atlas Network, o Instituto Van Mises, o Instituto de Estudos Empresariais, o Instituto Catho, a Friedrich Naumann Stiftung e o Instituto Ordem Livre.

Esse terceiro conjunto de organizações não foi incluído no foco de análise por tratar-se de um grupo de apoiadores. Do segundo grupo, foram incluídos tanto o MBL, quanto o MP, excluindo a tendência Livres do Partido Social e Liberal, apesar da sua evidente relevância política. Essa exclusão foi necessária dado que a organização Livres ainda estava em constituição e pouca informação seria obtida a respeito. O primeiro grupo, para fins analíticos, foi representado pela direção nacional do EPL. Dessa maneira, o estudo de caso dessa dissertação foi construído em torno da análise dessas três organizações centrais: MBL, MP e EPL. 


\subsection{Fontes de dados e análise}

Nesse trabalho, foram utilizados quatro tipos de fontes de dados principais: entrevistas semiestruturadas com sete lideranças; 8604 postagens das páginas das organizações no Facebook, referentes aos anos de 2014 e 2015; a rede de curtidas entre as páginas das organizações no Facebook; e, subsidiariamente, as publicações nos sítios oficiais das organizações estudadas. Outros documentos enviados ou recomendados pelos atores entrevistados também foram considerados no processo analítico. De maneira complementar, foi feita observação participante durante o Encontro Nacional do EPL e em visita ao acampamento do MBL na Esplanada dos ministérios, ambos em outubro de 2015.

Nas entrevistas, os interlocutores puderam discorrer sobre as organizações de que participam e sobre a importância que atribuem às plataformas digitais. Nelas, foi possível identificar elementos em comum e distintivos entre as organizações, pontos de disputa, estratégias políticas compartilhadas e as percepções de cada ator. As entrevistas foram realizadas presencialmente ou por telefone e conduzidas na modalidade semiestruturada, por meio do uso de um questionário com perguntas fechadas e abertas, que incentivaram os entrevistados a discorrer livremente sobre diversos tópicos. Enquanto as perguntas fechadas permitiram algum grau de comparação entre as respostas fornecidas pelos entrevistados, as perguntas abertas foram utilizadas para o aprofundamento da compreensão das organizações estudadas, de forma a possibilitar a construção de registros menos lineares sobre compreensão dos entrevistados a respeito dos processos nos quais se inseriram. Participaram das entrevistas sete lideranças dos movimentos apresentados, seis dos quais estiveram ou estão no EPL.

Quadro 1 - Lista de Entrevistados e relação com as organizações estudadas

\begin{tabular}{|l|l|l|l|}
\hline \multicolumn{1}{|c|}{ Entrevistado } & \multicolumn{1}{|c|}{ EPL } & \multicolumn{1}{c|}{ MBL } & \\
\hline Entrevistado 1 & Fundador & & Fundador e Dirigente \\
\hline Entrevistado 2 & Fundador e ex-dirigente & Fundador e ex-dirigente & \\
\hline Entrevistado 3 & Fundador, ex-dirigente & Fundador & Fundador, ex-dirigente \\
\hline
\end{tabular}




\begin{tabular}{|l|l|l|l|}
\hline Entrevistado 4 & Dirigente & & \\
\hline Entrevistado 5 & Fundador e dirigente & Fundador & \\
\hline Entrevistado 6 & Dirigente & Dirigente & \\
\hline Entrevistado 7 & & & Dirigente \\
\hline
\end{tabular}

A escolha dos entrevistados foi feita pelo método "bola de neve", no qual os entrevistados indicaram lideranças centrais e responsáveis pela gestão de redes. A primeira entrevista foi com o Entrevistado 7, dada a disponibilidade do entrevistado e sua abertura para contribuir com a pesquisa.

De maneira geral, os questionários aplicados (Anexos I, II e III) tinham foco sobre quais plataformas de comunicação eram utilizadas pelas organizações estudadas, quais as finalidades desses usos e qual o grau de relevância atribuído a cada uma dessas ferramentas digitais. Além disso, foi questionado aos entrevistados se outras plataformas foram relevantes em momentos distintos, de forma a identificar ferramentas tecnológicas predecessoras e seus possíveis impactos, inclusive antes da fundação dessas organizações.

A análise das postagens publicadas nas páginas do Facebook, explicada na próxima seção, possibilitou identificar de que maneira os usos cotidianos dessa rede social respondem ao equacionamento do dilema entre coesão e expansão, demonstrando como as organizações constroem sua identidade na interação com seus públicos. Nos sítios eletrônicos oficiais, os documentos e campanhas referentes às políticas das organizações estudadas possibilitaram a compreensão de suas estruturas e históricos em um nível mais sistêmico, contribuindo para elucidar a opinião de alguns atores sobre o processo de formação de sua organização e da Rede EPL.

A análise das redes do Facebook foi construída em 3 etapas: mineração de dados, processamento de dados e formatação gráfica. A mineração de dados foi realizada em torno da rede de curtidas das 3 organizações centrais: Estudantes 
Pela Liberdade, Mercado Popular ${ }^{8}$ e Movimento Brasil Livre. Para isso usou-se a ferramenta de crawler Netvizz ${ }^{9}$, um software não-proprietário que coleta dados de páginas do Facebook (RIEDER, 2013). Na mineração dos dados, é utilizada a técnica de Snowball (BENEVENUTO, 2010), consistente na coleta de todos os nós conectados a um nó-semente, e, na sequência, todos os nós conectados àqueles mapeados na primeira busca. No presente trabalho, utilizou-se grau de profundidade 2 .

Para organizar os dados em forma de visualização gráfica foi utilizado o Gephi, outro software não-proprietário, que permite a aplicação de diversos logaritmos e técnicas para visualização gráfica. A informação foi processada utilizando os seguintes algoritmos do Gephi: 1. Modularidade - utilizada para identificação de sub-redes, por meio do número de conexões (arestas) compartilhadas entre as organizações (nós); 2. Hubs - nós que possuem centralidade no processo de conexão entre as sub-redes; e 3. Autoridade, utilizado para determinar a relevância de cada nó para a rede (CALERO VALDEZ et al., 2012). O algoritmo de organização dos nós utilizado foi o Force Atlas 2, que se utiliza de construções matemáticas baseadas na lei da gravidade ${ }^{10}$, permitindo de maneira mais ágil e simples a visualização gráfica da rede.

\subsection{Codificação das postagens}

O processo de extração de postagens das páginas do Facebook resultou em 5208 postagens do Movimento Brasil Livre, 1091 postagens do Mercado Popular e 2305 postagens do Estudantes Pela Liberdade. Apesar do grande volume de postagens do MBL, é necessário registrar que uma parte do conteúdo publicado no ano de 2014 foi retirado da página pelos administradores, refletindo a mudança de direção no movimento, ocorrida no mesmo ano - o que é explicado no terceiro capítulo. Como as postagens de usuários externos não necessariamente representam a opinião das organizações e podem estar fora

\footnotetext{
${ }^{8}$ Como a página do Mercado Popular não curtia nenhuma outra página na data da mineração de dados, tornou-se inviável a análise a partir desse nó. Entretanto, como explicado no Capítulo 4, a análise do Mercado Popular é feita a partir de sua posição na rede egocentrada do EPL.

9 A ferramenta está disponível para livre acesso em https://apps.facebook.com/netvizz/?fb source=search\&ref=ts\&fref=ts

${ }^{10}$ As informações sobre o logaritmo, suas construções e aplicações podem ser verificadas nesse arquivo: http://webatlas.fr/tempshare/ForceAtlas2 Paper.pdf
} 
de sua estratégia política, consideraram-se, na presente pesquisa, apenas as postagens feitas pelos administradores das páginas.

A extração dos dados foi realizada com o Netvizz. $O$ arquivo gerado no formato ".tab" foi convertido e reorganizado em planilha ".xlsx" utilizando Excel, para ser posteriormente importado ao Software NVIVO, conforme explicado no Anexo IV. O NVIVO foi utilizado para facilitar o processo de classificação manual do conteúdo, o que poderia ser feito com outras ferramentas, inclusive o próprio Excel.

$\mathrm{Na}$ fase de pré-análise, realizei três leituras das postagens por amostra aleatória para definir qual seria a unidade analítica, o procedimento de classificação a ser adotado e a definição das categorias mais adequadas à análise.

Optei por fazer a classificação dos dados utilizando a regra da exaustividade (BARDIN, 2009), que consiste na exploração de todas as unidades de análise disponíveis, sem qualquer seleção - o que anula a possibilidade de viés na escolha da amostra. Do mesmo modo, foi adotado o procedimento fechado de análise com o uso de técnicas taxonômicas (apud, p.125). A unidade de análise escolhida foi a postagem no Facebook.

A classificação das postagens foi feita considerando-se cinco elementos: 0 referente da mensagem; o tipo de linguagem adotada; a manifestação de pedido de recursos materiais; a explicitação do interesse em recrutar; e a mobilização para ações políticas (contenciosas ou não). Para o processo de classificação, definimos quinze categorias distintas, que buscam agregar posts com objetivos semelhantes para fins analíticos:

Quadro 2 - Estrutura de classificação das postagens

\begin{tabular}{|l|l|}
\hline Nó & Definição \\
\hline Protestos & $\begin{array}{l}\text { Postagens que contenham informações sobre ou convocatória para } \\
\text { protestos, entendidos exclusivamente como as manifestações } \\
\text { presenciais. }\end{array}$ \\
\hline Mobilização & $\begin{array}{l}\text { Postagens com chamados para ações virtuais ou outros eventos } \\
\text { presenciais que não se enquadrem na definição de protesto, tais como } \\
\text { seminários, debates, conferências e cursos de formação }\end{array}$ \\
\hline
\end{tabular}




\begin{tabular}{|c|c|}
\hline Nó & Definição \\
\hline $\begin{array}{l}\text { Recrutamento } \\
\text { Próprio }\end{array}$ & $\begin{array}{l}\text { Postagens voltados ao recrutamento de membros e colaboradores para } \\
\text { a própria organização }\end{array}$ \\
\hline $\begin{array}{l}\text { Recrutamento } \\
\text { para terceiros }\end{array}$ & $\begin{array}{l}\text { Postagens voltados ao recrutamento de membros e colaboradores para } \\
\text { organizações parceiras }\end{array}$ \\
\hline $\begin{array}{l}\text { Levantamento de } \\
\text { recursos }\end{array}$ & $\begin{array}{l}\text { Postagens voltados a arrecadar recursos financeiros e apoio material de } \\
\text { todo tipo. }\end{array}$ \\
\hline $\begin{array}{l}\text { Solidariedade } \\
\text { Nacional }\end{array}$ & $\begin{array}{l}\text { Postagens feitos para demonstrar apoio a atores sociais e políticos } \\
\text { nacionais distantes da rede dos atores, que não compartilhem os } \\
\text { mesmos espaços que a organização e sobre os quais a organização } \\
\text { não demonstre interesses de influência ou de aproximação. }\end{array}$ \\
\hline $\begin{array}{l}\text { Solidariedade } \\
\text { Transnacional }\end{array}$ & $\begin{array}{l}\text { Postagens feitos para demonstrar apoio a atores sociais e políticos } \\
\text { estrangeiros distantes da rede dos atores, que não compartilhem os } \\
\text { mesmos espaços que a organização e sobre os quais a organização } \\
\text { não demonstre interesses de influência ou de aproximação. }\end{array}$ \\
\hline Networking & $\begin{array}{l}\text { Postagens de apoio ou aproximação com organizações que estão na } \\
\text { esfera de influência dos atores estudados ou com os quais os atores } \\
\text { mantenha relações políticas. }\end{array}$ \\
\hline Agitação & $\begin{array}{l}\text { Postagens de autoafirmação, com objetivo de promover a organização } \\
\text { ou o campo político de que fazem parte as organizações estudadas. } \\
\text { Possui conteúdo que exalta a organização/rede e busca promovê-la ao } \\
\text { público. }\end{array}$ \\
\hline Demarcação & $\begin{array}{l}\text { Postagens voltados à diferenciação e delimitação política em relação } \\
\text { aos atores que também se identifiquem no campo da direita. Tem por } \\
\text { objetivo a distinção identitária, sem qualquer chamado para ação }\end{array}$ \\
\hline $\begin{array}{l}\text { Crítica Anti- } \\
\text { petista }\end{array}$ & $\begin{array}{l}\text { Postagens voltados à construção de críticas ao PT ou ao governo do PT } \\
\text { sem qualquer outro conteúdo objetivo de ação. }\end{array}$ \\
\hline Crítica outros & $\begin{array}{l}\text { críticas dirigidas a outros atores de esquerda que não estejam nop } \\
\text { definição campo governista, compondo a oposição de esquerda e grupo } \\
\text { autônomos ou que sejam de outros países. }\end{array}$ \\
\hline Debate Público & $\begin{array}{l}\text { Postagens voltados ao debate sobre formulações teóricas e políticas. } \\
\text { Deve conter linguagem que expresse abertura ao debate, respeito com } \\
\text { os interlocutores e o objeto do post. Pode se dirigir tanto ao próprio } \\
\text { campo, quanto a atores de outros campos políticos. }\end{array}$ \\
\hline Indisponível & $\begin{array}{l}\text { Informação não disponível por corrupção nos dados - link não funciona, } \\
\text { meme retirado, vídeo indisponível, etc. }\end{array}$ \\
\hline
\end{tabular}




\begin{tabular}{|l|l|}
\hline Nó & Definição \\
\hline Outros & $\begin{array}{l}\text { Postagens que não se enquadrem em nenhuma das outras categorias } \\
\text { citadas. }\end{array}$ \\
\hline
\end{tabular}

\subsubsection{A aplicação}

A primeira preocupação no processo de classificação dos dados foi evitar um viés de confirmação, que, de acordo com Nickerson (1998), "conota uma menos explícita e menos consciente construção tendenciosa de caso, [...] referindo-se usualmente à uma seletividade inconsciente na aquisição e uso das evidências". Assim, optei por incluir um colaborador na execução dessa tarefa, que estava desinformado das expectativas do autor sobre o comportamento esperado de cada organização, desvinculado das organizações estudadas, mas instruído sobre o perfil e as conexões de cada uma delas para proceder adequadamente ao processo de análise ${ }^{11}$.

Esse cuidado de delegar uma parte do processo de classificação a um terceiro complementa a decisão explicitada anteriormente de não se fazer qualquer tipo de recorte amostral nos dados extraídos para evitar um viés analítico. Num primeiro momento, a codificação de uma pequena quantidade de dados foi feita em conjunto pelo autor dessa dissertação com o colaborador externo. Em seguida, a análise foi inteiramente realizada pelo colaborador que enviou os dados em três blocos - dividido por organização - para análise do autor. Os dados foram então checados e eventuais erros de codificação - como duplicidade ou ausência - foram corrigidos.

Cada postagem só pôde ser classificada em um nó. Para os casos passíveis de classificação em mais de um nó, foram estabelecidos alguns critérios para resolução da sobreposição:

A) o nó protesto tem prevalência sobre todos os demais, dada a centralidade das ações contenciosas como repertório de ação, seguido, por recrutamento próprio,

\footnotetext{
${ }^{11}$ Agradeço ao lan Viana, estudante de graduação do curso de Sociologia da Universidade de Brasília, pela dedicada contribuição a essa pesquisa na classificação das postagens.
} 
levantamento de recursos e networking, na ordem, sem hierarquia entre os demais;

B) as postagens com conteúdo programático que possuírem linguagem agressiva, irônica ou sarcástica perdem a caracterização de debate público pela forma de sua expressão, transformando-se em crítica ou demarcação, a depender do ator a que se dirigir;

C) postagens com conteúdo tanto crítico quanto demarcatório são caracterizadas, por exclusão semântica, como postagens de agitação, pois a desconstrução simultânea de atores à direita e à esquerda representa o interesse da organização em se promover como alternativa, o que é um ato agitatório.

D) nos casos de postagens que possuam conteúdo de agitação combinado com crítica ou demarcação, deve prevalecer o nó mais evidenciado ao longo do conteúdo; e

E) os casos omissos ou complicados são classificados em "Outros".

Por fim, cabe uma breve observação sobre a dificuldade de se aplicar codificação automática com base em Linguagem Natural ${ }^{12}$ para o caso estudado. Como a análise realizada necessita da capacidade de identificar ironia, sarcasmo e outras figuras de linguagens, a utilização de ferramentas de análise de linguagem natural, considerando os meios e codificações disponíveis até o momento, sujeitaria o trabalho a alta taxa de erro. Além disso, há um grande número de imagens e vídeos no universo de postagens analisadas, o que complica ainda mais o processo analítico.

\footnotetext{
12 Linguagem natural é um campo dentro da área de Inteligência Artificial que estuda as interações homens máquina, desenvolvendo a capacidade de computadores identificarem sentidos na fala humana.
} 


\section{Internet e Movimentos Sociais}

Desde o final dos anos 1980, e principalmente a partir da década de 1990, diversos autores se dedicaram a estudar como a internet impactaria os movimentos sociais, inclusive com a construção de prognósticos. Entre os primeiros estudos empíricos sobre a apropriação das plataformas digitais por movimentos sociais, está o trabalho de Downing (1989) sobre a Peacenet - uma rede de militantes pacifistas fundada em 1986 por iniciativa de quatro organizações norte-americanas, que conseguiu, ainda em 1988, nos primórdios da internet, congregar mais de 2000 usuários - e sobre o Public Data Access (PDA) - uma iniciativa de ativismo hacker que buscava analisar e tornar grandes bases de dados acessíveis ao público.

Downing (1989, p. 162) defendeu o potencial positivo do uso dos computadores e da internet no fortalecimento de movimentos sociais e da democracia, destacando as possibilidades que se abriam para a coleta e análise de dados, para a mobilização de ativistas separados pelo espaço e tempo, para a formação de fóruns com capacidade de desenvolver narrativas e agendas de ação política e para conectar pessoas além das fronteiras nacionais na discussão dos problemas comuns a toda a humanidade, fortalecendo os acúmulos e recursos da cultura democrática.

Nos anos 1990, inúmeros trabalhos sobre o uso da internet na formação de uma rede internacional de solidariedade ao movimento zapatista (CLEAVER JR., 1998; FROEHLING, 1997; RONFELDT et al., 1998) destacaram como a visibilidade sobre o conflito político do México a partir da internet foi importante para mobilizar diversos atores nacionais e internacionais para constranger e pressionar o Governo Mexicano, aumentando os custos de ações violentas por parte do Estado.

Para o melhor desenvolvimento do marco teórico que referencia essa dissertação, realizo nas seções seguintes deste capítulo quatro debates centrais para a compreensão da relação entre movimentos sociais e redes sociais virtuais. A primeira seção, em referência à literatura sobre repertórios de ação coletiva, aborda uma parte dos trabalhos publicados sobre as oportunidades e desafios organizacionais que são criados com a disseminação das ferramentas 
digitais. A segunda seção trata das obras que dialogam com as novas lógicas de organização que surgem a partir da internet, seus impactos sobre as redes e sobre a organização dos movimentos sociais. A terceira aborda os trabalhos que tratam de mecanismos, processo político e dos comportamentos sociais associados à disseminação das ferramentas digitais. Por último, a quarta seção busca, em uma perspectiva que mobiliza os três debates anteriores, entender de que maneira se dá a formação de identidades nos espaços digitais. Nessa última seção, abordo como os atores agem estrategicamente para a ampliação de seus recursos organizacionais e como constroem suas identidades por meio do uso dessas novas ferramentas.

\subsection{Redes Sociais como recurso: desafios e oportunidades}

As potencialidades das redes sociais virtuais são largamente exploradas na literatura recente sobre movimentos sociais. De acordo com Mário Diani (DIANI, 2000), algumas das vantagens potenciais da "Comunicação Mediada por Computador" são os reduzidos custos de comunicação mesmo entre atores separados por grande distância; a acurácia da mensagem original; o potencial de promover interação entre agremiações ou células de organizações e ativistas de movimentos; e a oportunidade de transformar grupos de indivíduos geograficamente dispersos em uma população de descontentes densamente conectada ${ }^{13}$.

Há também um vasto registro na literatura sobre o uso das redes sociais virtuais, em especial Twitter e Facebook, como ferramenta de mobilização e/ou coordenação para protestos e outras ações contenciosas (ver BRUNS; HIGHFIELD; BURGESS, 2014; DELLA PORTA, 2011; GARCÍA et al., 2014; GERBAUDO, 2012; VALENZUELA; ARRIAGADA; SCHERMAN, 2013; VALENZUELA, 2013; ZHU, 2015). De acordo com Carothers e Youngs (CAROTHERS; YOUNGS, 2015), essa facilidade trazida pelas redes sociais

\footnotetext{
${ }^{13}$ Diani (2000, p.393), entretanto, observa que a ausência de contato físico e a natureza da interação digital implicam em dificuldades para a ação coletiva. Por fim, ele afirma que o impacto democratizante das plataformas digitais seria fortemente mitigado por dois tipos de restrições: enquanto a contribuição das plataformas digitais para conectar cidadãos seja inegável, as suas contribuições para as operações de controle sociais por agente públicos e corporações é mais muito maior; além disso, o acesso às plataformas digitais permanecia correlacionado com classe e status.
} 
para a organização coletiva é um possível fator explicativo da multiplicação no número de protestos ocorridos a partir de 2010 e do fortalecimento das oposições em países autoritários.

Além disso, as redes sociais e outras ferramentas online têm sido utilizadas para o recrutamento de pessoas (NIELSEN, 2011b; THEOCHARIS et al., 2013; VISSERS; STOLLE, 2014), para o levantamento de doações financeiras, por meio de ferramentas como crowdfunding (BIMBER; JORBA, 2010; COSTANZACHOCK, 2003; GARRET, 2006; HOWARD, 2005; MEGAN BOLER, 2008), e para construção colaborativa de ações militantes (BENNETT; SEGERBERG; WALKER, 2014; GARRET, 2006; ILTEN, 2015; MERCEA, 2013; REGATTIERI et al., 2014).

A disputa política direta na internet também se dá por meio da busca de apoio da opinião pública em ações dos movimentos sociais (Schulz, 1998; Keck and Sikkink, 1998; Kumar, 2000 apud COSTANZA-CHOCK, 2003). Nesse tipo de engajamento virtual, as plataformas digitais se apresentam como espaços de construção de legitimidade nos quais os movimentos sociais podem dialogar diretamente com a sociedade, trazer suas versões sobre os acontecimentos políticos e buscar apoio público.

Para além de poder servir como instrumento de organização e mobilização em atos convencionais, a internet também cria novos repertórios de ação, tais como curtir, seguir e "ser amigo" de um político ou organização, atos que pouco se vinculam com as categorias de ação tradicionais (BIMBER; JORBA, 2010). Esses novos repertórios são também formas de expressar apoio e afirmar identidade política que se caracterizam pelo baixíssimo custo de transação podem ser concretizados em poucos segundos, possibilitando expressão política mesmo a quem tem pouco interesse ou condições de participar de ações que exijam maior esforço, engajamento e disponibilidade. A essa categoria de novos repertórios, Van Laer e Van Aelst (2010) adicionam os conceitos de bombardeamento de e-mails ${ }^{14}$ e ocupações virtuais ${ }^{15}$, além de destacar as

${ }^{14}$ Conhecida por email bomboing ou email flooding - essa tática consiste no envio massivo de mensagens eletrônicas para lotar uma caixa de entrada de correio eletrônico.

15 Tradução livre nossa para o termo virtual sit-in - que significa o ato de deliberadamente sobrecarregar um servidor para derrubar a página ou impedir que outras pessoas a acessem. 
petições online, como um repertório significativamente inovador em relação àquele que lhe deu origem.

Numa tentativa de sistematizar os diversos repertórios disponíveis, CostanzaChock (2003) desenvolve o conceito de Desobediência Civil Eletrônica como uma subcategoria do que denomina repertórios de conflito eletrônico. Dentro dessa categoria, o autor lista diversas ações possíveis, como forms flooding ${ }^{16}$, Denial Of Service (DOS) ${ }^{17}$, alteração ou direcionamento de sítios eletrônicos e disseminação de vírus, worms e cavalos de tróia. Van Laer e Van Aelst (2010, p. 1158-1159) descrevem ainda a utilização de um conjunto de ações que denominam intervenção cultural $^{18}$, consistente no uso de técnicas como apropriação, colagem, inversão irônica, paródias, paráfrases, e justaposição para atacar os símbolos culturais de seus opositores, por meio do poder do humor, da sátira e da ironia.

Além das potencialidades que as ferramentas digitais apresentam, diversos autores também chamam atenção para os riscos que as acompanham. Elas podem ser utilizadas como instrumentos de controle social tanto por governos, como por agentes privados detentores da infraestrutura digital. Esse controle pode assumir a forma de vigilantismo e censura sobre movimentos sociais (DEIBERT, 2008; MOROZOV, 2011) ou de violação da privacidade e direcionamento de conteúdo voltados à exploração de mercado (RAINIE; WELLMAN, 2012). A internet também é um ambiente que facilita a disseminação de notícias falsas (DELLA PORTA; MOSCA, 2005), o que pode ser usado como ferramenta de desinformação para confundir os movimentos sociais ou com 0 objetivo de difamá-los. Morozov (2011) alerta ainda que os governos e grupos autoritários podem usar as redes sociais e novas tecnologias para contrapropaganda.

A sujeição aos ônus da tecnologia é, em parte, inescapável. Se a não-utilização das redes sociais virtuais pode ser uma forma de tentar reduzir a sujeição ao

\footnotetext{
16 Prática que consiste no preenchimento automático e repetitivo de formulários em sítios eletrônicos com o objetivo de inviabilizar o acesso público à página web boicotada.

17 DOS consiste na indisponibilização de websites por meio de diversas técnicas de sobrecarga dos servidores, inclusive virtual sit-in e form flooding.

18 Tradução livre nossa para o termo Culture jamming
} 
controle estatal, ela jamais eliminaria dos movimentos o ônus de terem de se contrapor às difamações ou de arcar com as consequências das ações virtuais de deslegitimação que sofrerem. Ainda, a utilização de criptografia no envio de mensagem e o uso de sistemas de comunicação direta (peer-to-peer) representam alternativas muito menos suscetíveis ao controle de agentes públicos e órgãos de espionagem do que a utilização da rede de telefonia ${ }^{19}$.

Adicionalmente, o crime organizado também está presente na internet e fazendo largo uso das ferramentas digitais (FARRELL, 2012). Costanza-Chock (2003) cita a possibilidade de atos de ciberterrorismo, o qual define como "danos físicos causado a humanos por meio da perturbação de sistemas de distribuição de energia, água, controle de tráfego aéreo e etc". Nesse sentido, o fato de grupos criminosos estarem presentes nos espaços virtuais fortalece os argumentos para que os governos elevem o grau de vigilantismo sobre a comunicação digital.

Como resumem Della Porta e Mosca (2005), a internet e suas ferramentas representam tanto oportunidades como desafio aos movimentos sociais. Estar alienado dessa realidade, entretanto, significa não ter acesso à maior parte dos benefícios que ela traz, além de não eliminar a sujeição a boa parte de seus ônus.

\subsection{Internet e novas formas de organização}

Há um debate intenso entre os pesquisadores do campo de movimentos sociais sobre como a internet altera a lógica de organização e participação nos coletivos políticos. Para Castells (2009), a internet cria poderosos instrumentos de autocomunicação de massas, que estendem a fronteira de possibilidades para a organização coletiva e que acarretarão em mudança social - o que autor afirma que acontecerá certamente, mas sem definir o objeto e conteúdo dessa mudança.

19 Para mais informações a respeito, ver Post-Snowden Cryptography https://hyperelliptic.org/PSC/; How cryptography is a key weapon against empire states http://www.theguardian.com/commentisfree/2013/jul/09/cryptography-weapon-fight-empire-

states-julian-assange; Snowden's Crypto Software may be tainted forever http://www.wired.com/2014/05/truecrypt/ acessados em 22/01/2016. 
Para Bennett e Segerberg (2012), as redes sociais e outras ferramentas da internet criam uma nova lógica de organização, a qual denominam de ação conectiva, que se distingue da lógica da ação coletiva. Para esses autores, as redes organizadas sob a lógica da ação conectiva ${ }^{20}$ podem ser de dois tipos: auto-organizada - em que os atores institucionais estão na periferia da rede e não há coordenação organizacional - e as ativadas por organizações - em que as organizações fazem uma coordenação mais solta e buscam fomentar 0 ativismo individual, com algum grau de moderação. Nessa linha, o primeiro tipo de ação conectiva permite que os indivíduos se organizem de maneira efetiva e com autonomia em relação a coletivos políticos, enquanto o segundo possibilita uma nova forma de esses coletivos mobilizarem ativistas para suas atividades. Nos dois casos, utilizam-se formas associativas mais livres e as ações são apropriadas pelos indivíduos por meio de "enquadramentos de ação personalizáveis" ${ }^{\prime 1}$, diferentemente do que ocorre na lógica de ação coletiva.

Os pressupostos e achados de Bennett e Segerberg não passam incólume a críticas. Para Tarrow (2014), há dois problemas na construção dos autores: a) eles caricaturizam a lógica da ação coletiva, reduzindo-a à escola racionalista olsoniona, razão pela qual esconderiam que o que eles denominam de "quadros de ação personalizados" já são largamente evidenciados na literatura como parte do repertório tradicional de movimentos sociais e portanto não representam nenhum diferencial em relação à lógica da ação coletiva; e b) tratam da anomia - o afastamento dos indivíduos das estruturas sociais integrativas - como algo novo e positivo, mas não abordam o impacto das tecnologias digitais para a organização dos movimentos sociais. Tarrow conclui que os autores deveriam dar mais atenção ao papel da linguagem na comunicação digital.

Para Gerbaudo (2014), o trabalho de Bennett e Segerberg falha por tratar a internet não apenas como uma variável independente da qual todas as outras dependem, mas como a única capaz de unir indivíduos egoístas; por não analisar como se dá o processo de formação de identidade coletiva nos espaços digitais, ignorando o papel da cultura e da identidade nos protestos; e por negligenciar o

\footnotetext{
20 Os autores constroem três tipos ideais: um referente à ação coletiva e dois referentes à ação conectiva.

${ }^{21}$ Tradução livre para personalized action frames.
} 
papel das lideranças, ignorando que novas formas de lideranças emergem nesses espaços.

Por outro lado, Gerbaudo concorda com Bennett e Segerberg sobre o caráter cada vez mais personalizado dos protestos e do crescente descrédito das instituições tradicionais, mas ressalta que isso não significa o fim das identidades coletivas, senão o surgimento da demanda por novas identidades, em que as mídias sociais são apenas o trampolim para um processo de recomposição social e física. Nesse sentido, Nielsen (2011b), na mesma linha de Castells (2009), afirma que o potencial de mobilização das ferramentas digitais permanecerá apenas como um potencial se não houver interesse e capacidade de serem apropriadas pelos movimentos sociais. Esse é um ponto de tensão entre os trabalhos que tratam as redes sociais como variáveis independentes e os que as identificam como ferramentas com profundo impacto sobre os movimentos sociais. Entre os trabalhos do primeiro grupo, há uma crença de que a democratização virá de maneira quase automática, graças às capacidades sociais da tecnologia. No segundo, há a perspectiva de que o uso dessas ferramentas está sujeito a um processo dialógico, em que agente e objeto se modificam mutuamente.

Carla Ilten (2015), ao analisar uma plataforma virtual de gerenciamento de microvoluntariado chamada Sparked, afirma que a lógica de funcionamento dessa plataforma teria a capacidade de reorganizar a relação entre voluntários e organizações, de maneira a manter os voluntários ligados à plataforma e não às organizações que ajudarem. Dessa maneira, os voluntários adeririam a um projeto com o qual tivessem afinidade, mas não à organização. Isso, de acordo com a autora, representa um grau de racionalização no processo de alocação dos voluntários que os garante maior discrição, permite mais individualização na forma de envolvimento e reduz o comprometimento com a organização. Isto também representa um enfraquecimento no processo de formação de identidade.

Em um estudo sobre os impactos do Facebook na organização de dois acampamentos de protestos, Dan Mercea (2013) afirma que esta mídia social galvanizou a auto-organização de grupos e indivíduos, provendo-os com os 
meios para coordenarem-se autonomamente, para decidirem com independência sobre os parâmetros de sua participação e para informalmente entrar na rede fluida de grupos variados que coletivamente formaram os dois acampamentos. Sobre o processo decisório, entretanto, Mercea (2013) conclui ter sido difícil observar como a colaboração nos grupos dos dois acampamentos no Facebook se traduziria em mudanças na forma organizacional que implicassem o processo decisório.

Van Laer e Van Aelst (2010) afirmam que a internet é especialmente útil nos esforços de grupos e organizações para coordenarem-se e para integrar outros participantes nas ações de protesto. Adicionalmente, eles concluem que a internet traz mais vantagens organizacionais para os pequenos grupos e para os movimentos sociais - visto terem uma forma de organização mais horizontal, concluindo que para os grandes grupos ou para as organizações mais hierarquizadas e formais, a internet representa mais ameaças e menos oportunidades.

O que os quatro trabalhos (BENNETT; SEGERBERG, 2012; ILTEN, 2015; MERCEA, 2013; VAN LAER; VAN AELST, 2010) apontam em comum é o crescimento de uma lógica comunicacional mais fluida nas relações entre os movimentos e seus públicos - audiência, participantes internos, colaboradores eventuais e potenciais apoiadores. Nesse mesmo sentido, os trabalhos argumentam que nem todas as organizações políticas conseguem auferir os ganhos dessa fluidez. Para que isso ocorra, há o pressuposto de que esses movimentos se adequem à lógica das redes sociais virtuais e ofereçam formas de participação mais personalizadas e livres. Outro achado comum aos autores - com exceção de Carla Ilten, por não abordar esse tema - é que as ferramentas digitais também facilitam o diálogo entres os participantes individuais e coletivos na organização de protestos. Todas essas possibilidades de abertura e ampliação democrática, entretanto, só são observadas em grupos que já possuem pré-disposição a formas mais livres e horizontais de organização. Nesse sentido, é possível concluir que as redes sociais virtuais têm o potencial de gerar formas de interação mais horizontais, mas não necessariamente implicam em mudança no processo decisório e na formulação das diretrizes políticas, a não ser nos casos em que essa abertura fosse buscada pela 
organização. Ou seja, as plataformas digitais não foram causa de maior horizontalidade, mas mera ferramenta que deu materialidade ao desejo da organização.

\subsection{Internet, engajamento político e desigualdades}

De acordo com Gil de Zuniga (2015), a internet e as redes sociais digitais alteraram a realidade política, revigorando a maneira como as pessoas discutem e expressam seus pensamentos, afetando o engajamento em atividades políticas e impactando também a maneira com que os cidadãos se relacionam entre si e com seus governos, desenhando uma nova "esfera pública". O conteúdo dessas mudanças, entretanto, está longe de ser objeto de consenso.

Uma das características mais exploradas na literatura sobre engajamento político e internet é a maneira pela qual a lógica do mundo digital reforça a homofilia - a propensão de indivíduos com características ou preferências semelhantes a se agruparem (FARRELL, 2012). Crandall et al (2008) demonstram que se a semelhança causa interação social no mundo virtual, a interação social também tem como resultado 0 aprofundamento das semelhanças entre os indivíduos de um determinado grupo ou espaço de convívio virtual. Essa constatação dos autores revela um processo de criação e fortalecimento de identidades a partir do espaço virtual, numa dinâmica em que indivíduos se reconhecem mutuamente ao se atribuírem valores, símbolos, tradições e outras características físicas, comportamentais e ideológicas pelos quais se afirmam enquanto coletivo. As ferramentas digitais fazem ser muito mais provável que indivíduos com interesses pouco usuais ou características raras se encontrem, formando grupos e se organizando na defesa de seus interesses comuns (FARRELL, 2012).

Algumas características das ferramentas digitais - como o relativo anonimato, 0 menor risco de violência física e a facilidade de conectar pessoas com interesses, valores e crenças comuns - podem aumentar a propensão dos indivíduos a se expressarem (FARRELL, 2012). O fato de o ambiente virtual não ser afetado por interações físicas e pela comunicação não-verbal facilita a formação de relações em bases cognitivas mais profundas, como valores e 
crenças compartilhadas (BARGH; MCKENNA, 2004), fortalecendo os laços fracos. Galacz e Smahel (2008) apontam que, entre aqueles descontentes com a maneira com que a família discute assuntos comuns, a internet serve como importante instrumento para as pessoas se comunicarem com outros indivíduos com os quais possuam mais afinidade, afastando-se do círculo familiar. Os estudos dos autores não apontam, entretanto, maior interação virtual entre aqueles indivíduos que não estão descontentes com a maneira com que sua família discute assuntos comuns.

Conforme indica Farrell (2012), a internet diminui o fenômeno da falsificação de preferências ao reduzir o custo de um indivíduo revelar as verdadeiras preferências, pois sem as barreiras geográficas das comunidades, o espectro político é ampliado, facilitando que indivíduos com preferências minoritárias se expressem e possibilitando que encontrem outras pessoas com quem possam compartilhar suas verdadeiras crenças.

As observações que apontam para o fortalecimento da homofilia geram a expectativa de que se forme um processo intenso de isolamento entre grupos com preferências políticas diferentes, que impactará profundamente o tecido social (BIMBER; JORBA, 2010; FARRELL, 2012; MOROZOV, 2011). Entretanto, conforme afirmam Wojcieszak e Mutz (2009), há um problema a respeito da forma com que os pesquisadores tentam aferir o contato com a divergência, já que os indivíduos têm maior contato com diversidade política nos espaços das redes virtuais não tradicionalmente devotados a temas políticos, da mesma maneira como ocorre nas redes sociais físicas, em que as pessoas estão mais sujeitas ao debate com a diferença nos espaços familiares, no clube, no trabalho e na escola do que nos coletivos ou espaços dedicados a política - nos quais ela se agrupam por afinidade.

Outro ponto relevante nos trabalhos sobre internet e política diz respeito ao impacto que as novas tecnologias de comunicação teriam sobre o grau de participação política da sociedade. Evidências sugerem que há uma associação positiva entre o uso de mídias digitais e o fortalecimento de outras formas de participação (BARGH; MCKENNA, 2004; BIMBER; JORBA, 2010; OLORUNNISOLA; MARTIN, 2013; VALENZUELA; ARRIAGADA; SCHERMAN, 
2013) - o que inclui engajamento cívico, construção de conhecimento, plataformas de doações, formação de grupos de interesses, de discussão e conversação política, além de participação em eventos políticos, em atividades chamadas por grupos de interesse e em interação com o governo (BIMBER; JORBA, 2010).

Baumgartner e Morris (2010), por outro lado, enfatizam que não há unanimidade nesse sentido. Ao estudar a correlação entre consumo de notícias em redes sociais virtuais e participação, os autores afirmam que o potencial para aumentar o engajamento político de jovens adultos não se concretiza. Há que se ressaltar, entretanto, que, nesse estudo, os autores consideraram como medida de participação exclusivamente o voto nas eleições norte-americanas de 2008 - um parâmetro muito restrito e pouco relacionado a formas mais ativas de participação. Ao final do artigo, os autores reconhecem ainda que as redes sociais virtuais são utilizadas com sucesso para mobilizar apoiadores e realizar levantamento de fundos para as campanhas - o que implica em aceitar que mesmo não ampliando o comparecimento às eleições de 2008 , as redes sociais virtuais foram fundamentais para fortalecer a participação de indivíduos nas campanhas eleitorais. Pesquisas recentes em participação política indicam que, enquanto algumas formas mais convencionais de participação - como o voto e as atividades partidárias - estão decrescendo, os protestos têm ampliado (DELLA PORTA, 2011).

Além da discussão sobre "se" e "como" a internet aumenta ou reduz a participação política, é fundamental compreender em que sentido ela altera a balança de poder, identificando os possíveis beneficiados e prejudicados com o uso das novas tecnologias. O debate sobre a lacuna digital traz indícios de que os impactos da internet podem ampliar uma série de desigualdades sociais. Essa desigualdade confere bastante poder a quem controla a infraestrutura física da internet e as plataformas digitais (DEIBERT, 2009; MOROZOV, 2011; PHILLIPS, 2009), a quem possui os meios materiais para ter acesso à internet (HARGITTAI, 2001; MORRIS; MORRIS, 2013; NORRIS, 2001), a quem domina a gramática das tecnologias digitais (DIMAGGIO et al., 2001; HARGITTAI, 2001) e a quem possui o capital simbólico e cultural para a construção de narrativas e para a 
influência nas esferas públicas criadas no espaço digital (MORRIS; MORRIS, 2013).

Como definido por Dimaggio et al. (2001, p. 310), o conceito de lacuna digital refere-se às desigualdades no acesso à internet, à extensão do uso, ao conhecimento sobre as estratégias de busca, à qualidade da conexão técnica e do suporte social, à habilidade para avaliar a qualidade da informação e à diversidade de usos. A esses elementos adiciono o domínio da infraestrutura e o controle das plataformas como mais um elemento da lacuna digital, a separar o conjunto de atores que detêm a materialidade (infraestrutura) da rede, que definem as regras de uso ou que controlam os fluxos de informações daqueles que estão apenas sujeitos a esse domínio.

Como afirma Norris (2001), a lacuna digital não opera apenas entre países com mais e menos recursos, mas também internamente nas nações ricas, penalizando os que não possuem acesso a recursos econômicos e culturais. Nesse mesmo sentido, Valenzuela (2013) alerta sobre o risco de se ampliar a desigualdade, em uma tendência dos usuários de mídias sociais a se inclinarem em favor dos outros usuários que possuem maior conhecimento tecnológico e maior capital humano, social e econômico.

Dessa maneira, se a internet tem como efeito a ampliação da participação social de diversas maneiras, ela também amplia as desigualdades entre quem participa e quem não participa. Isso é importante também para se compreender a natureza da audiência e do público mais influente dentro das redes sociais digitais, minimizando uma expectativa por democratização como mera consequência de um determinismo digital. Os efeitos da tecnologia, como já afirmado anteriormente, dependem em larga escala dos usos que dela serão feitos.

\subsection{Identidade Coletiva na Era Digital}

Explorar identidade não é uma tarefa simples e requer uma constante verificação com as instâncias multifacetadas do campo empírico (MURRU, 2009). O desafio de se explorar a empiria, entretanto, é central ao avanço na compreensão sobre como as ferramentas digitais impactam na atuação, na concepção e no reconhecimento dos movimentos sociais. 
Como explica Melucci (1989, p. 34), identidade coletiva é dinâmica e compartilhada, produzida pela interação de diversos indivíduos, preocupados com a orientação de suas ações e com o campo de oportunidades e restrições que as envolve. Nesse sentido, ela deve ser compreendida como algo em constante negociação, com base em definições cognitivas sobre fins, meios e campo de ação; em processos comunicativos dados pelo relacionamento ativo entre atores; e em um grau de investimento emocional que permite ao indivíduo se sentir parte de uma unidade comum (MELUCCI, 1996). Assim, o conceito de identidade coletiva ajuda a compreender melhor as motivações e obrigações que persuadem as pessoas a se mobilizarem do que a análise utilitarista, restrita a incentivos materiais (POLLETTA; JASPER, 2001).

Para Diani (2000), a comunicação mediada por computador deve fortalecer identidade e solidariedade entre membros - de redes de advocacy - ao aumentar a taxa de intercâmbio entre organizações e ativistas geograficamente distantes. Contudo, ele também afirma que os movimentos mais participatórios, especialmente os mais radicais, dependem diretamente de interações físicas, tanto para o propósito de recrutar membros, quanto para o de assegurar seu compromisso com o movimento (DIANI, 2000, p. 397). Nessa perspectiva, dificilmente é possível pensar na construção de identidade coletiva por meio exclusivamente da interação virtual.

Talvez por essa razão, conforme reforçam Gerbaudo e Treré (2015), o conceito de identidade coletiva tenha sido pouco explorado nos estudos dominantes sobre as transformações da sociedade e de movimentos sociais resultantes da difusão das tecnologias digitais. Em outro texto, Gerbaudo (2014) reforça a necessidade de investigar os aspectos relacionados a cultura e identidade nas plataformas digitais, evitando ater-se a questões meramente técnicas que correm o risco de reduzir os movimentos a suas infraestruturas, uma vez que a importância da tecnologia se dá pela medida em que é apropriada pelos atores do movimentos, atribuindo-Ihes significados e usos.

Alguns autores -como Castells, Wellman, Haythornwaite, Vissers e Stolle - têm se dedicado a estudar em que medida a internet pode ou não ser associada a um processo de fragmentação identitária e de fortalecimento do individualismo. 
Ao apontar a redução do engajamento nas formas tradicionais de participação, Vissers e Stolle (2014) argumentam que a natureza da participação política é que está em transformação: com as instituições em crise e novos tipos de repertório ascendendo, como "lifestyle politics", consumismo político e ativismo de internet. Esse processo de fortalecimento do individualismo seria, então, um fenômeno que se observa concomitante à crise nas instituições.

Wellman e Haythornwaite (2002, p. xxxi) e Castells (2009, p. 388) argumentam, nesse mesmo sentido, que o agravamento da crise de legitimidade das instituições deve ser creditado à política do escândalo, à política midiática e ao avanço da corrupção nas instituições, mas não à internet. O que Wellman e Haythornthwaite alertam, entretanto, é que a internet pode agravar a crise de legitimidade da democracia por possibilitar novas formas de conexão fora do domínio institucional. Em suma, a comunicação virtual da sociedade em rede e a produção descentralizada de informação combinadas com a percepção das pessoas sobre as incapacidades das estruturas de poder constituídas de responder a seus anseios aumentam o grau de participação fora dos espaços políticos tradicionais.

Assim, os movimentos sociais que buscam mobilizar e se fortalecer por meio das plataformas digitais encontram-se diante da tarefa de tentar oferecer novas identidades baseadas em gramáticas políticas que pareçam diferentes das formas institucionais desacreditadas. Esse esforço se combina à necessidade de criar coalizões e formar identidades mais amplas, disputando o controle de organizações, eliminando agendas rivais, criando expressões de apoio unificado para seus próprios programas e negociando com autoridades (TARROW; TILLY; MCADAM, 2009).

Assim, em busca de dar resposta à demanda por formas de ações mais individuais e personalizáveis, as organizações políticas enfrentam um dilema: para conseguir expandir, precisam de formas mais flexíveis de participação, mais facilmente apropriáveis pelo público e cujos requisitos para adesão sejam mais frouxos (BENNETT; SEGERBERG, 2012), mas para conseguir ter mais comprometimento e unidade na ação - o que representa mais efetividade na mobilização política, a organização precisa aumentar o controle sobre a 
identidade e a ação política. Este é o dilema entre coesão - tomada como o fortalecimento da definição e do compromisso identitário - e expansão compreendida como a flexibilização da definição e do compromisso identitário para permitir alcançar um maior número de indivíduos.

Conforme afirma Tarrow (2009), o poder de acionar sequências de ação coletiva não é o mesmo que o poder para controlar ou mantê-las. Esta constatação a respeito da ausência de poder do movimento sobre seus integrantes deve ser relativizada pelos diferentes graus de influência que o movimento pode exercer.

O dilema entre coesão e expansão é adaptado a partir de outro dilema formulado por von Bülow (2016) entre a necessidade de manter maior controle sobre as concepções e as decisões a respeito de estratégia, mas ao mesmo tempo obter o máximo de benefícios possíveis dos usos da internet. A adaptação se deve ao enfoque específico desse trabalho em identidade coletiva.

A diferença fundamental entre as duas definições é que o dilema de von Bülow se desenvolve sobre as dimensões de agência e liderança nas disputas políticas, enquanto o dilema entre coesão e controle enfoca o processo de construção de identidade.

A primeira opção desenvolve, assim, o debate sobre o acesso a processos decisórios e sobre as disputas internas de poder. Está diretamente ligada a questões sobre a intensificação da capacidade dirigente das lideranças e a busca por domínio, em contraposição à possibilidade de se expandir e auferir os benefícios que trazem as plataformas digitais, que, ao final, pode significar a perda de controle sobre o processo político.

O segundo dilema, que proponho, se dá sobre a construção de narrativas dos movimentos para se legitimarem externamente e sobre sua capacidade de mobilizar e se manterem relevantes ao longo do tempo diante das mudanças nas oportunidades e restrições políticas. Se suas concepções identitárias forem mais flexíveis e abertas - o que pode ser aferido pelo teor e forma da comunicação nas mídias digitais -, poderão mobilizar um público maior, mas terão menor coesão identitária. Tendo mais dificuldade para manterem coesão identitária, estarão trabalhando com uma base composta por indivíduos soltos, fracamente 
conectados e, por isso, com baixo grau de comprometimento e unidade com a organização.

Ainda sobre o dilema entre coesão e expansão, cabe ressaltar que as organizações constroem estratégias de ação que variam ao longo do tempo, a depender do tamanho da base que construíram e da mudança na estrutura de oportunidades políticas. Conforme abordo no quarto capítulo, a decisão sobre privilegiar expansão ou controle está diretamente associada ao objetivo de cada organização política e é um processo dinâmico que responde aos fatores ambientais, à conjuntura política e às apostas dos dirigentes.

Nesse sentido, assumo que "identidade tende a coincidir com o processo consciente de organização e que sua experiência não é tanto uma situação como é uma ação", sendo concebida "como um sistema de relações e representações", que possui um "sistema de vetores em tensão (...) que busca estabelecer um equilíbrio entre os vários eixos da ação coletiva e entre a identificação declarada pelo ator e a identificação dada pelo resto da sociedade - adversários, aliados e terceiros" (MELUCCI, 1996). A multicausalidade e a interatividade que definem o processo de identidade implicam que ela não esteja sob pleno controle das lideranças, dada a existência de muitos vetores relativamente autônomos. O processo de identidade é, entretanto, disputado como parte significativa da estratégia política das organizações e o resultado dessa disputa incide sobre sua política de comunicação.

Por isso, o foco específico desse trabalho é nas estratégias de apresentação de identidade em plataformas digitais por parte das organizações e não no processo de construção de identidades ao longo do tempo. Não busco verificar se as plataformas contribuem ou não para a formação de identidade coletiva - ou seja, se a identidade se forma apenas nas interações físicas ou se também resulta das interações digitais.

O que busco compreender é como as organizações lidam com um dilema que não é específico da Internet, mas que, com o advento das plataformas de mídias sociais, ganha ainda maior relevância. Mais especificamente, como e por quê cada organização da Rede EPL resolve de maneira diferente esse dilema, a 
partir da principal forma digital de contato com a opinião pública e com simpatizantes, que são suas páginas oficiais no Facebook. 


\section{A Rede EPL - Surgimento e caracterização}

Nos dias 17 e 18 de outubro de 2015 em São Paulo - SP, o grupo Estudantes Pela Liberdade realizou pela quarta vez sua Conferência Nacional ${ }^{22}$. Aberto a "curiosos e simpatizantes", o evento que aconteceu no moderno Centro de Convenções Rebouças se diferenciava de outros eventos de estudantes pelas boas condições de infraestrutura com que se realizava, por reunir representantes de uma larga gama de tendências do espectro político da direita e pela notável rede internacional que construíram, constatada pela presença de vários estrangeiros, vistos em grande número nas atividades da Conferência ${ }^{23}$.

Boas condições de infraestrutura é algo incomum nos eventos do movimento estudantil no Brasil, que são normalmente realizadas em ginásios, escolas e espaços públicos, sendo recorrente o alojamento dos participantes em acampamentos, com compartilhamento de barracas e de poucos banheiros em condições precárias.

Com uma lista de hotéis parceiros recomendados ${ }^{24}$ e sem qualquer discussão no sítio eletrônico e no próprio evento sobre a barreira que o alojamento exclusivo em hotel representava àqueles que não tinham condição de arcar financeiramente com os custos diretos de participação na Conferência, transpareceu uma naturalização dos estudantes sobre o perfil esperado dos participantes naquele espaço. $O$ entendimento de que a organização atrai e mobiliza um público mais abastado do que a média do corpo estudantil é expressado com grande objetividade em matéria publicada no site do Students For Liberty a respeito das origens de classe média de um Coordenador Local do EPL, líder e figura pública do MBL, Kim Kataguiri25:

\footnotetext{
22 Relato oficial da relização do evento disponível em: <http://epl.org.br/2015/10/24/como-a-foia-cnepl-2015/>. Acesso em 12 de fevereiro de 2016

${ }^{23}$ Foi realizada inclusive uma missão de lideranças internacionais do EPL para conhecer o trabalho da organização no Brasil, conforme registrado na matéria seguinte: $<$ http://studentsforliberty.org/blog/2016/01/05/supporters-trip-to-brazil/>Acesso em 12 de fevereiro de 2016.

24 Página do evento com sessão de comentários disponível em: $<$ http://www.eventick.com.br/cnepl2015>. Acesso em 12 de fevereiro de 2016.

25 Artigo disponível em <http://studentsforliberty.org/blog/2015/04/30/heres-how-one-sfl-localcoordinator-is-changing-brazil-for-the-better/>. Acesso em 12 de fevereiro de 2016.
} 
As perplexing as this middle-class sympathy to free enterprise may seem, it makes total sense in a country that's been ravaged by decades of government corruption from the left and military coups from the right. Today, Brazil is experiencing soaring inflation, stagnating GDP and a rising unemployment rate.

Ao afirmar que a simpatia da classe média aos ideais libertários é um eminente motivo de perplexidade, o grupo afirma tacitamente características que esperam e não esperam de seus participantes - algo que representa um elemento importante de sua identidade coletiva. Essa noção, entretanto, não significa que o SFL defenda publicamente que suas ideias não são benéficas aos mais pobres ou à classe média, muito pelo contrário. Entretanto, estranham que um estudante de classe média se reconheça em sua pauta.

Para o Congresso Nacional, não havia um código de vestimenta recomendado pela organização do evento, mas muitos participantes trajavam terno e gravata, enquanto outros usavam jeans, bermuda, ou calça com camisa social.

Figura 1 - Foto dos participantes da conferência

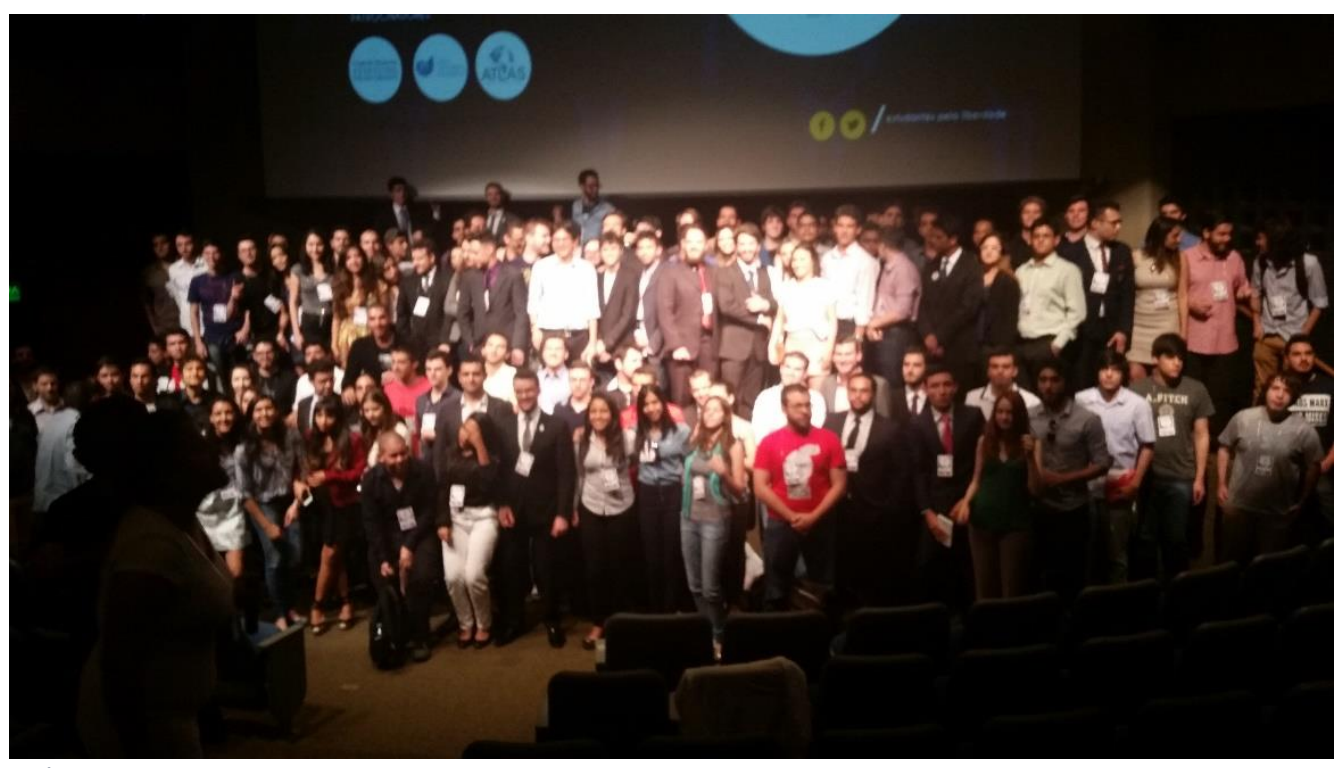

Créditos: Foto do autor

A grande quantidade de pessoas que se reunia para pegar um Uber em frente ao Centro de Convenções ao final do dia e nos intervalos de almoço foi uma boa oportunidade para conversar informalmente sobre as impressões dos participantes a respeito do evento. Um dos meus interlocutores chegou a demonstrar espontaneamente o incômodo com o traje excessivamente formal de alguns: "acho uma babaquice isso de usarem terno. Por culpa dessa galera, a 
gente fica com fama de ser careta e metido". Aproveitei a oportunidade para questioná-lo se não achava ruim o evento não se realizar em condições mais acessíveis financeiramente com alojamento coletivo, ao que ele me respondeu: “acampamento é ruim, desconfortável e bagunçado. Dormindo com mais conforto, o dia rende mais. Quem não recebeu apoio e não pode pagar hotel, fica na casa de um amigo ou, sei lá, arranja outro jeito".

Era evidente que a grande disponibilidade de recursos representava um ativo importante daquela rede. $\mathrm{E}$, com isso, me refiro não apenas à disponibilidade financeira pessoal de seus membros, mas aos recursos que a direção levantava para os eventos. Diversos palestrantes internacionais, como David Friedman (EUA), José Luis Cordeiro (Venezuela), David Schlessinger (Hong Kong/EUA), João Pereira Coutinho (Portugal), além de comediantes famosos e com elevados cachês no mercado, como Criss Paiva e Danilo Gentili, participaram da Conferência no Centro de Convenções Rebouças. Ao final do evento, houve ainda a distribuição de prêmios e um deles, no valor de $\mathrm{R} \$ 5.000,00$ (cinco mil reais), tinha o objetivo de fomentar um projeto que agregasse ao crescimento do EPL.

A capacidade de mobilização financeira do grupo também Ihes possibilita investir na ampliação da Rede, na formação de seus membros e na instalação de infraestrutura para a gestão e coordenação da organização, como explicarei detalhadamente mais adiante. Com mais de 700 coordenadores formados, 0 Estudantes Pela Liberdade tem presença em centenas de universidades nas cinco regiões do país, tudo isso em poucos anos de atuação.

Nas discussões de internet, na manifestação de opiniões nas páginas pessoais de seus membros e durante a Conferência, o EPL demonstrou-se capaz de articular e agregar uma larga gama de tendências do espectro da direita. Liberais, libertários, conservadores, minarquistas e anarcocapitalistas conversavam nos intervalos sobre os modelos de sociedade, mercado e Estado (ou de ausência deste) capaz de gerar os melhores impactos na sociedade. A capacidade de agregar diversas tendências dentro do espectro da direita, 
refletida inclusive nos palestrantes, demonstrou uma tendência fusionista ${ }^{26}$ do grupo. Com essa diversidade de participantes, o EPL conseguiu realizar, sem maiores percalços, dois painéis em sua 4a Conferência Nacional que são bastante controversos até mesmo para parte de seu público: um em defesa de fortalecer o armamento da população civil e outro negando as evidências de que ação antrópica seja fator decisivo para a existência do aquecimento global.

A conexão com a rede internacional se demonstra relevante para o EPL em três aspectos principais: no aumento dos repertórios disponíveis para ação política, no apoio político externo e no aporte financeiro. Nas entrevistas conduzidas, na análise de conteúdo e na experiência de campo, as três coisas puderam ser constatadas.

A importação de repertórios para a disputa política não é algo novo no Brasil. Como ressalta Bob (2012), a aliança do lobby pró-armas brasileiro com o lobby Americano, representado pela National Rifle Association ${ }^{27}$ - NRA, foi fundamental para reverter a vantagem inicial da posição pró-restrição do porte de armas no plebiscito brasileiro de 2005. A utilização desses repertórios também é bastante evidente no uso das redes sociais, onde diversas ideias e até mesmo peças de comunicação são utilizadas e adaptadas.

O apoio político externo, exercido a partir de arenas físicas ou virtuais fora do país, pode ter naturezas distintas. Uma delas é o reforço de suas bandeiras políticas ao mobilizar organismos internacionais e atores estrangeiros - como agências de rating, mídia, opinião pública, especialistas e outros. Um exemplo do que pode significar esse apoio foram as mobilizações pró-impeachment de

\footnotetext{
${ }^{26}$ O fusionismo é um termo oriundo do debate político dos Estados Unidos e representa a defesa da união entre conservadores, libertários de direita e outras correntes do campo em alianças de enfrentamento à esquerda. A origem desse termo é associada ao filósofo político Frank Meyer e ao comentarista William Buckley.

${ }^{27}$ A National Rifle Association é uma associação norte-americana sem fins lucrativos e isenta de taxas, criada para defender e fomentar os direitos da segunda emenda da Constuição dos Estados Unidos, relativa ao porte de Armas. No ano de 2014, a NRA possuía um patrimómio liquido superior a U\$123 milhões e arrecadou mais de U\$ 46 milhões.
} 
agosto de 2015, em que mais de $40 \%$ das postagens realizadas no Twitter se originaram de uma rede latino-americana de robôs anti-esquerda ${ }^{28}$.

De acordo com o entrevistado 5, fundador e dirigente do EPL, a principal importância do apoio externo para o EPL, entretanto, ainda seria o financiamento do grupo. Ele destaca que, além de outros países terem uma cultura maior de doação, a relação cambial faz essas doações serem muito favoráveis aos brasileiros. Com esses recursos, a rede consegue profissionalizar-se e realizar uma série de iniciativas onerosas financeiramente.

É certo que o EPL não é um movimento exclusivamente voltado para os espaços e pautas estudantis, mas, conforme informa um de seus dirigentes no Brasil, as regras do SFL colocam várias limitações à atuação política e, por isso, precisam de outras organizações para trabalhar as agendas que não podem executar como EPL. O Students For Liberty é uma filantropia regida pelo direito americano, vedada legalmente de se envolver em ações de caráter político ${ }^{29}$. Dessa maneira, o Estudantes Pela Liberdade encontra limitações para atuar em alguns campos e vocalizar determinados discursos. Também por isso, pode ser vantajoso criar outras iniciativas, com as quais mantém laços profundos, como é o caso do Mercado Popular, recém transformado em instituto, e o Movimento Brasil Livre, iniciativa pensada e fundada pelos membros do EPL - como será exposto mais adiante.

O conjunto dessas três organizações forma o que denomino de "Rede EPL". Agregada à estrutura dessas três organizações, há uma série de coletivos, como - Clube Farroupilha, a Aliança Pela Liberdade, Coletivo Nabuco e Clube Ajuricaba, além de outros, que funcionam como coordenações locais do EPL ou MBL ou mantém-se como coletivos satélites desses grupos.

O Mercado Popular é uma organização completamente fundada por membros do Estudantes Pela Liberdade. Além de ser um espaço no qual ex-membros do EPL podem continuar fazendo política e continuam conectados à rede, 0

28 Conforme dados do pesquisador do Labic/UFES, Fábio Malini $<$ https://www.facebook.com/photo.php?fbid=10153579287676151\&set=a.477225711150.29615 4.703916150\&type=3\&theater $>$. Acessado em 23 de Fevereiro de 2016.

${ }^{29}<$ http://apublica.org/2015/06/a-nova-roupa-da-direita/ $>$. Acesso em 22 de fevereiro de 2016. 
Mercado Popular atua como um think tank do EPL, cujo propósito - promover o liberalismo, em especial a noção de que a sua ideologia é mais adequada para gerar bem-estar aos mais pobres - é parcimoniosamente sintetizado no nome.

Ainda como demonstração de alinhamento político, o Mercado Popular fez algo incomum até mesmo entre organizações aliadas: a promoção do processo seletivo de coordenadores de outra organização - o EPL ${ }^{30}$. Também incomum foi a afirmação espontânea de dirigente do EPL, Entrevistado 5, de que está buscando levantar fundos para o Mercado Popular.

Organizações tendem a entrar em disputa por recursos estratégicos - como militantes, financiamento e espaço no debate público. Em alguns casos, essa disputa pode ser ainda mais notável entre organizações de um mesmo campo, pois disputam os mesmos potenciais doadores financeiros e público-alvo. Essa sólida interconexão - no compartilhamento de membros da direção, na promoção de processos seletivos e na disposição para captação de recursos de uma organização para outra - demonstra que as duas organizações são mais do que aliadas comuns, mas estruturas com funções diferentes dentro de um mesmo projeto.

No caso do Movimento Brasil Livre, o povoamento da direção com membros do EPL também é um elemento que reforça a conexão entre os dois grupos. Somase a isso a presença de dirigentes e figuras públicas do MBL na Conferência Nacional do EPL, alguns deles tanto na função de dirigentes do EPL, quanto do MBL.

A relação do EPL com o MBL, entretanto, é menos pública do que a relação com o Mercado Popular. Isso fica mais fácil de compreender à luz da linha política do $E P L$, que, por receber financiamento externo e ser uma organização transnacional com origem nos Estados Unidos, precisa ter mais cautela em sua exposição política. Conforme destaca um dirigente do EPL, Entrevistado 5:

O Movimento Brasil Livre, na verdade, em 2013 a gente criou ele, porque a gente não pode se envolver em atividades de

$30<$ https://www.facebook.com/130111460506319/posts/449535425230586> Acesso em 12 de janeiro de 2016. 
cunho político. A gente não pode defender, por exemplo, que a Dilma tem que ter um impeachment, ou que tal projeto de lei tem que ser aprovado ou recusado. Em 2013 estava havendo aquelas manifestações do Passe Livre, então a gente criou uma outra organização para participar disso. $\mathrm{Na}$ verdade, não desenvolveu muito impacto, a gente fez, criou panfleto, coisa do tipo e, no final do ano passado, a gente passou pra frente. Alguns ex-membros, algumas outras pessoas envolvidas assumiram a organização e, desde lá, tem crescido bastante, até aproveitando a impopularidade da Dilma nas manifestações, mas devido a esse cunho político deles, a gente ainda não tem nenhum projeto em comum, nenhuma relação além de alguns membros que fazem parte de ambas organizações.

Outros entrevistados definiram a relação das duas organizações como uma relação entre aliados, mas sempre destacando a existência de uma autonomia entre elas. Nesse sentido, a fundação do MBL por membros do EPL possui uma componente de intencionalidade ligada ao interesse de intervir diretamente na conjuntura sem as restrições inerentes à natureza do EPL. Não se trata de uma colateral ou de um movimento dirigido pelo EPL.

Considerando que o $\mathrm{MBL}$ foi fundado por membros do EPL, que há membros desta organização na direção desse movimento e que alguns entrevistados as reconhecem como duas organizações aliadas com concepções distintas, notase a existência de um alinhamento político pela proximidade ideológica e pelo compartilhamento de recursos, em que MBL e EPL se constroem conjuntamente compartilhando sinergias.

Essa descrição geral a respeito dos recursos compartilhados entre as três organizações permite entendê-las como uma rede política sólida, na qual uma organização forma jovens lideranças e disputa o movimento estudantil - EPL, outra trabalha como um think tank por meio de formulação política e de intervenções no debate público - Mercado Popular - e uma terceira vocacionada à ação política de massas, pela organização e direção de um grande contingente de pessoas em atos públicos.

Mercado Popular e Movimento Brasil Livre são duas organizações dirigidas por jovens oriundos da mesma organização política - Estudantes Pela Liberdade, razão pela qual esta última assume um papel central na coesa rede entre as 3 organizações. Em torno dessas 3 organizações circulam diversos outros 
pequenos coletivos e iniciativas individuais de promoção de ideias do campo político da direita.

Outras organizações que poderiam eventualmente ser incluídas na rede - como Instituto Millenium, Instituto Mises e Instituto de Estudos Empresariais - não possuem a mesma proporção de membros oriundos do EPL na direção, nem são dirigidas por jovens. A exceção que se poderia citar, pelo papel fundamental exercido na fundação do EPL, é o Instituto Ordem Livre. Entretanto, os fundadores do Instituto Ordem Livre se encontram no exterior, suas atividades foram cessadas e os direitos de uso da marca foram cedidos ao EPL.

A partir desses apontamentos iniciais, esse capítulo desenvolve-se com quatro seções de caráter descritivo. A primeira explica a origem do grupo Students For Liberty, seu histórico e suas conexões políticas. A segunda narra o processo de fundação do Estudantes Pela Liberdade no Brasil. A Terceira refere-se à criação do $\mathrm{MBL}$, suas origens e seus objetivos. A quarta e última seção explica o processo de criação do Mercado Popular e o trabalho em curso de construção de duas agremiações partidárias: o Partido Novo e a tendência Livres do Partido Social e Liberal.

\subsection{O Surgimento do Students For Liberty}

A formalização de uma organização ou movimento não representa o início de sua história. Antes disso, é necessário um processo em que pessoas, identidades, valores, discursos e recursos materiais se encontram na disposição e condição adequada para formar um novo ator coletivo e, posteriormente, registrá-la. Entender o começo de uma organização pode requerer ir além da identificação da solenidade em que ela é publicamente declarada, para analisar o processo anterior à sua fundação. Assim é possível compreender o contexto e as razões profundas de sua criação.

Fundado em 2008 em uma conferência realizada na Universidade de Columbia ${ }^{31}$, o Students For Liberty é resultado de um intenso processo de mobilização. Considerando as informações do sítio eletrônico do SFL e as

\footnotetext{
$31<$ http://studentsforliberty.org/about/>. Acesso em 16 de fevereiro de 2016.
} 
entrevistas de seus dirigentes disponíveis na internet, ao menos duas narrativas não-excludentes são encontradas.

Uma delas refere-se ao ativismo de Alexander McCobin, fundador e presidente do SFL. Se colocando no centro da narrativa, em uma construção que ressalta a sua agência, McCobin explica, em entrevista a Robert Begley disponível no sítio The Objective Standard ${ }^{32}$, como teve contato com o Libertarianismo e o Objetivismo, e o insulamento intelectual que passou a viver a partir de então.

Quando começou seus estudos na universidade Penn State em 2004, McCobin acreditava que estaria cercado por libertários, mas sentiu-se tão solitário e isolado, que relata ter pensado que isso era um sinal de que suas crenças deveriam estar erradas. Para reverter essa sensação de alheamento, McCobin decidiu organizar pessoas que tinham simpatia pelo libertarianismo. Em menos de dois anos, ele afirma, havia mais de 200 pessoas na lista de e-mails criada.

No verão de 2007, McCobin estava em Washington D.C, fazendo um estágio na Reason Foundation, quando decidiu organizar uma mesa redonda para discutir as melhores práticas de organização estudantil. Nessa atividade, ele e os demais participantes decidiram pela realização de um Seminário em fevereiro de 2008 na Universidade de Columbia, do qual resultou a fundação do Students For Liberty.

Em oito anos de funcionamento, o Grupo experimentou um crescimento vertiginoso. Somente no primeiro semestre de 2015, o grupo havia organizado 59 conferências, treinado 1427 líderes estudantis e alcançava a marca de 2847 grupos em todo o mundo (STUDENTS FOR LIBERTY, 2015a). Como descrito na seção About do sítio do SFL ${ }^{33}$ :

From those humble beginnings, the organization has grown each year to keep up with the rapidly growing demand and provide support to the student movement for liberty. The most recent International Students For Liberty Conference in 2015 featured over 1,700 attendees from all 6 inhabited continents.

$32<$ https://www.theobjectivestandard.com/issues/2014-winter/alexander-mccobin-studentsliberty $/>$. Acesso em 17 de fevereiro de 2016.

${ }^{33}<$ http://studentsforliberty.org/about/> Acesso em 16 de fevereiro de 2016. 
Ao explicar o crescimento vertiginoso de seu grupo, McCobin credita o sucesso a duas razões principais:

The first is that this is the libertarian generation. Millennials have grown up socially tolerant, fiscally responsible, and skeptical of the big-government (...) The second is SFL's leadership. From the beginning, we have invested heavily in identifying, training, and supporting the best people we can find, and that has been critical. 34

McCobin infelizmente não apresenta as razões pela qual a Millennials seria a geração libertária, socialmente tolerante, fiscalmente responsável e cética a respeito de governos grandes. Ao destacar a importância de se investir, treinar e apoiar as melhores pessoas que conseguem encontrar, o Presidente do Students For Liberty demonstra reconhecer o papel central de lideranças - ou empreendedores políticos - em movimentos sociais, o que também é relevante no campo da esquerda.

Para que seja possível o processo de desenvolvimento dessas lideranças, entretanto, é crucial que a organização tenha disponibilidade financeira ou a oferta de treinamento por organizações externas. O SFL possui em seu quadro ao menos 33 profissionais remunerados ${ }^{35}$ e, no período de maio de 2014 a abril de 2015 , gastou mais de US $\$ 3,643$ milhões, superando inclusive os US $\$ 3,184$ milhões arrecadados no mesmo período (STUDENTS FOR LIBERTY, 2015b).

Nesse sentido, a segunda narrativa sobre as origens da organização ajuda a compreender as fontes de recursos e projetos que garantem a existência do SFL. Em uma publicação recomendando seus membros a participarem do Institute for Humane Studies Koch Summer Fellow Program ${ }^{36}$, a organização informa:

The origins of Students For Liberty can be traced back to the summer of 2007 when several students in the Institute for Humane Studies Koch Summer Fellow Program got together on July 24th to hold a roundtable discussion about best practices for student organizations dedicated to liberty. As such, the KSFP is

$34<$ <ttps://www.theobjectivestandard.com/issues/2014-winter/alexander-mccobin-studentsliberty/>. Acesso em 17 de fevereiro de 2016.

${ }_{35}<$ http://studentsforliberty.org/leadership/>. Acesso em 16 de fevereiro de 2016.

${ }_{36}<$ http://studentsforliberty.org/blog/2011/01/28/ihs-koch-summer-fellow-program-deadline-toapply-january-31/>. Acesso em 16 de fevereiro de 2016. 
near and dear to SFL's heart, and we recommend the program to anyone even slightly interested in a career defending liberty.

Essa narrativa adiciona ao registro da história do surgimento do SFL a sua inserção em uma rede pré-existente; o conhecimento sobre os objetivos políticos mais amplos associados à sua fundação; e a compreensão sobre a existência de um conjunto de atores que visualizaram uma oportunidade política para a disputa da juventude e investiram nesse campo. Essa oportunidade política não se restringiu à fundação do SFL. No mesmo ano em que ela foi criada, surge, com apoio direto do Instituto Charles Koch ${ }^{37}$, o Young Americans for Liberty (YAL) uma organização cuja insígnia, estrutura e missão ${ }^{38}$ se confundem com a do SFL. Sobre a intencionalidade e o projeto prévio do conjunto de organizações que patrocinam a fundação do SFL, McCobin (STUDENTS FOR LIBERTY, 2009) enfatiza o fato do movimento já ter se tornado global em um ano de funcionamento e mostra até mesmo surpresa: "We had no idea what the magnitude of the Project we were embarking upon was when we held the first round table(...)". Essa surpresa e o tom de passividade com que se coloca dentro do projeto em que "embarcam" talvez revelem o protagonismo dessas organizações.

Ao analisar os principais doadores e parceiros do SFL, vemos, entre eles, várias instituições da rede financiada pelos Irmãos Koch, como a Atlas Network, Institute for Humane Studies, Cato Institute, Charles Koch Institute, dentre outras $^{39}$. Além disso, o SFL também recebe recursos por meio do Donors Trust ${ }^{40}$, um fundo largamente utilizado pelos irmãos $\mathrm{Koch}^{41}$ que possibilita o anonimato na doação.

\footnotetext{
$37<$ http://www.charleskochinstitute.org/liberty-work/partner-organizations/>. Acesso em 16 de fevereiro de 2016.

38 Conforme consta no sítio eletrônico da Organização: The mission of Young Americans for Liberty (YAL) is to identify, educate, train, and mobilize youth activists committed to winning on principle. Our goal is to cast the leaders of tomorrow and reclaim the policies, candidates, and direction of our government. <http://www.yaliberty.org/about/mission>. Acesso em 16 de fevereiro de 2016.

$39 \quad<h \mathrm{ttp}: / /$ www.sourcewatch.org/index.php/Koch Family Foundations $>\quad \mathrm{e}$ $<$ https://www.atlasnetwork.org/partners/global-directory/united-states $>$. Acesso em 17 de fevereiro de 2017

$40<$ http://www.donorstrust.org/what-we-offer/donor-advised-funds/>. Acesso em $17 \mathrm{de}$ fevereiro de 2016.

41 Para mais informações a respeito ver <http://www.desmogblog.com/who-donors-trust>, $<$ http://www.sourcewatch.org/index.php/DonorsTrust $>$
} 
Essas duas narrativas - a feita por McCobin e a construída com base nas organizações que sustentam esse projeto - estão conectadas pela existência de uma ideologia comum. A despeito dos elementos identitários apontados no início desse capítulo - o fato de serem, em geral, jovens de classe alta que compõem o grupo -, é possível observar com clareza a crença de que o livre mercado e a redução (ou ausência) dos governos é o melhor caminho para a sociedade. Há um largo número de entrevistas e textos, mostrando que tanto os irmãos Koch quanto os fundadores do SFL defendem o Libertarianismo e, talvez, não seja apropriado entender que os fundadores do SFL defendam o Libertarianismo porque os irmãos Koch assim o fazem.

Ao que tudo indica, mesmo antes de receberem apoio das fundações financiadas pelos irmãos Koch, os fundadores do SFL já debatiam o Libertarianismo. Compreender isso é importante para evitar a armadilha orwelliana de acreditar na existência de profunda manipulação e controle dos Irmãos Koch sobre as organizações que financiam, fenômeno que Tretjak (2013) registra como "Koch Brothers Fallacy".

O papel dos irmãos Koch, entretanto, e as implicações dos financiamentos que realizam, precisam ser compreendidos. Ao investir massivamente em formação de jovens e conectar oportunidades profissionais a isso, eles exercem profunda influência sobre esses jovens. Para as eleições americanas de 2016, conforme anunciado no dia 26 de janeiro de 2015 em um evento anual voltado a reunir doadores, a rede política articulada pelos irmãos Koch pretende investir US $\$ 889$ milhões, quantia que se equipara tanto ao que o Partido Democrata quanto ao que o Partido Republicano devem investir na campanha presidencial ${ }^{42}$.

Conforme informado em matéria escrita a partir de áudio de encontro realizado com grandes doadores em 2014, Kevin Gentry, funcionário da rede de instituições políticas dos Kochs, explica como funciona a complexa estrutura de influência montada, que começa na identificação de jovens mentes nos auditórios e salas das universidades, continua com a preparação desses

$<$ http://www.prwatch.org/news/2012/10/11819/meet-network-hiding-koch-money-donors-trustand-donors-capital-fund $>$. Acesso em 18 de fevereiro de 2016

$42<$ http://www.nytimes.com/2015/01/27/us/politics/kochs-plan-to-spend-900-million-on-2016campaign.html? $\mathrm{r}=0>$. Acesso em 18 de fevereiro de 2016. 
estudantes tendentes ao libertarianismo, e se concretiza com a colocação deles nos corredores do poder, no que eles chamam de talent pipeline ${ }^{43}$ :

"The [Koch] network is fully integrated, so it's not just work at the universities with the students, but it's also building state-based capabilities and election capabilities and integrating this talent pipeline, (...) So you can see how this is useful to each other over time. No one else has this infrastructure. We're very excited about doing it."

Relatório do Greenpeace ${ }^{44}$ a respeito da intervenção dos Kochs no ensino superior americano revela um acumulado de mais de US\$109 milhões de dólares no período de 2005 a 2014 e uma estreita conexão dessas doações com a contratação de professores indicados pelos doadores e a realização de estudos com resultados pré-determinados pelo grupo - como a negação da ação antrópica como fator essencial do aquecimento global.

A organização Polluters Watch listou cerca de 150 textos sobre como a influência dos irmãos Koch tem minado a liberdade acadêmica - desde a imposição de que as faculdades abram disciplinas como Free Market Environmentalism e a produção de artigos e pesquisas com resultados predeterminados. Entre esses resultados, encontram-se a comprovação de que Estados com menos impostos têm melhores desempenhos e a demonstração de que o Patient Protection and Affordable Care Act, chamado por seus opositores de Obamacare, gerará desemprego, redução na qualidade dos serviços e falência fiscal do Estado. De maneira bem parcimoniosa, a jornalista Kris Hundley elabora uma síntese robusta sobre como a rede política dos Koch submete as universidades ${ }^{45}$ :

Traditionally, university donors have little official input into choosing the person who fills a chair they've funded. The power of university faculty and officials to choose professors without outside interference is considered a hallmark of academic freedom. Under the agreement with the Charles G. Koch Charitable Foundation, however, faculty only retain the illusion of control. The contract specifies that an advisory committee

$43 \quad<$ http://www.theatlantic.com/education/archive/2015/10/spreading-the-free-marketgospel/413239/>. Acesso em 18 de fevereiro.

$44<$ http://www.greenpeace.org/usa/global-warming/climate-deniers/koch-pollution-on-campus/>. Acesso em 18 de fevereiro de 2016.

45 <http://www.tampabay.com/news/business/billionaires-role-in-hiring-decisions-at-florida-stateuniversity-raises/1168680>. Acesso em 18 de fevereiro de 2016. 
appointed by Koch decides which candidates should be considered. The foundation can also withdraw its funding if it's not happy with the faculty's choice or if the hires don't meet "objectives" set by Koch during annual evaluations

Theda Skocpol e Alexander Hertel-Fernandez (2016) vão além e mostram como o poder da coalisão dos irmãos Koch supera todas as demais coalisões que existiram no Partido Republicano, deslocando-o em direção à extrema direita e demonstram como resultado da atuação dessa coalisão sobre o governo amplia o distanciamento entre as políticas públicas formuladas e as preferências dos eleitores.

Como registrado no primeiro relatório anual da organização (STUDENTS FOR LIBERTY, 2009), Alexander McCobin trabalhou como Koch Associate para o Instituto Cato, antes de fundar o SFL e foi durante uma mesa no Institute for Humane Studies Koch Summer Fellow Programe que decidiu-se pelo evento de fundação do SFL. A partir de então, o SFL começou a funcionar em um escritório do Instituto Cato.

O SFL já surge dentro desse conjunto de organizações que possui valores, métodos, histórico e objetivos pré-definidos - o que, junto com a dependência financeira, gera alguns constrangimentos sobre as alternativas e decisões que a organização pode tomar. Além disso, a formação desses jovens é feita de maneira intensiva pelas organizações políticas da Rede dos Kochs.

Durante a Conferência Nacional do EPL, em 2015, ocorreram duas palestras sobre temas que pareciam fora da agenda local da organização, como a negação da ação antrópica como fator relevante do aquecimento Global (feita por David Friedman) e a defesa do armamento da população como um instrumento de defesa contra a tirania estatal (feita por Bene Barbosa). Nas duas, usou-se principalmente estudos de casos norte-americanos.

Mesmo que não estivessem na pauta local, esses dois temas fazem parte da agenda central dos financiadores e formuladores da rede. Essa é outra característica da estratégia de expansão do SFL ao redor do mundo, conforme declaram: a organização trabalha com um conjunto de ferramentas, pacotes ideológicos e banco de colaboradores para o desenvolvimento de sua rede - o 
que organiza o seu crescimento e garante a construção de maior homogeneidade.

Em sua identidade, a organização é fundamentalmente concebida para ser um espaço de formação em que jovens talentos propensos ao libertarianismo são treinados para serem líderes. A organização sintetiza a sua missão com o uso de três verbos (STUDENTS FOR LIBERTY, 2015b): educar jovens sobre a filosofia da liberdade, identificados aqueles que já sejam propensos aos ideários, ensinando-os os princípios da sociedade livre em contraste com a educação estatista tradicional; desenvolver habilidades de liderança entre aqueles que apoiam a "liberdade"; e empoderar seus membros e ex-membros, provendo-os com recursos, rede, infraestrutura e todo tipo de apoio que precisarem para fazer o mundo mais livre.

Aberto a adesão de grupos que se identifiquem com o ideal libertário, o SFL apesar de se apresentar como uma rede que não é top down e que não se organiza por capítulos, possui uma estrutura hierárquica tradicional, com direções locais, regionais, nacionais e internacional ${ }^{46}$, apoiada por conselhos executivos e de orientação. Os grupos que se incorporam à organização passam a ter acesso a recursos financeiros, palestrantes, livros, oportunidades de emprego, cursos com bolsas de estudos, manuais, retiros, eventos de formação, entre diversos outros tipos de recursos. Essa infraestrutura montada representa um grande incentivo para a incorporação e criação de células na organização.

\subsection{Estudantes pela Liberdade no Brasil}

O grupo Estudantes Pela Liberdade é a seção brasileira do Students For Liberty, apesar de, na aba "Quem somos" do sítio eletrônico, não fazerem nenhuma menção a isso, nem usarem a palavra internacional ou qualquer um de seus sinônimos. Há um certo esforço do grupo em não serem identificados como uma organização transnacional, mas algumas coisas - como a identidade visual, o discurso, o conteúdo e a estrutura do sítio eletrônico montado sob a plataforma

\footnotetext{
${ }^{46}<$ http://studentsforliberty.org/about/>. Acesso em 21de Fevereiro de 2016.
} 
do sítio internacional - levam o usuário que conhece, mesmo que vagamente, o SFL a fazer a conexão entre EPL e SFL.

$\mathrm{Na}$ seção lideranças ${ }^{47}$ do sítio eletrônico do EPL, o texto de apresentação começa com a afirmação "Somos um movimento legitimamente nacional", enquanto, logo abaixo da barra de navegação, a indicação "Students for liberty sites" em conjunto com a logomarca do SFL - cujo link original foi substituído pelo endereço da página principal do EPL - sugerem que o movimento seja transnacional.

Durante as entrevistas, os membros do EPL foram bastante cautelosos sobre suas conexões internacionais. Na entrevista, ao ser perguntado se, na relação com parceiros internacionais, havia uma formulação conjunta de política ou um espaço para trocas de ideias, o Entrevistado 5 afirma que não e que se trata apenas de parceria para captação de recurso financeiro. O Entrevistado 3 caracteriza tais relações como indiretas e informais, inclusive no que se refere ao apoio financeiro. Já o Entrevistado 4 afirma que eles buscam principalmente aprender com essas organizações sobre o que eles fizeram, como fazem e o que pode ser copiado. Além disso, prossegue o Entrevistado 4, eles buscam apoio, de natureza ampla, como treinamentos e recursos financeiros.

No sítio eletrônico do EPL, há diversas entrevistas, recursos digitais e textos traduzidos do sítio do SFL, replicados como textos do próprio EPL. Isso, entretanto, pouco diz sobre o grau de autonomia do EPL em relação ao SFL. Há de fato, muito conteúdo sendo produzido localmente e, aparentemente, nenhum conflito relevante entre SFL e EPL. Do outro lado, entretanto, a percepção parece ser inversa, com o SFL reivindicando a atuação do EPL e, em alguns momentos até mesmo do MBL, como sua própria atuação.

O Relatório Trimestral do SFL (2015a) tem em toda a extensão de sua capa a foto de uma manifestação de rua no Brasil. Duas das três chamadas principais são para matérias sobre o trabalho da organização no Brasil. Com frases como "after growing at a staggering rate of $100 \%$ per semester, Brazil now is home to half of all SFL's volunteers" (2015a, p. 7), "In October, our team in Brazil

\footnotetext{
$47<$ http://epl.org.br/liderancas/>. Acesso em 21 de Fevereiro de 2016.
} 
Estudantes Pela Liberdade held their $4^{\text {th }}$ annual national conference in Sao Paulo" (2015a, p. 5) e "SFL's work in Brazil shows how successful our strategy of social change can become, as EPL has already incubated leading journalists, politicians, entrepreneurs, academics, and civil society leaders" (2015a, p. 14), a SFL reivindica, sem hesitação, o trabalho realizado no Brasil como seu.

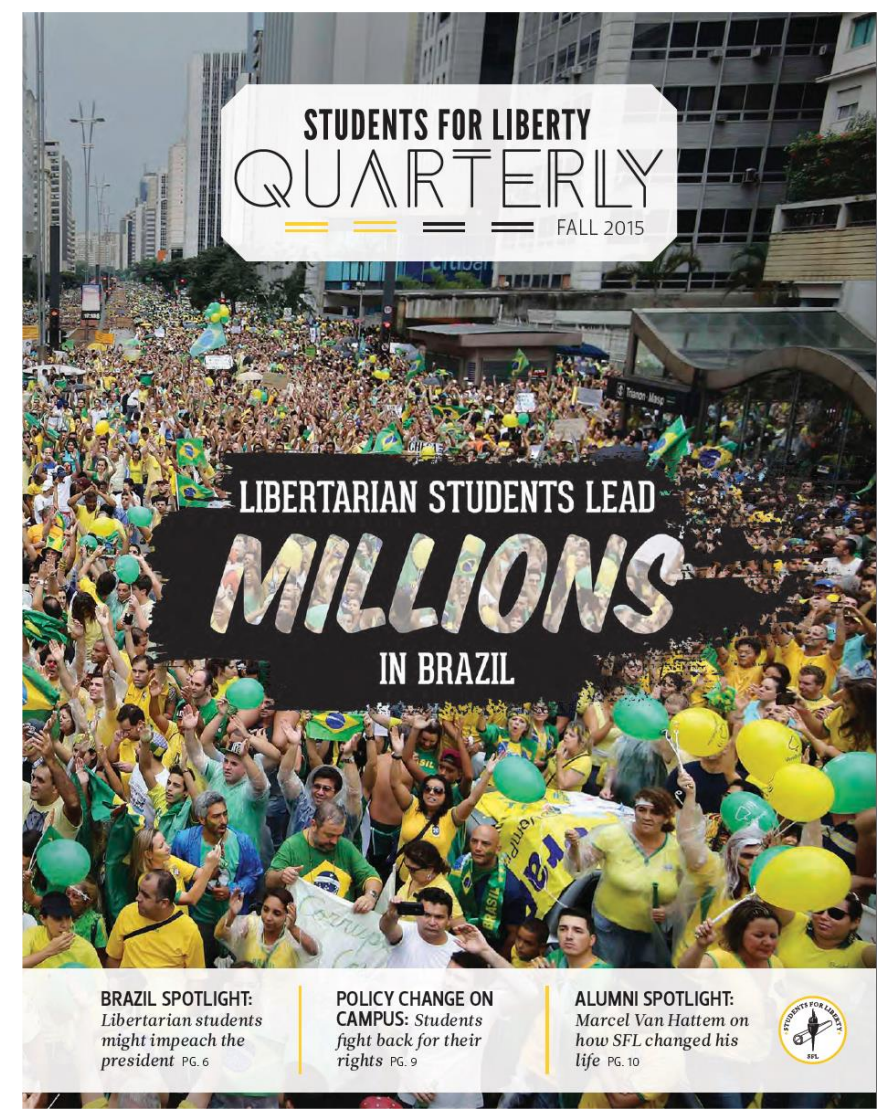

Figura 2- Capa do relatório trimestral EPL Outono de 2015

Considerando apenas a relação financeira entre as duas organizações, cabe ressaltar que, dos 33 profissionais remunerados pelo SFL, três são brasileiros dedicados à construção EPL - Juliano Torres, Bernardo Vidigal e Ivanildo Terceiro $^{48}$. Isso significa que os principais dirigentes do EPL são também funcionários do SFL. Sobre os demais dados financeiros, como as fontes de recurso da organização e os gastos realizados, não há informações disponíveis. As duas únicas prestações disponíveis nos sítios eletrônicos - de 2012 e 2013 ${ }^{49}$ - não informam sobre o pagamento de profissionais, sobre o aluguel de salões para eventos, sobre o pagamento de palestrantes ou sobre a doação desses

\footnotetext{
$48<$ http://epl.org.br/liderancas/> e < http://studentsforliberty.org/leadership/>. Acesso em $22 \mathrm{de}$ fevereiro de 2016

49 <http://epl.org.br/prestacao-de-contas/>. Acesso em 22 de fevereiro de 2016.
} 
itens por terceiros. Na declaração mais recente disponível online, constava como receitas o valor de $R \$ 31.466,75$ (trinta e um mil, quatrocentos e sessenta e seis reais e setenta e cinco centavos) - totalmente oriundo de doações de pessoas físicas.

Entre as atividades políticas onerosas financeiramente realizadas pelo EPL, encontram-se as conferências nacionais, regionais e estaduais, os seminários, os cursos, os programas de disseminação do libertarianismo nas escolas, o Libertrip e a distribuição de livros, entre outros. Não há dados sobre o apoio fornecido à participação nos grandes eventos nacionais - como a Conferência Nacional e o Encontro de líderes -, mas, para eventos de menor escala, como o Encontro Regional do Centro-Oeste, é possível encontrar anúncio no Facebook ${ }^{50}$ de apoio financeiro para quatro representantes de cada estado da região, cobrindo transporte aéreo, hospedagem e alimentação para os participantes. Exclusivamente para o Encontro Regional Sudeste de 2015, o coordenador executivo, Lucas Borges, relatou a disponibilidade de recursos para custear, o evento e participação de 35 a 40 coordenadores, além da oferta de reembolso de $R \$ 200,00$ (duzentos reais) para cobrir a participação de coordenadores de outras regiões pelas Atlas Network e Friedrich Naumann Stiftung ${ }^{51}$. Trata-se de um significativo apoio financeiro que possivelmente é realizado em todas as conferências do grupo.

Considerando-se a origem da remuneração dos dirigentes do EPL, o enorme contingente de estudantes selecionados para cursos e eventos no exterior e 0 volume de recursos aplicado nas atividades cotidianas da organização, nota-se que o investimento das organizações estrangeiras é decisivo para 0 funcionamento do EPL.

No que se refere à plataforma política, os conteúdos compartilhados tanto pelo SFL, quanto pelo EPL se assemelham. Entre as pautas tradicionalmente associadas à direita encontram-se o fim do salário mínimo e dos direitos trabalhistas, redução do Estado, privatização da educação e defesa do porte de

$50<$ https://www.facebook.com/wender.kenny/posts/957944577587816/>. Acesso em 22 de fevereiro de 2016.

$51<$ <http://epl.org.br/2015/04/26/como-foi-o-encontro-regional-de-liderancas-do-sudeste/>. Acesso em 22 de fevereiro de 2016. 
arma por civis. Há também outras pautas tradicionalmente associadas à esquerda, que também fazem parte do universo libertário, como a legalização das drogas e a união civil de casais do mesmo sexo.

Para fortalecer o debate e a coexistência de tendências políticas diferentes dentro de seu espectro, o EPL criou uma categoria de textos chamada "os dois lados da moeda"52. Nele, temas não-consensuais como a proibição do Fois Gras pelo Estado e a abertura das fronteiras à imigração são debatidos, ressaltando as diferenças de cada perspectiva. Essa abertura, entretanto, é relativa e encontra algumas barreiras. Há temas que são evitados e pautas que são tratadas com maior discrição, como o aborto. Em 09 de fevereiro de 2016, por exemplo, foi feita uma postagem sobre este tema com uma perspectiva conservadora frontalmente incompatível com o liberalismo e o libertarianismo, que já não estava mais disponível em 22 de fevereiro de 2016, e só pode ser acessada em webcache ${ }^{53}$

Figura 3 - Instantâneo de tela de web cache do sítio eletrônico do EPL

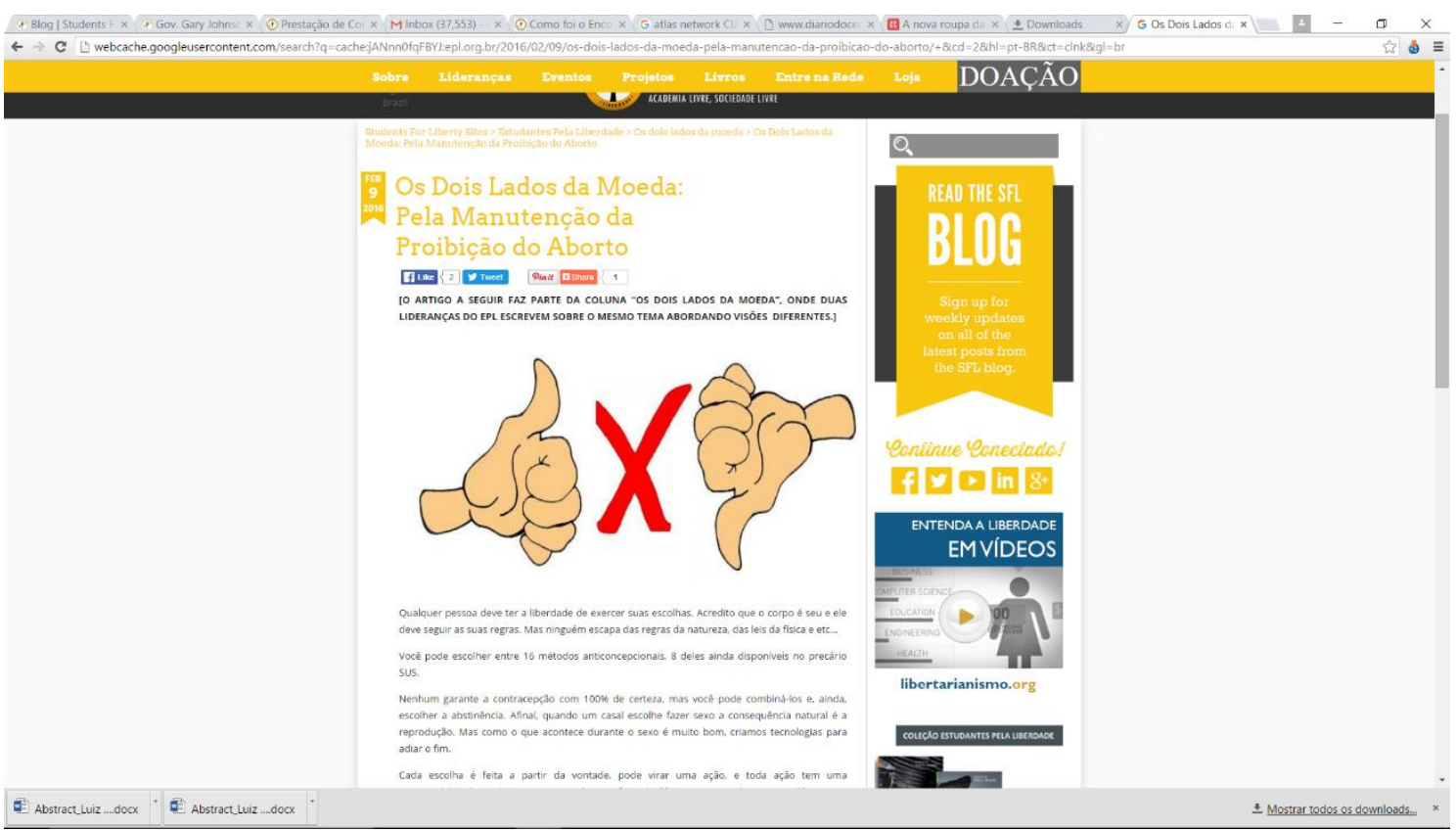

$52<$ http://epl.org.br/category/os-dois-lados-da-moeda/>. Acesso em 22 de fevereiro de 2016. 53

$<$ http://webcache.googleusercontent.com/search?q=cache:jANnn0faFBYJ:epl.org.br/2016/02/0 9/os-dois-lados-da-moeda-pela-manutencao-da-proibicao-do-aborto/+\&cd=2\&hl=ptBR\&ct=clnk\&gl=br>. Acesso em 22 de fevereiro de 2016. 
Esse embargo à discussão do aborto é outro elemento que pode estar conectado à dificuldade que o grupo encontra para se reconhecer como uma organização transnacional. Assim como reconhecer seu caráter transnacional traz dificuldades à expansão do grupo, tomar uma posição sobre um tema polêmico como a legalização do aborto representaria um fortalecimento da identidade do grupo, mas representaria uma limitação em sua capacidade de expansão e, principalmente, atrapalharia a estratégia fusionista por afastar conservadores de sua esfera de influência.

A história de fundação do EPL encontra algumas versões que demonstram com clareza esse incômodo em debater temas polêmicos e em se colocar como uma organização transnacional. No Wikipedia ${ }^{54}$, o termo "Estudantes Pela Liberdade", que registra a tradução do termo SFL, possui um alerta da comunidade wiki de que a neutralidade do artigo foi questionada. Nesse artigo, há uma tentativa bastante confusa na seção Brasil de se fazer uma distinção entre EPL e SFL:

Apesar do EPL [aqui referindo-se ao SFL] ter iniciado sua
expansão para a América Latina da mesma forma que está
fazendo na África e Ásia, não foi estabelecido uma seccional da
organização no Brasil, já que desde 2010 existia no país uma
organização estudantil baseada na ideia do grupo americano. O
Estudantes Pela Liberdade Brasil, é uma organização sem fins
lucrativos que tem como objetivo promover, a partir da Academia,
uma ordem social harmônica, justa e livre, ancorada no respeito
às liberdades individuais, à propriedade privada e à vida humana,
sendo somente uma organização somente parceira do EPL
[também referindo-se ao SFL].'

Na página de discussão sobre a edição do termo Estudantes Pelo Liberdade ${ }^{55}$, encontra-se alguns registros desse debate. Um usuário alerta que o artigo está sendo escrito por pessoas da própria ONG, utilizando informações referenciadas com páginas sob domínio da própria ONG e solicitando que sejam utilizadas fontes independentes, ao que Carlos André Góes, um dos fundadores do EPL responde: "Você está enganado. Esse artigo é sobre o Students for Liberty -

$54<$ https://pt.wikipedia.org/wiki/Estudantes Pela Liberdade>. Acesso em 22 de fevereiro de 2016.

$55<$ https://pt.wikipedia.org/wiki/Discuss\%C3\%A3o:Estudantes Pela Liberdade>. Acesso em 22 de fevereiro de 2016. 
uma organização americana. Imagino que nenhum dos editores seja membro da ONG".

De fato, o reconhecimento do EPL como uma organização norte-americana poderia gerar dificuldades políticas ao grupo, que teria menor facilidade em recrutar membros e poderia encontrar resistências de setores mais nacionalistas. Há diversas matérias jornalísticas sobre as conexões internacionais do EPL - que também se aplicam ao MBL - com a rede de think tanks e fundações americanas financiada pelos Irmãos Koch, como as realizadas pela Agência Pública ${ }^{56}$, pela Carta Capital $^{57}$ e pela Revista Fórum ${ }^{58}$, que geraram reações acaloradas dos leitores das reportagens. As Chapas de DCE, o trabalho do Liberdade nas Escolas e todos os demais eventos do EPL poderiam ser prejudicados pela associação com o SFL.

De qualquer forma, como ressalta Ricardo Frizera, coordenador regional do EPL, em seu perfil do Facebook: "esse ano nos tornamos (Brasil) um dos maiores chapters da maior rede de formação de líderes estudantis do mundo". A narrativa de criação do EPL dada por seus fundadores, entretanto, costuma ignorar essa conexão.

A primeira ausência notável no sítio eletrônico do EPL é a descrição da história de sua fundação. Sem um relato oficial, a principal base para essa narrativa foi dada nas entrevistas e em um texto de referência sobre a organização recente do movimento liberal no Brasil, escrito por Felipe Celeti ${ }^{59}$.

Conforme indicado em ambas narrativas, o EPL surge como resultado de um seminário realizado em Petrópolis-RJ no ano de 2012, que reuniu estudantes libertários de todo o país. O Entrevistado 5 narra, na entrevista, que o objetivo do seminário era apenas reunir as pessoas para compartilharem suas experiências e a fundação do EPL foi um resultado não esperado a partir da

\footnotetext{
${ }^{56}<$ http://apublica.org/2015/06/a-nova-roupa-da-direita/>. Acesso em 22 de fevereiro de 2016. $57<$ http://www.cartacapital.com.br/blogs/outras-palavras/quem-esta-por-tras-do-protesto-no-dia15-3213.html >. Acesso em 22 de fevereiro de 2016.

$58<$ <http://www.revistaforum.com.br/rodrigovianna/outras-palavras/os-meninos-golpe-dia-15quem-banca-essa-turma/ $>$. Acesso em 22 de fevereiro de 2016.

$59<$ <ttp://mercadopopular.org/2014/02/a-historia-do-movimento-libertario-brasileiro/>. Acesso em 22 de fevereiro de 2016.
} 
sugestão de um dos participantes - Anthony Ling - que já conhecia o SFL. Antes de 2012, ele indica, o grau de organização do movimento 'liberal' no Brasil era muito baixo e mais intenso nas arenas virtuais - Orkut e, depois, Facebook. $\mathrm{O}$ Entrevistado 2, entretanto, afirma que a fundação do EPL em 2012 foi um mero ato de formalização jurídica, que a organização já existia de fato desde 2010. Não obstante ato de fundação em 2012 ser meramente um ato de formalização jurídica, o grupo desenvolve uma narrativa que relembra a fundação do SFL nos Estados Unidos: tal como lá, aqui a fundação se deu num seminário acadêmico, cuja intencionalidade era apenas discutir ideias libertárias, e, em ambos os países, o seminário foi financiado pela mesma rede de organizações.

Quando indagado sobre quem organizou o seminário, a resposta do Entrevistado 5 foi simples: "Atlas Network" - a principal parceira do SFL e também financiadora do Instituto Ordem Livre - também indicada por Felipe Celeti como a organizadora do mesmo seminário. O papel do Instituto Ordem Livre, ainda, merece destaque. Financiado pela Atlas, desde 2009 o Instituto Ordem Livre realizava no Brasil o Liberdade na Estrada ${ }^{60}$ :

(...)evento anual iniciado em 2009 leva intelectuais liberais a universidades brasileiras, promovendo palestras e debates que abortam tópicos relevantes para o debate público nacional. Nas cinco primeiras edições do projeto, o Liberdade na Estrada visitou quase 50 universidades, em mais de 30 cidades brasileiras, atraindo para seus eventos milhares de estudantes, além de cobertura na imprensa local e nacional.

Nos registros de Celeti e também nas menções feitas pelos Entrevistados 1, 3, 5 e 7, o Orkut foi indicado o primeiro espaço virtual responsável por conectar indivíduos e coletivos liberais ou libertários Brasil afora, sendo uma ferramenta facilitadora da interação e da interconexão entre grupos e militantes dispersos. A partir dele foi muito mais simples mobilizar as pessoas para os encontros presenciais que ocorreram depois, inclusive o seminário de fundação em Petrópolis.

Por meio desse evento e das plataformas virtuais, formou-se uma base de dados de lideranças estudantis e simpatizantes que serviu de base para os trabalhos

$60<$ http://ordemlivre.org/Ine>. Acesso em 22 de fevereiro de 2016. 
posteriores de fundação do EPL. Além disso, como relatado em entrevistas, alguns dos participantes já haviam participado de atividades da SFL nos Estados Unidos, sugerindo a fundação da organização no Brasil. Em uma matéria no sítio do EPL ${ }^{61}$, Fábio Ostermann revela:

Em meados de 2008 eu havia descoberto o Students For Liberty quando fui aos EUA participar da Cato University e conheci 0 Alexander McCobin (fundador e Presidente do SFL). Voltei com a ideia de tentar replicar a experiência (ainda incipiente) deles por lá. [...] resolvemos no final de 2009 dividir o CERC em dois projetos: um com viés mais acadêmico e com vistas a debater possibilidades políticas públicas e outro com a proposta de ter um foco maior na promoção das ideias liberais a partir das universidades (o EPL).

Nessa narrativa, é possível identificar a existência de diversos atores espalhados pelo Brasil, que se conheciam de outros espaços, principalmente por meio da internet, e que já conheciam o SFL. O Papel da Atlas Network associada ao Instituto Ordem Livre foi o de identificar e de conectar fisicamente esses atores entre si e ao projeto do SFL, dentro da rede de instituições e think tanks libertários.

\subsection{Movimento Brasil Livre}

A primeira aparição digital do Movimento Brasil Livre data de 17 de junho de 2013, quando a página do Movimento foi criada no Facebook. Conforme informa o Entrevistado 3, a ideia para criação do movimento partiu de Juliano Torres, durante as manifestações de junho de 2013, que enxergou naquele momento uma oportunidade para criar um movimento pautado pelas ideias libertárias no Brasil. No início, afirmou o Entrevistado 5, fizeram mobilização, distribuíram panfletos, mas o trabalho não teve muito impacto. A responsabilidade pela iniciativa foi então passada a alguns ex-membros do EPL e pessoas de fora da organização que se envolveram no processo de construção do MBL. Como narra Fábio Ostermann em matéria do EPL a respeito do movimento que fundou com Felipe Melo França e Juliano Torres ${ }^{62}$ :

$61<$ http://epl.org.br/2015/12/09/epl-entrevista-fabio-ostermann/>. Acesso em 22 de fevereiro de 2016.

$62<$ http://epl.org.br/2015/12/09/epl-entrevista-fabio-ostermann/>. Acesso em 23 de fevereiro de 2016. 
O movimento surgiu como uma tentativa de ajudar a dar uma direção mais prática aos fugazes movimentos de junho de 2013, mas acabou causando impacto mesmo a partir de novembro de 2014, quando convidei Renan Santos e seu irmão, Alexandre, para ajudarem a tocar o movimento a partir de São Paulo (à época eu ainda vivia em Porto Alegre). Eles logo se uniram a um guri bem novo de origem nipônica e, novamente, o resto é história!

Desde essa mudança de direção, o Movimento tem aproveitado a baixa popularidade da Presidenta Dilma Rousseff para crescer. Talvez seja esse segundo momento - em que há uma reformulação - o referencial de Kim Kataguiri para a fundação do Movimento Brasil Livre, já que ele afirma que o início do Movimento teria se dado apenas em novembro de $2014^{63}$, não em junho de 2013. O objetivo do Movimento, conforme afirmou em entrevista o Entrevistado 6, é o impeachment da Presidenta Dilma Rousseff e a derrubada de seu partido. Para ele, a corrupção do PT é diferente da corrupção dos demais partidos, pois não é um fim em si próprio, uma forma de enriquecimento individual, mas um meio de implementar um projeto de sociedade, que ele rechaça.

Organizado em células, Kim informa na entrevista em outubro de 2015 que o MBL tem mais de 180 agremiações, número que crescia a passos largos. Conforme indica mapa interativo de $\mathrm{MBL}^{64}$, o Movimento está em ao menos 126 cidade do país.

O discurso de rejeição aos partidos políticos que marcou o MBL até meados de 2015 se alterou. Com a proximidade das eleições municipais, o MBL retirou a palavra "apartidário" de sua descrição e passou a publicamente declarar que vai lançar candidatos em diversos partidos políticos. A noção de apartidarismo já era difícil de sustentar, visto que um de seus líderes, Marcel van Hattem, é deputado estadual pelo Partido Progressista (PP) no Rio Grande do Sul; que dois de seus dirigentes, os irmãos Alexandre e Renan Santos, coordenaram a campanha a

${ }^{63}$ Conforme matéria jornalística disponível em <http://ultimosegundo.ig.com.br/politica/2015-0312/roqueiro-e-ativista-na-web-lider-anti-dilma-defende-privatizar-saude-e-educacao.html>. Acesso em 23 de fevereiro de 2016. $64<$ https://mbl.org.br/onde-estamos $>$. Acesso em 23 de fevereiro de 2016. 
deputado estadual em São Paulo ${ }^{65}$ de Paulo Batista; e que este, filiado ao PRP, era uma liderança do MBL até janeiro de $2015^{66}$.

Entretanto, considerando o longo histórico de críticas amplas a partidos, inclusive da direita, parece pouco provável que o MBL seja dirigido por algum partido. Durante palestra sobre a fundação do Partido Novo na Conferência Nacional do EPL, Marcel Van Hattem demonstrou entusiasmo com o Partido que estava ajudando a fundar, mas defendeu que fossem construídas também candidaturas em outras legendas, desde que houvesse alinhamento com as pautas libertárias.

Conforme demonstra discussão na plataforma Reddit ${ }^{67}$ - utilizada pelo Movimento para debates virtuais - o grupo cogitou três possibilidades como estratégia eleitoral: filiar-se a um partido existente - o Novo, o Democratas ou o PSDB; filiar-se a vários partidos dentro do espectro da direita; ou fundar um partido próprio. A posição prevalecente para o curto prazo foi pela filiação a vários partidos, uma vez que o movimento já anunciou que apresentará mais de cem candidaturas em diversas legendas ${ }^{68}$.

O histórico do MBL é de um movimento em rápida transformação. Apesar de sua origem entre os quadros do EPL, o MBL assumiu a missão de massificar o libertarianismo e, para isso, precisou fazer um discurso com uma estética mais popular e não se manifestar sobre diversos assuntos que ferem o senso comum para poder se aproximar das massas, fortalecer o impeachment de Dilma Rousseff e ter viabilidade eleitoral. Em entrevista ao jornal EL País ${ }^{69}$, ao ser indagado sobre diversas questões polêmicas como aborto, criminalização da homofobia, casamento gay e legalização das drogas, o grupo evita se manifestar

\footnotetext{
$65<$ http://revistapiaui.estadao.com.br/materia/tea-party-a-brasileira/ $>$. Acesso em 23 de fevereiro de 2016.

$66<$ https://www.facebook.com/paulobatistaoficial/videos/1611533545732751/>. Acesso em 23 de fevereiro de 2016.

${ }^{67}<$ https://www.reddit.com/r/territoriolivre/comments/3m0xe7/defini\%C3\%A7\%C3\%A3o do parti do em que os militantes do $\mathrm{mbl} />$. Acesso em 23 de fevereiro de 2016.

$68<$ http://oglobo.globo.com/brasil/movimentos-pro-impeachment-mudam-discurso-vao-asurnas-18491850>

$<$ http://epocanegocios.globo.com/Informacao/Acao/noticia/2015/09/movimento-brasil-livre-serende-ao-sistema-e-lanca-nomes.html>. Acesso em 23 de fevereiro de 2016.

$69<$ http://brasil.elpais.com/brasil/2014/12/12/politica/1418403638 389650.html>. Acesso em 23 de fevereiro de 2016.
} 
e responde: "não está na pauta do grupo", apesar de eventualmente deixar escapar algo como "a maior parte do grupo é contra" ou "os líderes de São Paulo são a favor".

Dentro da comunidade da direita, o posicionamento político do $\mathrm{MBL}$ - com grande visibilidade pública - é alvo de críticas de quem se posiciona à sua direita e à sua esquerda. De um lado, por exemplo, o movimento conservador cristão Libertar $^{70}$ condenou duramente o MBL por lançar candidaturas políticas e disputar a política institucional. De outro, o Mercado Popular divulgou artigos contra a estratégia do MBL de lutar pela derrubada da Presidenta Dilma Rousseff. Ambos os textos do Mercado Popular, de autoria de Felipe Trentin ${ }^{71} \mathrm{e}$ Roberto Xicó, ${ }^{72}$ defendem a estabilidade institucional e questionam a estratégia do MBL pelo impeachment.

MBL e EPL não se associam publicamente e não compartilham projetos de maneira explícita, conforme declarado nas entrevistas. Certamente, essa associação pública não ajudaria o trabalho de nenhuma das duas organizações dado o foco delas em públicos diferentes, mas podem haver outras razões.

Nos Estados Unidos, entretanto, o SFL tem largamente se associado ao MBL, destacando como o trabalho da organização norte-americana no Brasil foi fundamental para o sucesso do Movimento no Brasil - e das manifestações em geral. Com um texto intitulado Libertarian Students lead millions in Brazil, o SFL afirma (2015a, p. 8):

Another and more widely known EPL alum is Kim Kataguiri, a 19year-old libertarian who is one of the leaders of the Free Brazil Movement calling for the impeachment of the president. After the ruling Labour Party and President Dilma Roussef became embroiled in multiple corruption scandals, Kim took to the streets in protest. Over the past year, the Free Brazil Movement has grown dramatically to include protests by millions of individuals, massive mainstream media attention, and strong political support for the impeachment of the president. For all his work this past year, Kim was recently named one of Time Magazine's 30 Most

$70<$ http://www.libertar.in/2016/01/vendidos-mbl-muda-discurso-e-lancara.html>. Acesso em 23 de fevereiro de 2016.

$71<$ http://mercadopopular.org/2015/03/felipe-trentin-por-que-nao-vou-pra-rua-no-dia-15/>. Acesso em 23 de fevereiro de 2016.

$72<$ http://mercadopopular.org/2015/05/o-impeachment-nao-e-uma-pauta-liberal/>. Acesso em 23 de fevereiro de 2016. 
Influential Teens of 2015. EPL leaders are having an impact, and our training is being recognized because so many of our students are being accepted into libertarian seminars across the Americas, another great achievement. The challenges of the liberty movement in Brazil are enormous, but with these results, EPL is having an impact on the Brazilian political landscape.

Em diversas reportagens brasileiras, o MBL é indicado como recipiente de dinheiro dos Irmãos Koch, informação que rebatem. Em abril de 2015, numa matéria do SFL, Kim reclama da falta de apoio financeiro:

Yet, besides receiving free training and a few books from SFL, Free Brazil is a low-budget operation of its own. "Unfortunately, we don't have any big sponsors," Kataguiri told The Guardian. "The government and some sectors of the press say that we are financed by rich people. We would have no problem in being financed by rich people."

Com fortes campanhas de arrecadação via sítios de financiamento e por meio da venda de brindes, torna-se plausível a versão do MBL de que não teria, ao menos até aquele momento, recebido recursos. A disposição demonstrada pelo Entrevistado 5, entretanto, foi de que o SFL ajudaria o MBL a arrecadar recursos com seus doadores internacionais ${ }^{73}$ :

O Kim, inclusive, vai participar agora de um torneio de pôquer filantrópico que o Students For Liberty organiza em Nova York para arrecadar recursos. Ele vai ser um palestrante. $E$ também na conferência internacional em fevereiro, ele vai ser palestrante.

O Movimento Brasil Livre já aparece como parceiro da Atlas Network no sítio eletrônico desta organização ${ }^{74}$, sem especificação sobre a quantidade de recursos e a forma de parceria. Mas, como afirma o Entrevistado 6, o Movimento não teria problema em receber doações internacionais, ainda que talvez tenha dificuldade em reconhece-las. Além disso, o MBL conseguiu se expandir sem, aparentemente, depender de grandes financiadores e segue seu trabalho, de sua sede compartilhada na avenida paulista, buscando mais recursos sem uma grande infraestrutura para ser custeada. É importante registrar, entretanto, que

\footnotetext{
${ }^{73}<$ http://apublica.org/2015/06/a-nova-roupa-da-direita/>. Acesso em 22 de fevereiro de 2016.

$74<$ https://www.atlasnetwork.org/partners/global-directory/movimento-brasil-livre>. Acesso em 21 de fevereiro de 2016.
} 
o núcleo dirigente do MBL oriundo do EPL também é formado em cursos e seminários pelas instituições filantrópicas da rede dos irmãos Koch.

\subsection{Mercado Popular e partidos}

Com domínio virtual registrado em março de 2013, alguns meses antes dos protestos de junho de 2013, o Mercado Popular funciona basicamente como um think tank virtual, em que seus colaboradores, espalhados por muitas cidades, inclusive de fora do país, postam artigos de opinião sobre os mais diversos assuntos. O mais antigo texto disponível na Página data de novembro de $2013^{75}$, com título As raízes liberais do bolsa família. O texto sintetiza bem o propósito da Página, que é fortalecer o liberalismo (frequentemente usado como sinônimo de libertarianismo) em debates públicos.

Fundado pelos membros e ex-membros do EPL - Carlos André Góes, Pedro Menezes, Valdenor Júnior, Felipe Melo França e Mano Ferreira - o Mercado Popular define-se em seu manifesto por quatro macro afirmativas: 1. Nossa filosofia é a filosofia da humildade; 2. Nossa filosofia é contra todo tipo de uniformização ou segregacionismo; 3. Nossa filosofia busca maximizar o bemestar dos mais pobres; e 4. Nossa filosofia se baseia em paz e liberdade. 0 Manifesto dá o tom que tem sido, na maior parte dos textos, a linha do Mercado Popular: aproximar-se da construção de um conjunto de narrativas que defendam o libertarianismo como a melhor opção de paz social e de maximização do bem-estar dos mais pobres.

Por quase dois anos, o Mercado Popular manteve atuação restrita à arena virtual, que se excetuava pela participação em alguns eventos presenciais do EPL. Mais recentemente, o grupo se formalizou como instituto e deu uma guinada em seu projeto, conforme afirma seu atual CEO e também coordenador estadual do EPL em São Paulo, Gustavo Oliveira, em matéria no sítio eletrônico do $\mathrm{EPL}^{76}$ :

\footnotetext{
$75<$ http://mercadopopular.org/2013/11/as-raizes-liberais-do-bolsa-familia/>. Acesso em 23 de fevereiro de 2016.

${ }^{76}$ http://epl.org.br/2016/02/10/epl-entrevista-gustavo-oliveira/>. Acesso em 23 de fevereiro de 2016.
} 
O Mercado Popular tem planos ambiciosos para 2016. Primeiramente, deixaremos de ser apenas um blog com caráter left-libertarian, pois nos tornaremos um laboratório de políticas públicas. Ou seja, não seremos mais panfletários como já fomos um dia, pois a nossa pretensão é a de fazer com que o Mercado Popular vire um instituto sério e com pesquisas próprias. $O$ site continuará com os seus artigos normalmente, porém dando um caráter mais autoral, evitando que as nossas opiniões sejam enviesadas. Iremos atuar em três áreas: o instituto, o site e a editora.

Há que se fazer um contraponto, entretanto, à análise de Gustavo Oliveira. Ainda que se questionem os métodos, os textos do Mercado Popular são analíticos e buscam adicionar ao debate do campo político libertário no Brasil. Os textos do Mercado Popular têm sido um espaço privilegiado para membros e ex-membros do EPL produzirem debates, se destacando como um think tank da rede.

O Mercado Popular é, entre as três organizações da rede, a que menos arrecada e menos depende de recursos financeiros, conforme declara o Entrevistado 1. Com exceção do pagamento de publicidade no Facebook, de taxas de hospedagem e de registro de domínio, pouco ou nada de recurso financeiro consome a organização. Seus encontros presenciais são informais, conforme relata o Entrevistado 1, e têm ocorrido às expensas de cada participante.

Como informou o Entrevistado 5, o EPL está trabalhando para levantar recursos para o Mercado Popular e garantir a expansão de suas atividades. Atuando como um think tank associado ao EPL, o Mercado Popular contribui para fortalecer as formulações políticas da rede.

Com esses três nós, a Rede EPL possui um movimento de juventude e formação de quadros - EPL, um movimento de massas - MBL e um think tank - Mercado Popular. Faltaria a esse desenho uma estratégia de disputa das instituições pelas vias eleitorais.

Isso, entretanto, também já está sendo trabalhado com a fundação do Partido Novo e a criação de uma tendência no Partido Social e Liberal (PSL), chamada Livres. Uma parte dos dirigentes do EPL, como Juliano Torres e Marcel Van Hattem está construindo o Partido Novo. Outra parte dos dirigentes, a exemplo de Felipe Melo França e Fábio Ostermann, está construindo um projeto político 
dentro do Partido Social e Liberal, tentando transformar uma legenda fisiológica em um partido político programático.

Por ser um processo muito recente, com a indefinição de muitos possíveis participantes e em arenas disputadas com diversos outros grupos políticos, a construção dos partidos mencionados não entrou no escopo analítico dessa dissertação. Entretanto, é relevante que seja registrado que a estratégia política da rede EPL também alcança a dimensão partidária. Esse processo é recente e configura a abertura de novos horizontes políticos para a organização e a rede que constrói. 


\section{Capítulo 4 - Ferramentas Digitais e identidade na Rede EPL}

Como explicado no terceiro capítulo, a Rede EPL é composta por três organizações bastante distintas em propósito, mas que compartilham lideranças e se inserem dentro de uma mesma comunidade política - identificada no espectro da direita. Tanto o Instituto Mercado Popular como o Movimento Brasil Livre foram criados a partir do grupo Estudantes Pela Liberdade.

Como pressupostos básicos, a análise que se segue incorpora as noções de que as arenas virtuais de interação estão interconectadas com o mundo físico, reorganizando as dimensões espaciais e temporais da vida social (BARNETT, 2004); de que o conceito de formação de identidade constrói-se quebrando a dualidade entre estrutura e sentido (MELUCCI, 1996), e de que "a solidariedade tem muito a ver com interesse, mas ela só produz um movimento sustentado quando o consenso é construído em torno de significados e identidades comuns" (TARROW, 2009).

Esses pressupostos analíticos têm três implicações. A primeira é questionar o conceito de "realidade virtual" - uma dimensão existencial completamente apartada e sem conexão com a realidade física - como pressuposto empírico válido, pois, mesmo admitindo que as plataformas digitais permitam o anonimato e a criação de uma outra identidade, o comportamento de um indivíduo nelas impacta sobre sua percepção e ação no mundo físico.

A segunda é aceitar que não existem ações puramente utilitárias, nem ações puramente identitárias, já que se admite que o conceito de identidade quebra a dualidade entre estrutura e sentido. Uma campanha para levantamento de recursos ativa noções de solidariedade e pertencimento dos doadores a um grupo, da mesma maneira que o reconhecimento de indivíduos como parte de um grupo representa um recurso importante para essa organização política. Assim, identidade e recursos tornam-se dois elementos fungíveis, ao menos para a compreensão da natureza da ação comunicativa da organização.

A terceira implicação é compreender a construção de significados e identidades comuns como o centro da ação dos movimentos. Sem essa construção, o 
movimento se esvazia de conteúdo, perdendo sua legitimidade e sua capacidade de mobilizar recursos. Igualmente, sem significados e identidades comum, a solidariedade não consegue gerar ação política efetiva.

Os objetivos desse capítulo são compreender como os diferentes usos que cada organização faz do Facebook se conectam à sua identidade e aos seus objetivos estratégicos e mapear a rede virtual na qual as organizações se inserem. Para alcançar esses objetivos, o capítulo está dividido em três seções. Na primeira seção, comparo a identidade de cada organização, declarada no conteúdo das entrevistas e nas fontes documentais, com a análise do conteúdo de suas postagens no Facebook. Na segunda seção, faço uma descrição sobre a posição de cada organização no grafo produzido a partir da rede de curtidas de páginas do Facebook. Na terceira seção, faço uma breve análise sobre como as três organizações adotam estratégias diferentes para enfrentar o dilema coesãoexpansão.

\subsection{Auto-identificação, organização e estrutura}

As três organizações estudadas possuem algumas características em comum que as aproximam. Todas as três identificam-se como pertencentes ao espectro liberal-libertário, foram fundadas por lideranças do EPL e compartilham dirigentes entre si, jovens na faixa de 18 a 31 anos. As semelhanças, entretanto, são complementadas por algumas peculiaridades.

No que diz respeito aos objetivos, são três organizações com vocações diferentes. Enquanto o Movimento Brasil Livre pretende ser um movimento de massas, o grupo Estudantes Pela Liberdade atua como uma plataforma de formação de lideranças e de redes sociais. O Mercado Popular, por sua vez, atua como um think tank e se reestrutura para ser um instituto de pesquisa e de formulação de políticas públicas, talvez por acreditarem haver uma janela de oportunidade na conjuntura política brasileira.

Os objetivos das organizações carregam outra diferença associada - elas se dirigem a públicos distintos. Enquanto o EPL tem como foco declarado em seu sítio eletrônico a formação de estudantes, o Mercado Popular quer se dirigir a formadores de opinião e pessoas interessadas em política de uma maneira geral. 
Como declara o Entrevistado 7, o Mercado Popular quer melhorar a qualidade do "debate político" de uma maneira mais ampla. O Entrevistado 1, por sua vez, evidencia o interesse do MP em dialogar inclusive com um público que, de alguma maneira, se identifique com a esquerda, mas esteja aberto a outras ideias. O público do MBL, por outro lado, é muito mais amplo. Como informa o Entrevistado 5, a criação do grupo tinha o objetivo de dar uma direção aos protestos de Junho de 2013. Sobre a razão do grupo existir hoje, o Entrevistado 6 destaca o objetivo de massificar o movimento liberal, comunicando-se com o mais diverso público possível.

A forma de organização desses grupos também difere. Enquanto o EPL se organiza por meio de coordenações locais, estaduais e regionais, além de englobar grupos de diversas naturezas, como círculos de debate, coletivos do movimento estudantil e de juventude, o Movimento Brasil Livre se estrutura em células. Já o Mercado Popular é uma organização unitária, que não possui estrutura por critério de território, apesar de ter os seus membros bastantes dispersos espacialmente. Os encontros e reuniões do MP ocorrem quase que exclusivamente pela internet, conforme informado por seus dirigentes, Entrevistados 1 e 7.

A forma de recrutamento e acesso é outra diferença fundamental entre os grupos. O EPL busca ativamente identificar jovens que tenham abertura a suas ideias para inseri-los em sua rede. Trata-se de uma organização com divulgação ostensiva, mas com alguns mecanismos de seletividade, exigindo que os interessados sejam estudantes que se reconheçam dentro de seu espectro político, conforme informado pelos Entrevistados 3, 4 e 5. Reforçando esse filtro, as postagens e memes de recrutamento do EPL costumam incluir menções a valores liberais. No Movimento Brasil Livre, o processo de recrutamento é ainda menos seletivo buscando uma identidade mais aberta: se reconhecer como antipetista - um conceito elástico que abarca uma grande diversidade de posições políticas, inclusive a falta de preferências políticas claras. Além disso, o público-alvo do MBL não se restringe a jovens e inclui adultos e idosos. $O$ Mercado Popular, por outro lado, é uma organização fechada, que recruta pessoas com maior formação e acúmulo no debate liberal, o que implica em alto grau de identidade política com o Instituto. Trata-se de um processo de 
recrutamento a partir de suas redes de contato, próximo de um headhunting, sem processos públicos para entrada de membros.

A estrutura das organizações também é distinta, tendo o EPL em um extremo, com mais recursos e maior grau de profissionalização e, no outro extremo, o Mercado Popular, com trabalho completamente voluntário, parcamente financiado por seus membros ou por apoiadores individuais. O MBL, apesar de conseguir fundos para se financiar ${ }^{77}$, não tem o mesmo nível de treinamento, orientação e formalização de processo que tem o EPL. Como afirmou o Entrevistado 1, o MBL está se desenvolvendo na prática e, no caminho, vão cometendo erros que formam o acúmulo de aprendizado da organização, faltando a eles o treinamento e a institucionalização dos processos que já existe no EPL.

${ }^{77}$ Em uma medida que não é possível mensurar, já que a organização não dá publicidade a suas doações. 
Quadro 3-Quadro Resumo das diferenças organizacionais entre EPL, MBL e MP

\begin{tabular}{|c|c|c|c|c|}
\hline & Objetivos & $\begin{array}{l}\text { Forma de } \\
\text { organização }\end{array}$ & $\begin{array}{l}\text { Estratégia de } \\
\text { Recrutamento }\end{array}$ & Estrutura \\
\hline EPL & $\begin{array}{l}\text { Formar lideranças e } \\
\text { promover o } \\
\text { networking para } \\
\text { apoiar o } \\
\text { desenvolvimento de } \\
\text { suas jovens } \\
\text { lideranças }\end{array}$ & $\begin{array}{l}\text { Estruturada em } \\
\text { coordenações } \\
\text { hierarquizadas } \\
\text { territorialmente, } \\
\text { englobando coletivos } \\
\text { de diversas naturezas }\end{array}$ & $\begin{array}{l}\text { Aberto e } \\
\text { seletivo }\end{array}$ & Profissionalizada \\
\hline MBL & $\begin{array}{l}\text { Derrubar o PT e } \\
\text { massificar o } \\
\text { movimento liberal }\end{array}$ & $\begin{array}{l}\text { Estruturada por meio } \\
\text { de células locais, com } \\
\text { uma direção central } \\
\text { em São Paulo }\end{array}$ & Aberto & $\begin{array}{l}\text { Semi- } \\
\text { profissionalizada }\end{array}$ \\
\hline MP & $\begin{array}{l}\text { Difundir ideias, } \\
\text { atitudes, estudos e } \\
\text { políticas públicas } \\
\text { para promover o } \\
\text { liberalismo e, por } \\
\text { meio dele, o bem- } \\
\text { estar dos mais } \\
\text { pobres }\end{array}$ & $\begin{array}{l}\text { Unitária e virtual, sem } \\
\text { sede física. }\end{array}$ & Fechado & Voluntária \\
\hline
\end{tabular}

Fonte: elaboração própria.

$\mathrm{Na}$ análise sobre os usos que fazem da página oficial no Facebook, busquei entender em que medida estes refletem as diferenças resumidas no quadro 2. Outras características que poderiam influir, como faixa etária/geração, orientação política, perfil socioeconômico e origem pré ou pós-digital estão controladas, já que se trata de três organizações surgidas a partir de 2008, que se encontram no espectro político da Direita e cujas lideranças têm a mesma faixa etária e origem socioeconômica semelhante.

A tabela e os gráficos a seguir mostram, conforme explicado no Capítulo 1, quais foram em quais categorias melhor se encaixam as postagens de cada organização entre janeiro de 2014 e dezembro de 2015. Os dados estão 
agregados, sem distribuição em série temporal. Essa classificação ajuda a elucidar a relação entre os processos de formação de identidade e a estratégia de comunicação adotada pelas organizações.

Tabela 1 - Publicações dos administradores nas páginas do Facebook por categoria x organização (2014-2015)

\begin{tabular}{|l|r|r|r|r|r|r|}
\hline Categoria da Publicação & MP & MP (\%) & EPL & EPL(\%) & MBL & MBL(\%) \\
\hline Agitação & 250 & $22,91 \%$ & 575 & $24,95 \%$ & 1025 & $19,68 \%$ \\
\hline Critica Anti-PT & 175 & $16,04 \%$ & 138 & $5,99 \%$ & 1479 & $28,40 \%$ \\
\hline Crítica outros & 232 & $21,26 \%$ & 204 & $8,85 \%$ & 498 & $9,56 \%$ \\
\hline Debate público & 166 & $15,22 \%$ & 281 & $12,19 \%$ & 43 & $0,83 \%$ \\
\hline Demarcação & 56 & $5,13 \%$ & 235 & $10,20 \%$ & 57 & $1,09 \%$ \\
\hline Levantamento de recursos & 6 & $0,55 \%$ & 59 & $2,56 \%$ & 721 & $13,84 \%$ \\
\hline Mobilização & 61 & $5,59 \%$ & 344 & $14,92 \%$ & 403 & $7,74 \%$ \\
\hline Networking & 39 & $3,57 \%$ & 69 & $2,99 \%$ & 62 & $1,19 \%$ \\
\hline Protesto & 0 & $0,00 \%$ & 4 & $0,17 \%$ & 830 & $15,94 \%$ \\
\hline Recrutamento próprio & 1 & $0,09 \%$ & 340 & $14,75 \%$ & 64 & $1,23 \%$ \\
\hline Recrutamento terceiros & 8 & $0,73 \%$ & 7 & $0,30 \%$ & 2 & $0,04 \%$ \\
\hline Solidariedade nacional & 1 & $0,09 \%$ & 20 & $0,87 \%$ & 6 & $0,12 \%$ \\
\hline $\begin{array}{l}\text { Solidariedade } \\
\text { transnacional }\end{array}$ & 1 & $0,09 \%$ & 21 & $0,91 \%$ & 12 & $0,23 \%$ \\
\hline Indisponível & 25 & $2,29 \%$ & 0 & $0,00 \%$ & 3 & $0,06 \%$ \\
\hline Outros & 70 & $6,42 \%$ & 8 & $0,35 \%$ & 3 & $0,06 \%$ \\
\hline Total & $\mathbf{1 0 9 1}$ & $\mathbf{1 0 0}$ & $\mathbf{2 3 0 5}$ & $\mathbf{1 0 0}$ & $\mathbf{5 2 0 8}$ & $\mathbf{1 0 0}$ \\
\hline
\end{tabular}

Fonte: elaboração própria om base nos dados extraídos das páginas das organizações utilizando o Netvizz 
Figura 4 - Categorias de publicação por organização

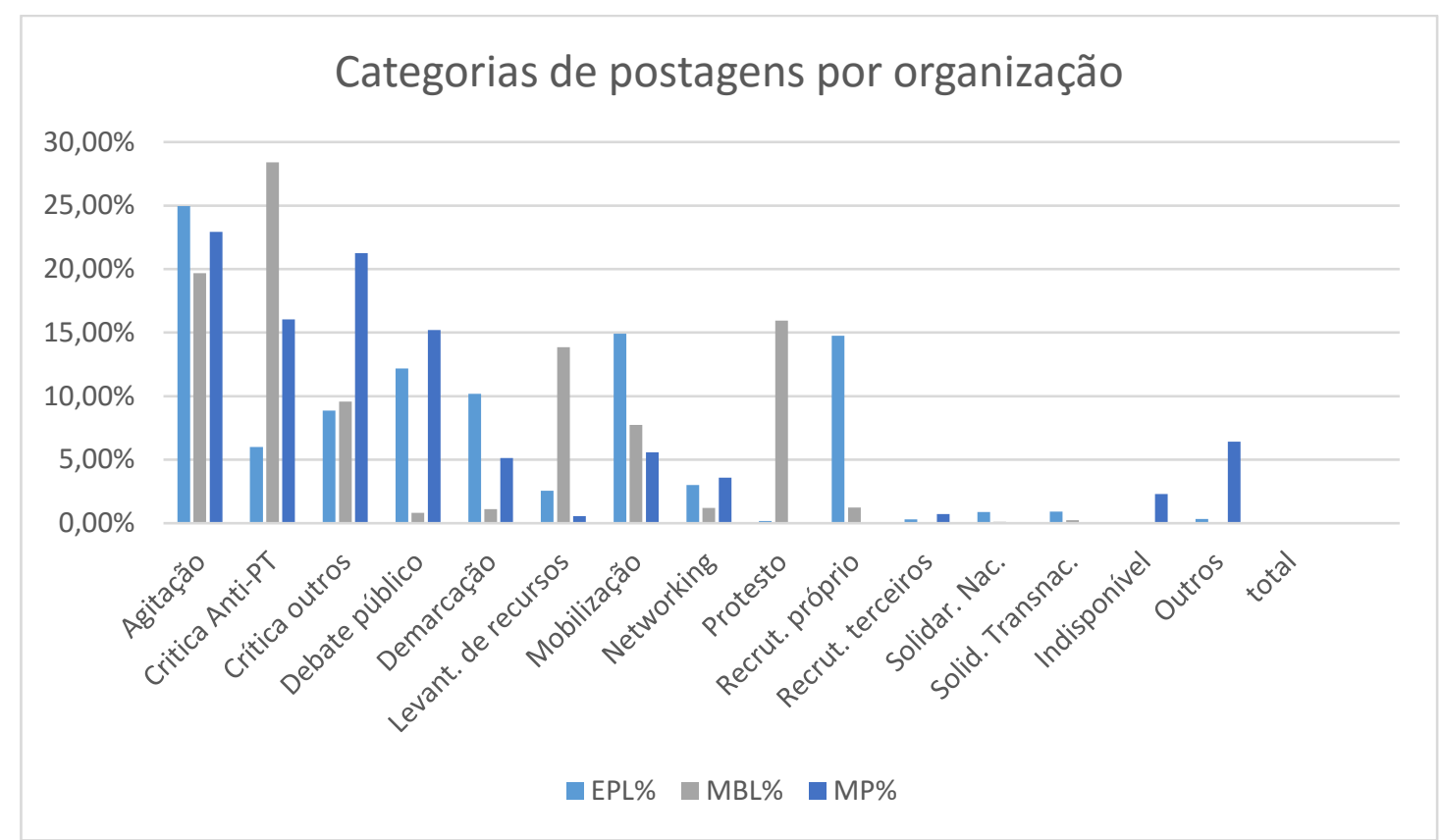

Fonte: elaboração própria com base nos dados extraídos das páginas das organizações utilizando o Netvizz 
Figura 5 - Categorias das publicações dos administradores na página do Facebook do EPL

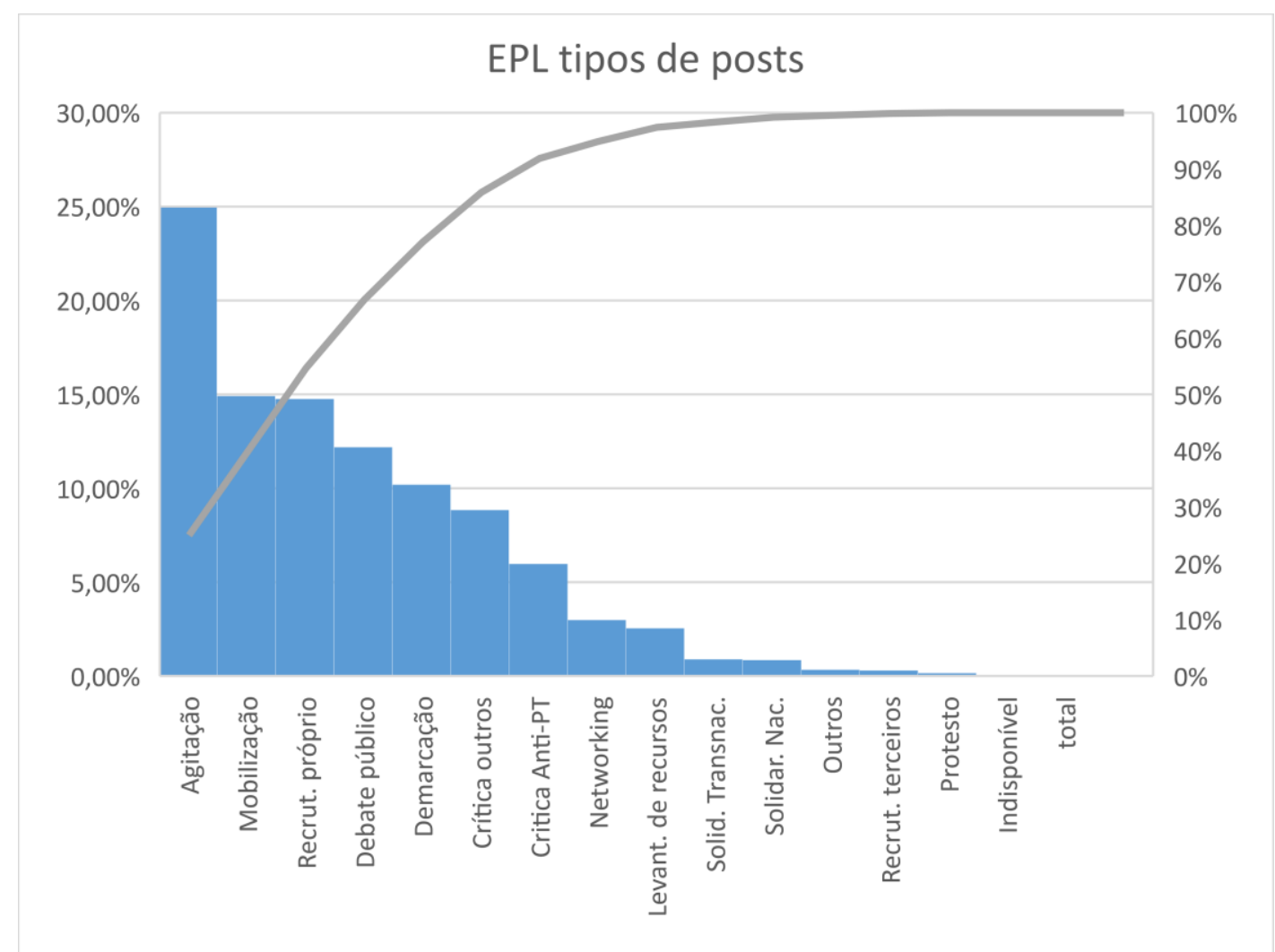

Fonte: elaboração própria om base nos dados extraídos das páginas das organizações utilizando o Netvizz

Figura 6 - Categorias das publicações dos administradores na página do Facebook do MBL

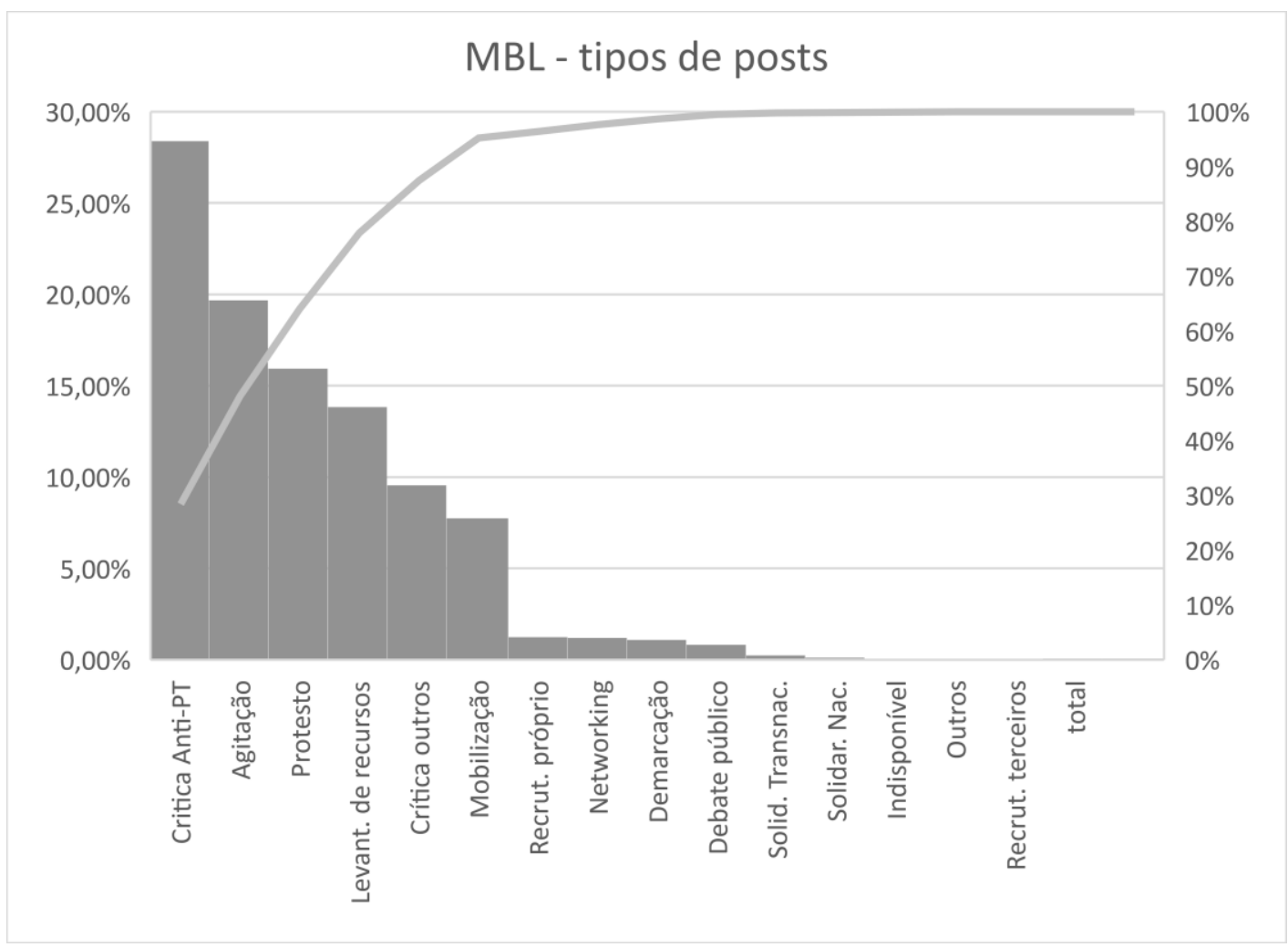

Fonte: elaboração própria om base nos dados extraídos das páginas das organizações utilizando o Netvizz 


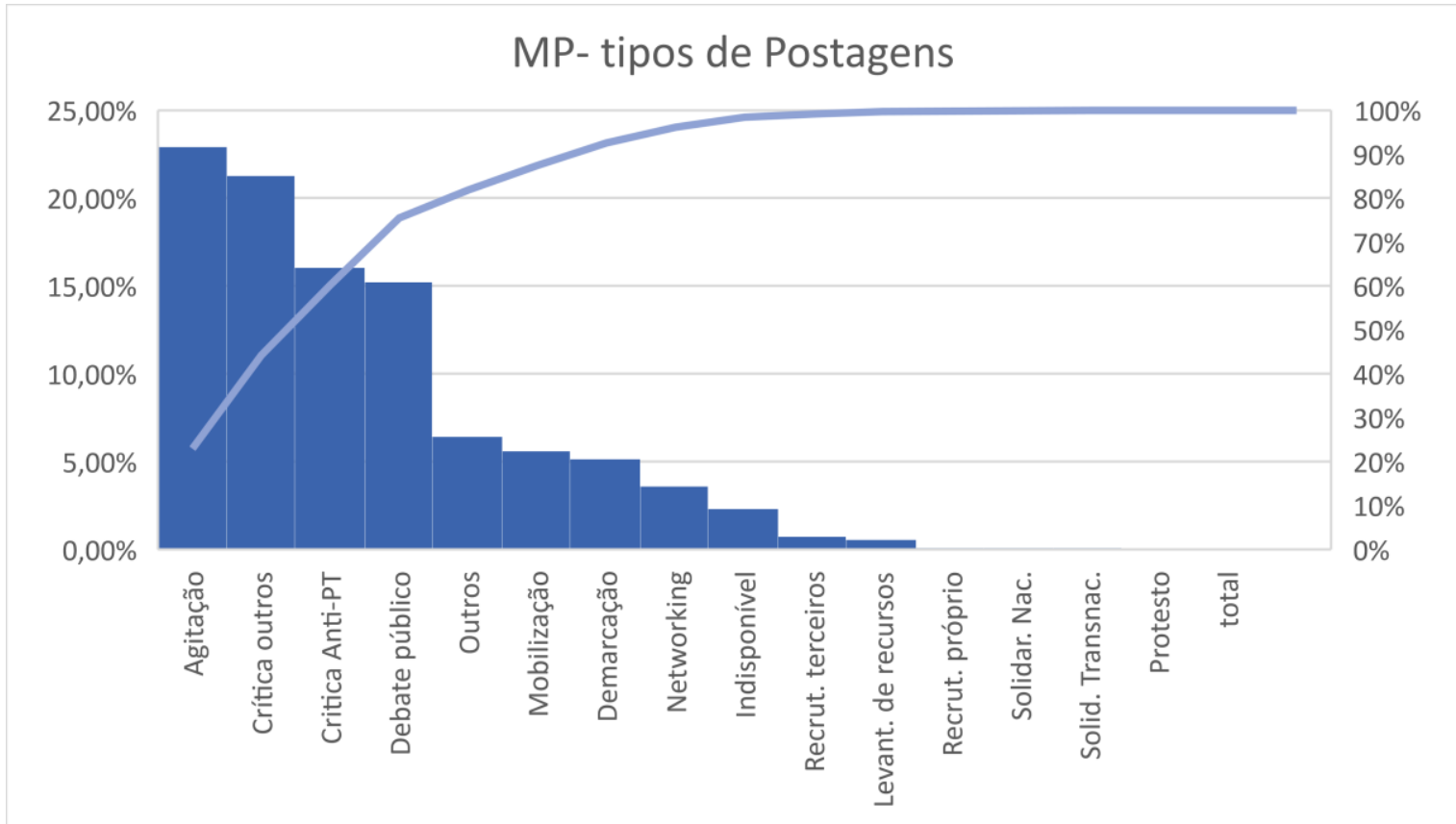

Fonte: elaboração própria om base nos dados extraídos das páginas das organizações utilizando o Netvizz

A análise de conteúdo das postagens das três organizações revela que todas elas dedicam uma grande proporção de seus esforços em agitação e propaganda do próprio trabalho (EPL- 24,95\%, MBL- 19,68\%, MP- 22,91\%,), mas o principal elemento que o MBL utiliza para construir sua identidade nas mídias sociais é o antipetismo. Quase metade dos posts $(44,34 \%)$ do MBL tem como finalidade a crítica ao PT ou a convocação para protestos contra o PT, o que implica que, pelo menos na página do Facebook, a apresentação da identidade do MBL se dá mais por oposição ao PT do que por afirmação de programa, projeto ou ideias próprias. Em poucas postagens $(1,09 \%)$, o MBL buscou fazer alguma diferenciação em relação às outras organizações de direita que fazem oposição ao governo. Trata-se da organização que apresenta sua identidade com o menor grau de afirmação entre as três estudadas, ou seja, a que se apresenta com uma comunicação mais aberta e mais flexível. Essa característica é bastante coerente com o perfil que a organização busca construir, de mobilizar de grandes setores da população.

No que se refere ao conteúdo, ainda que sem fazer um esforço para quantificar o tipo de linguagem utilizada, é possível notar que o MBL usa de muita ironia, sarcasmo e agressividade em seus posts. Além disso, realiza pouco debate público $(0,83 \%)$, características que o diferencia do EPL e do MP, que, além de 
produzirem seus posts com linguagem mais sóbria e argumentativa, também se empenham mais no debate público - 12,19\% e 15,22\%, respectivamente.

O EPL é a organização que mais se utiliza de categorias afirmativas - como agitação e propaganda, mobilização para atividades, recrutamento e debate público (66,81\% acumulado) - para apresentar sua identidade. O Mercado Popular, por outro lado, dedica parte importante do espaço da página à crítica à esquerda não petista $(21,26 \%)$ e ao PT $(16,04 \%)$, mesmo que também realize debate público $(15,22 \%)$ e faça agitação e propaganda de sua organização $(22,91 \%)$.

Conforme afirmou o Entrevistado 1, o Mercado Popular tem inspiração no Bleeding Heart Libertarians ${ }^{78}$, ou seja, se identifica mais à esquerda no espectro político libertário e busca afirmar o livre mercado como caminho para a promoção da justiça social. Possivelmente como consequência disso, suas postagens estejam mais voltadas a se fortalecer por meio da diferenciação com a esquerda.

Das três organizações, o EPL é a que mais claramente utiliza a página do Facebook para apresentar sua identidade por meio da diferenciação com outros grupos e tendências da direita. Em sua maioria, os posts demarcatórios contêm posicionamentos contra o punitivismo, o machismo, o elitismo, o proibicionismo e o fisiologismo na direita. Raramente esses posts demarcatórios do EPL identificam nominalmente as organizações ou partidos que possuem essas práticas.

Outros elementos importantes que emergiram da análise das postagens foram a forma como se realiza o levantamento de fundos pelo MBL e o empenho do Mercado Popular no processo seletivo do EPL. Ao realizar pedidos de doações, o MBL frequentemente identifica as contribuições financeiras como uma forma de engajamento militante na derrubada do PT, construindo um vínculo identitário entre os doadores e o MBL. Como organizações de um mesmo campo político tendem a disputar militantes entre si, foi bastante significativo identificar algumas postagens do Mercado Popular promovendo o processo seletivo do EPL. Isso

\footnotetext{
${ }^{78}$ Tendência política norte-americana que busca aliar valores de livre mercado com justiça social. Para mais informações ver http://bleedingheartlibertarians.com/
} 
tem como pano de fundo não apenas o compartilhamento de dirigentes em comum, mas também a associação de identidade entre as duas organizações. Além disso, o MP não realiza recrutamento público e é um potencial beneficiário dos quadros formados pelo EPL, razão pela qual aparenta não haver disputa por militantes entre essas organizações.

\subsection{Rede EPL: análise gráfica a partir da rede de curtidas no Facebook}

A análise de redes de curtidas entre páginas do Facebook serve, no escopo desta pesquisa, para complementar a análise empírica apresentada. Mais especificamente, ela ajuda a compreender como estão estruturadas as comunidades virtuais. As redes são construídas pela extração de dados sobre as curtidas entre as páginas e informam medidas importantes sobre a natureza das redes virtuais de cada organização.

Cada nó desenhado nos grafos de rede representa uma página e cada aresta simboliza uma curtida. Uma aresta pode ser unidirecional, caso apenas uma página curta a outra, ou bidirecional, caso a curtida seja mútua. O tamanho de cada nó, nesta pesquisa, é dado pelo grau de entrada, ou seja, é proporcional ao número de arestas que este nó recebe, ou seja, exclusivamente às curtidas que recebe dentro da rede ilustrada.

$\mathrm{Na}$ extração de dados, são obtidas somente as páginas, excluindo-se os perfis, pois quando um perfil curte uma página, ele pode fazê-lo não por identidade, mas para que as publicações dessa página possam ser expostas em seu feed de notícias. Isso significa que um usuário pode curtir uma página simplesmente para ser atualizado das coisas que esta posta, sem ter qualquer identidade com a página.

Como uma página possui apenas o mural de publicações, sem feed ${ }^{79}$, a curtida tem uma simbologia diferente e é medida relacional mais segura em que uma página reconhece estar conectada a outra. Por isso, o grafo de rede de curtidas

${ }^{79}$ Em outras palavras, os administradores da página não veem as publicações das páginas que curtiram. A curtida de uma página por outra é meramente um ato de conexão e prestígio. 
permite uma análise sobre identidade por meio do reconhecimento de clusters ou comunidades, mas apenas se aplicado a páginas.

Para a identificação de um cluster, o software utilizado [Gephi] calcula a densidade de uma rede - a quantidade de conexões em relação ao número total de conexões possíveis - e identifica os nós que compartilham o maior número de conexões entre si (RECUERO, 2014), por meio de um algoritmo que revela a estrutura de rede comunitária hierarquizada com alto grau de confiabilidade (BLONDEL et al., 2008). O processo de extração da rede de curtidas em dois níveis resultou nos seguintes dados:

Quadro 4 - Resultado da extração de dados da rede de curtidas em 12 de fev de 2016

\begin{tabular}{|l|l|l|l|l|}
\hline $\begin{array}{l}\text { Nó- } \\
\text { semente }\end{array}$ & № de nós & № de arestas & $\begin{array}{l}\text { № de } \\
\text { comunidades }\end{array}$ & Densidade \\
\hline EPL & 292 & 1696 & 9 & 0,02 \\
\hline MBL & 276 & 1191 & 6 & 0,016 \\
\hline
\end{tabular}

Fonte: elaboração própria

O que a extração de dados inicial demonstra é que a página do EPL possui uma rede mais extensa e mais densa, apesar de formar maior número de comunidades. Esses dados, entretanto, não podem ser isolados e precisam ser analisados considerando o grau de centralidade dessas páginas estudadas medido pela sua posição como intermediador entre páginas e pela proximidade em relação às demais páginas - e pelo seu grau de autoridade - medido pela sua relevância e popularidade e pela sua capacidade de referenciar e conectar outros nós relevantes e populares.

Como a página do Mercado Popular não curtia nenhuma outra página ao momento da extração, não foi possível fazer uma análise de sua rede ego ou egocentrada ${ }^{80}$. Dessa maneira, a análise da identidade do Mercado Popular a

${ }^{80}$ Rede ego ou egocentrada é a rede formada tomando um determinado nó como ponto de partida e centro da análise. A partir dele, coletam-se os dados em até dois graus de separação. 
partir das comunidades em que se insere será feita somente considerando sua posição na rede ego do EPL.

Cabe ressaltar que as medidas de modularidade e clusterização que localizam os grupos na rede mapeada avaliam como os nós estão conectados, mas não avaliam a qualidade dessas conexões, cabendo, por isso, um esforço interpretativo e medidas qualitativas adicionais (RECUERO, 2014). Nesse sentido, a análise sobre a rede em torno da Página do Mercado Popular será menos expressiva do que a análise das demais redes, já que partirá da Rede Ego de outra organização.

Também relevante é a posição dos nós no gráfico, que não é dada aleatoriamente, mas definida por meio de um logaritmo que aproxima ou afasta os nós em um modelo inspirado nas leis da gravidade, em que o número de conexões compartilhadas e o tamanho de cada nó são as variáveis centrais. Dessa maneira, a posição de um nó depende de suas conexões com outros nós, de seu próprio tamanho e do tamanho dos nós com os quais mantém conexão. 
Conforme o Gráfico abaixo, o logaritmo de modularidade (BLONDEL et al., 2008) encontrou nove comunidades na Rede EPL, identificadas nas seguintes cores:

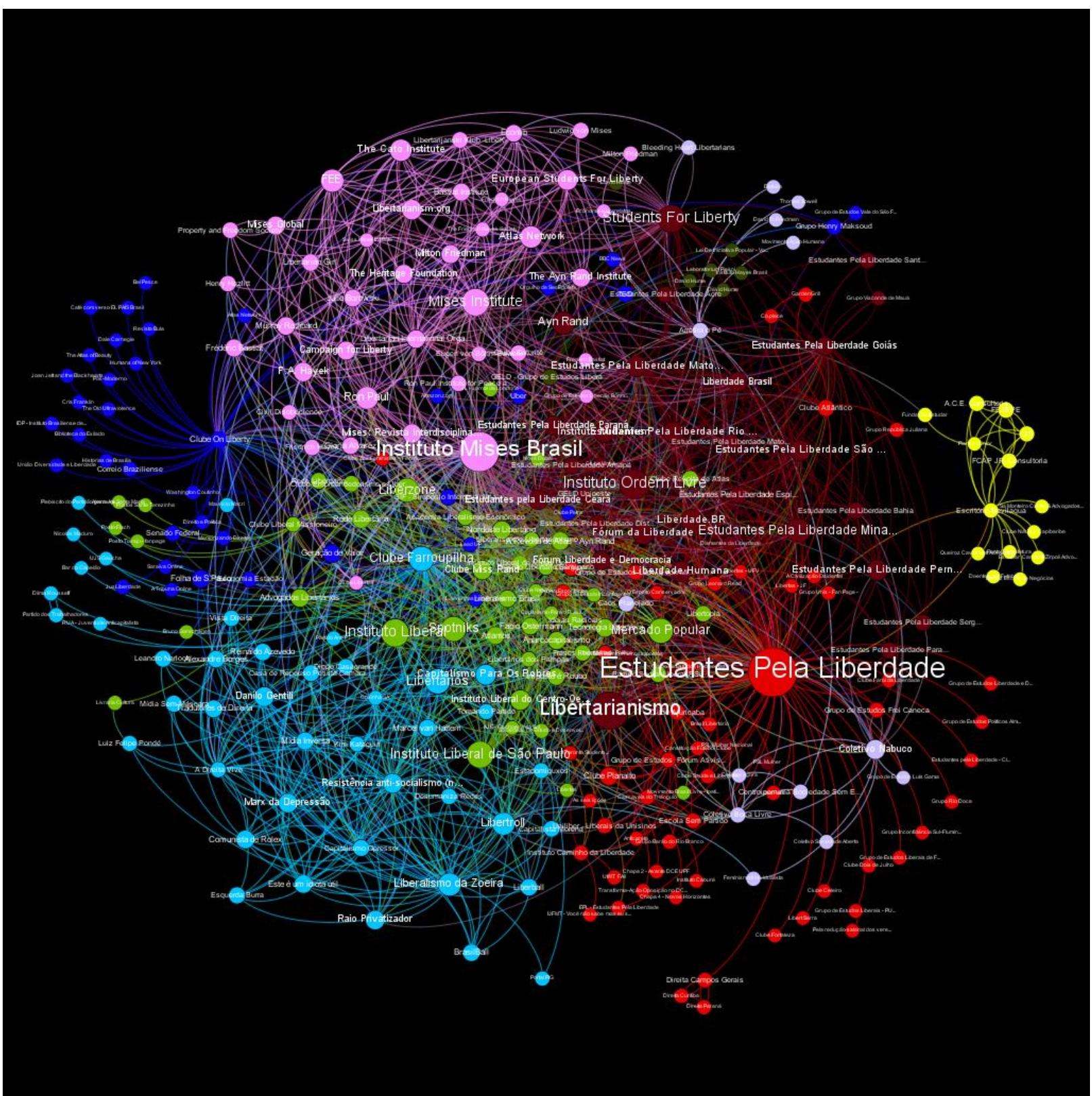

Fonte: elaboração própria com uso dos softwares livre Netvizz e Gephi

Em vinho: cluster composto pela maior parte dos capítulos estaduais do EPL, pela página internacional Students For Liberty e pelo Portal Libertarianismo fundado por Juliano Torres, diretor executivo do EPL. 
Em vermelho: cluster composto pelo nó ego Estudantes Pela liberdade e pelos coletivos e grupos satélites do EPL - como os Clubes Celeiro, Planalto e Fortaleza, além de diversos outros clubes, grupos de estudo e chapas de DCE.

Em verde: cluster composto majoritariamente por think tanks, como o Mercado Popular, Institutos Liberais e por páginas de opinião, como Spotniks e Liberzone, além das páginas do Partido Social e Liberal (PSL) e de Fábio Ostermann, destacado formulador político e liderança da rede liberal-libertária.

Em Lilás: cluster composto por organizações filantrópicas financiadas pelos irmãos Koch - como The Cato Institute, Atlas Network e The Heritage Foundation - além de páginas de personalidade políticas como Ron Paul e Glória Alvarez.

Em Azul Claro: cluster composto por páginas de humor, sátiras, ironia e sarcasmo - como Raio Privatizador, Comunista de Rolex, Capitalismo Opressor, Marx da Depressão e Capitalismo para os Pobres - e por colunistas-ativistas figuras públicas, como Reinaldo Azevedo, Luiz Felipe Pondé, Kim Kataguiri e Marcel Van Hattem.

Em prata: pequeno cluster composto por grupos libertários identificados mais à esquerda - como o Coletivo Nabuco, Feminismo Libertário e Bleeding Heart Libertarians - e pela página do grupo liberal de estudantes do ITA, denominada Arretira o pé, que aparenta ser um outlier desse grupo.

Em verde musgo: pequeno cluster formado a partir de curtidas do Grupo de Estudos Liberalismo e Democracia, que inclui páginas dedicadas ao autor David Hume e também uma lei de iniciativa popular para o voto impresso, dentre outras.

Azul escuro: cluster mais afastado do gráfico - aproximada para facilitar a visualização -, criada a partir das curtidas do Clube On Liberty, inclui diversos veículos da imprensa - como Folha de São Paulo, Correio Braziliense, e Estadão.

Em amarelo: outro cluster que está afastado e foi aproximado para facilitar a visualização gráfica. É composto por escritórios de advocacia, por empresas juniores e pela Fundação Estudar. 
Como a análise gráfica indica, O EPL é composto por uma complexa rede de capítulos e coletivos de diversas natureza, que atuam em proximidade com Think Tanks, fundações, institutos e diversas figuras públicas. A rede internacional do grupo, a partir da organização brasileira, é bastante expressiva, refletindo a natureza transnacional da organização.

Bastante próximo ao EPL e conectado a outros Think Tanks, encontra-se o Instituto Mercado Popular. Também está representado graficamente 0 movimento de aproximação do EPL e do MP ao Partido Social e Liberal, como informado em entrevista. Entre os ativistas e organizações políticas, denota-se tratar de uma rede dentro do espectro da direita brasileira, mas afastada de partidos icônicos da direita mainstream brasileira, como o Democratas e o PSDB. 
4.2.2 Rede MBL: análise gráfica a partir da rede de curtidas no Facebook

Aplicando-se os mesmos procedimentos da análise anterior, foi criado o gráfico da rede ego do MBL, que possui 6 clusters identificados nas seguintes cores:

Figura 9 - Gráfico da rede de curtidas a partir do MBL em 12/02/2016

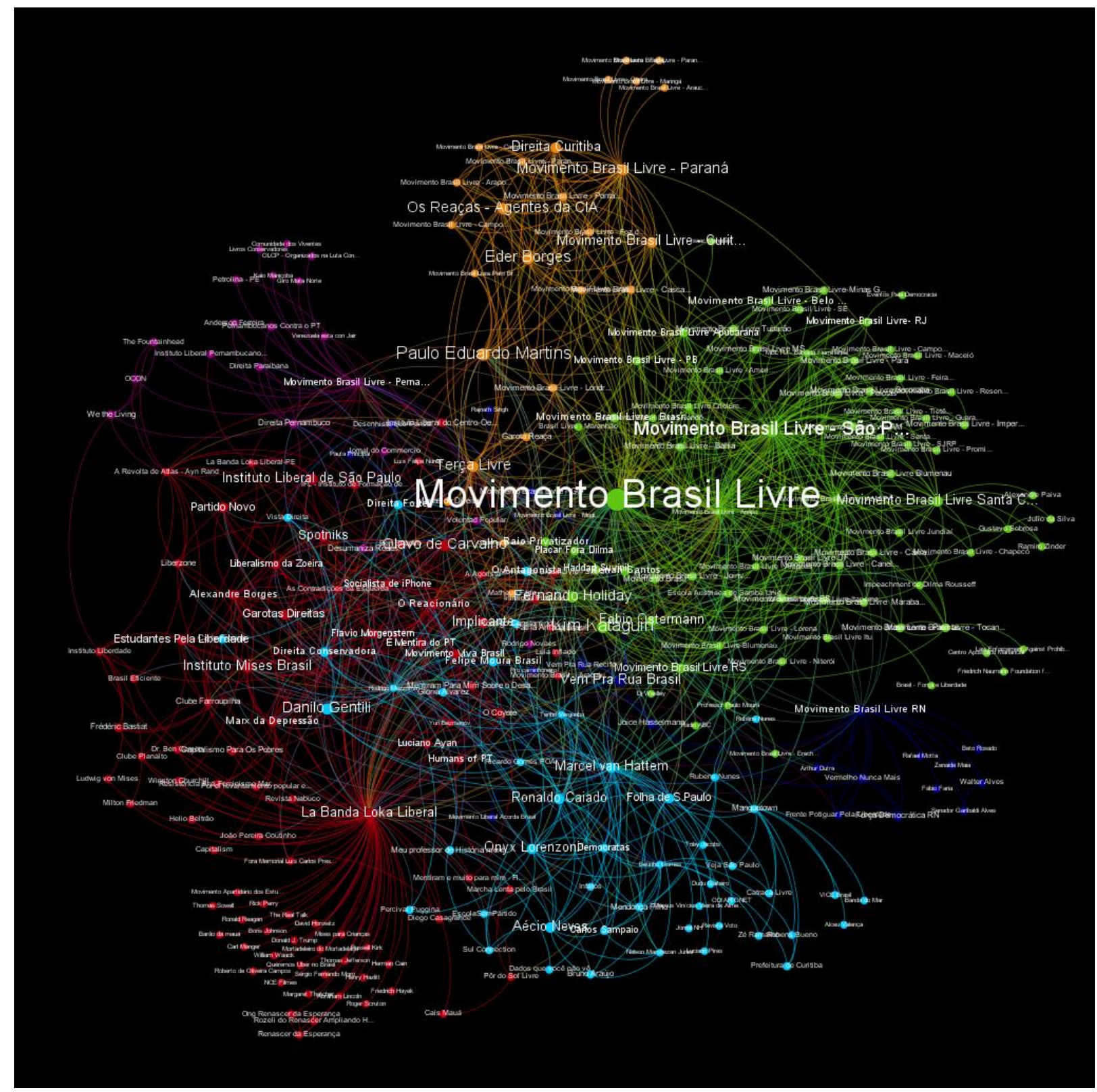

Fonte: elaboração própria com uso dos softwares livre Netvizz e Gephi

Em vermelho: cluster composto principalmente por coletivos políticos, páginas satíricas e think tanks do movimento liberal-conservador, além de algumas personalidades políticas. Nele, encontram-se a Banda Loka Liberal, o EPL, diversos coletivos associados ao EPL, os Institutos Liberais, o Instituto Mises Brasil e páginas como o Reacionário, Liberzone e Spotnik, além do Partido Novo e de páginas de ativistas políticos como Olavo de Carvalho, Flávio Morgenstern 
e Alexandre Borges. Trata-se do maior cluster e é bastante representativo da direta brasileira mais programática, incluindo liberais, conservadores e libertários.

Em verde: cluster composto pela maior parte das células do MBL (excetuandose as do Paraná, Rio Grande do Norte e Pernambuco) e pelos seus principais dirigentes e figuras públicas, incluindo Renan Santos, Kim Kataguiri, Fábio Ostermann e Fernando Holiday.

Em azul claro: cluster composto principalmente por políticos e partidos da direita mais institucionalizada. Engloba a página do Partido Democratas e de políticos como Onyx Lorenzoni (DEM), Ronaldo Caiado (DEM), Mendonça Filho (DEM), Aécio Neves (PSDB), Bruno Araujo (PSDB), Carlos Sampaio (PSDB) e Marcel Van Hattem (PP). Também estão nele páginas de veículos de comunicação como Folha de São Paulo e Veja São Paulo, além de colunistas conservadores, como Felipe Moura Brasil e Rodrigo Constantino.

Em roxo: cluster composto pela rede do $\mathrm{MBL}$ em Pernambuco, englobando a célula do Movimento no estado, além de páginas como Pernambuco contra o PT, Direita Pernambuco e Organizados na Luta contra a Corrupção - Petrolina. Também estão em conexão à direita com a Venezuela, por meio de páginas como Voluntad Popular e Venezuela está con Jair, esta última administrada por brasileiros, que também constituem a maior parte de sua audiência ativa ${ }^{81}$.

Em laranja: cluster composto pela rede do MBL no Paraná. Engloba mais de uma dezena de células do movimento no estado, além de páginas de figuras públicas como o Deputado Paulo Eduardo Martins (PSDB/PR) e o ativista Eder Borges.

Em azul escuro: cluster composto pela rede do MBL no estado do Rio Grande Norte, que inclui a Frente Potiguar pela Liberdade, a Frente Democrática - RN e diversos políticos do estado, como o senador Garibaldi Alves (PMDB) e os deputados Beto Rosado (PP), Rafael Motta (PSB), Walter Alves(PMDB) e

81 Por audiência ativa, me refiro somente à audiência que interage com a página, curtindo, comentando e compartilhando. 
Zenaide Maia (PR). Também está nesse cluster, ainda que deslocado ao centro mais próximo de outros clusters, o movimento Vem Pra Rua.

As duas redes, apesar de mobilizarem muitos atores em comum, apresentam algumas diferenças importantes. Enquanto o EPL tem mais conexões com , coletivos e páginas de humor, o $\mathrm{MBL}$ se relaciona com um número grande de parlamentares do PSDB e do DEM. No que se refere às ligações partidárias, apenas o Partido Novo e o PSL aparecem na rede do EPL, enquanto a rede do MBL inclui diversos outros partidos, como PP, PMDB e PSB, além dos citados DEM e PSDB.

Outro aspecto relevante é que a rede formada a partir das curtidas do MBL apresentou clusters com clivagens territoriais e por tipos de atores, enquanto a rede formada a partir das curtidas do EPL apresentou clusters por clivagem ideológica e por tipos de atores. Isso parece estar associado às dinâmicas das organizações. Com extensa agenda de conferências e debates ${ }^{82}$, o EPL faz mais eventos presenciais em nível nacional do que o MBL e também tem mais atividades e campanhas de formação, o que tende a fortalecer uma coesão na identidade e a reduzir a clivagem territorial.

\subsection{Análise dos resultados}

A análise gráfica das redes de curtidas reforça a constatação do trabalho empírico ao evidenciar que a rede formada em torno do $\mathrm{MBL}$ reúne setores mais amplos da sociedade, sendo mais diversa do que a rede do EPL, mas também menos consistente ideologicamente. Para expandir-se e acumular forças em torno de seu projeto, o MBL precisa reduzir os requisitos identitários de forma que consiga atrair grupos e indivíduos menos alinhados ideologicamente com suas propostas, o que possivelmente tenha relação com o Entrevistado 6 identifica como a necessidade de se garantir que a estética seja capaz de massificar a organização.

82 O EPL realiza, além de sua Conferência Nacional, seminários de formação de lideranças e reuniões de seu corpo dirigente, diferente do $\mathrm{MBL}$, que realizou apenas um congresso nacional em novembro de 2015 - ver https://juventudemsp.wordpress.com/2016/01/20/juventudedemocratas-sao-paulo-participa-do-10-congresso-nacional-do-movimento-brasil-livre/ . 
Enquanto a rede ego do EPL é mais transnacional e possui mais conexões com think tanks, coletivos e institutos, a rede ego do MBL tem mais conexões com políticos, partidos, colunistas e veículos de comunicação, apresentando também mais recortes regionais do que a rede ego do EPL.

A estratégia de construção de identidade usada pelo MBL no Facebook é bastante útil à expansão do movimento, mas pode gerar um problema interno de baixa coesão identitária. A narrativa do movimento atrai uma audiência que se identifica com o antipetismo e participa de maneira mais livre e com menos organicidade do movimento, mas não necessariamente coaduna com um projeto mais amplo - como a privatização de serviços públicos e a redução do Estado , que são bandeiras do movimento.

Quando o antipetismo começar a decrescer, o MBL terá que desenvolver outras formas de engajamento e outras estratégias de construção de identidade para continuar mobilizando sua base militante e sua audiência menos orgânica. Conforme indica Tarrow (2009),

à medida que uma forma particular de organização coletiva enfraquece e as pessoas se cansam do confronto, os organizadores têm incentivos para desenvolver novas formas, atrair novos participantes ou radicalizar suas interações com opositores.

Nesse sentido, se não se reinventar e construir outras finalidades e projetos políticos, o MBL pode desaparecer com o fim do antipetismo, que estrutura sua identidade.

Uma das construções alternativas que o movimento está ensaiando é a entrada na política institucional por meio da disputa das eleições municipalistas em 2016. Entretanto, se não construir uma identidade política mais bem definida, o movimento pode não conseguir garantir o compromisso e a coesão necessários para se manter relevante e com capacidade de mobilização.

O Mercado Popular, por outro lado, já está em processo de reformulação identitária, como informou o Entrevistado 1, reduzindo a sua atuação como think tank apoiado na crítica a setores de oposição de esquerda e do governo petista para se tornar um Instituto de formulação de políticas públicas, investindo em 
estudos e propostas de maior profundidade - apresentados em forma de policy papers.

O EPL, de outro modo, se constrói por meio de comunicação com linguagem mais sóbria, por meio da agregação de valor à organização, por meio do debate público e por meio de diversas atividades presenciais formativas e de disputa de aparelhos do movimento estudantil, o que fortalece a identidade da organização e a unidade entre seus membros. Nesse sentido, apesar de a estratégia de construção política do EPL ser limitada por não permitir uma "massificação do movimento liberal", conforme postulado pelo Entrevistado 6, ela tende a ser mais consistente, por se basear em um processo de formação de identidade que cria mais vínculos e coesão. 


\section{Conclusão}

Ao analisar a criação da Peacenet por quatro organizações norte-americanas, Downing (1989) constatou o surgimento de um conjunto de facilidades que a internet e a computação trariam para a organização e a atuação política de movimentos sociais e ONGs. Desde então, as transformações tecnológicas se intensificaram e foram incorporadas pela população de uma maneira que ele não pôde prever.

O avanço tecnológico e a disseminação das ferramentas computacionais e da internet também foram acompanhados pelo crescente interesse de pesquisadores no impacto das tecnologias emergentes, em especial das redes sociais virtuais, sobre o cotidiano dos movimentos sociais. Isso inclui a emergência de diferentes repertórios de ação, processos de formação de identidade e formas de organização interna.

É nesse campo de estudo, marcado por um objeto tão fluido e mutável, mas impactante sobre o cotidiano social, que a presente dissertação se insere. Este trabalho ajuda a compreender de que maneira as redes sociais virtuais servem não apenas como ferramenta de ação política, mas de apresentação e reconhecimento de identidade, dando ênfase ao dilema sobre construir identidades mais definidas, mas com penetração social restrita (coesão), de um lado, ou ampliar a audiência e a alcance da organização, mas com baixa unidade identitária (expansão), de outro.

A pesquisa se concentrou no estudo de caso do que denomino de Rede EPL, um conjunto formado por três organizações relativamente autônomas - o grupo Estudantes Pela Liberdade, o Movimento Brasil Livre e o Instituto Mercado Popular - que compartilham dirigentes e foram criadas no âmbito do EPL. Agregada a essa rede, encontra-se uma série de coletivos satélites vinculados às lideranças locais do EPL, que foram excluídos do foco da presente análise.

A análise realizada evidenciou como, para além de criar instrumentos de ação e de articulação política, os usos das plataformas digitais impactam na formação de identidade, mas também são diretamente impactados por ela. Como resultado da interação virtual entre indivíduos e/ou organizações, surgem 
identidades que podem resultar em comunidades e organizações políticas, o que - no exemplo do EPL - ocorreu ainda na era do Orkut e possibilitou a conexão entre grupos e indivíduos dispersos no território brasileiro.

Outro achado importante da presente pesquisa diz respeito à disputa de narrativas nas plataformas digitais sobre os elementos da identidade do EPL. Apesar de ser claramente uma organização internacional, o EPL no Brasil busca não ser conhecido assim e, para isso, faz algumas construções e omissões em que se dissocia de sua sede nos Estados Unidos. Essa estratégia permite compreender a construção de narrativas nas mídias sociais também como um elemento de formação identitária em que as organizações buscam, por meio da imagem projetada no público, obter capital simbólico (BOURDIEU, 1977) ao se evidenciar como um grupo que se projetou com esforço e projeto próprios, ao mesmo tempo em que tentam não perder o lugar de fala privilegiado (FRANÇA, 2005), como um grupo nacional que aborda problemas nacionais a partir da perspectiva local, sem uma percepção colonialista.

É possível compreender também que, sem ser conhecida como uma organização internacional com sede nos Estados Unidos e vinculada ao grupo político financiado pelos irmãos Koch, o EPL consegue garantir a interlocução com um público que teria rejeição a essa característica da organização. Tratase de uma escolha estratégica do movimento que depende de uma avaliação dos dirigentes sobre os impactos de sua identidade na interação com o público.

Sobre a natureza do conteúdo exposto pelas páginas à audiência, foi possível evidenciar que as organizações adotam estratégias diferentes de afirmação e coesão identitária, de acordo com o grau de expansão que pretendem. O MBL, que surge com o objetivo de ser uma organização de massas, apresenta baixo grau de demarcação no campo da direita $(1,09 \%)$ quando comparado com as outras duas organizações (EPL 10,20\%; MP 5,13\%) e apresenta sua identidade fundamentalmente pela oposição ao petismo, buscando alcançar o maior público possível dentro desse espectro antipetista - que inclui desde conservadores até insatisfeitos sem posição ideológica clara. 
O Mercado Popular, por outro lado, se identifica como um think tank e tem construído sua interação com o público principalmente por meio de agitação $(22,91 \%)$, de polarização com a esquerda em geral $(21,26 \%)$ e com o petismo $(16,04 \%)$ e de debate público de propostas (15,22\%). O grau de agitação do Mercado Popular se equipara ao do EPL (24,95\%) e do MBL (19,68\%), algo inesperado em princípio, considerando que essa organização não possui pretensão de massificação e tem um processo de seleção fechado.

O EPL, nó central da rede, prioriza publicações que têm como objetivo a agitação $(24,95 \%)$, mobilização $(14,92 \%)$, recrutamento $(14,75 \%)$ e debate público $(12,19 \%)$. Assim, apresenta uma identidade mais marcada pela afirmação do que pela oposição, o que implicaria em formar uma base de participantes com maior unidade ideológica. Além disso, o EPL demonstrou ser a organização que mais busca se diferenciar no campo da direita brasileira, com grau de demarcação em torno de 10,2\%, valor alto se comparado com o MBL $(1,09 \%)$ e ○ $\operatorname{MP}(5,99 \%)$.

Tratam-se de três respostas distintas ao dilema entre coesão e expansão. O MP, ao se referenciar de maneira intensa na crítica à esquerda e realizar mais debate público, coloca-se como um grupo mais dialógico. O EPL constrói-se por meio de intensa autopromoção, com um razoável grau de debate público e de demarcação com a direita, aparentemente buscando se diferenciar como uma alternativa dentro de seu campo político - uma opção mais próxima da noção de coesão e construída a partir da demarcação com outros grupos da direita. $O$ MBL, por outro lado, é mais fortemente identificado pelo antipetismo, com um grau muito reduzido de demarcação, atraindo para si um público mais amplo - o que representa uma tendência maior à expansão.

\section{Agenda futura e limites}

Há diversos elementos a serem aprofundados a partir desta dissertação, como a avaliação da estratégia de comunicação a ser utilizada pelo MBL e outros movimentos antipetistas, a partir da saída do PT do governo, mensurando qual será o impacto das novas estratégias sobre a base militante do movimento e a sua audiência no Facebook. É igualmente relevante compreender qual a 
diferença nos tipos de conteúdo que as organizações direcionam ao seu público interno por meio de mailing, de Whatsapp ou do grupo de Facebook em comparação com o conteúdo que postam para o público em geral nas suas páginas do Facebook.

A construção que os membros dessa Rede farão da recém-criada Tendência Livres no PSL e do possível Partido Novo também se constitui em um potencial objeto de pesquisa, à medida em que entram em uma outra lógica de disputa institucional. Como as organizações se apresentarão em relação a esses partidos e que tipo de vínculos manterão pode representar uma mudança identitária com impacto na maneira com que equacionam o dilema entre coesão e expansão.

Os textos e recursos discursivos ainda podem ser explorados mais afundo com a utilização de outras ferramentas. Uma análise léxica poderia trazer à tona elementos relevantes sobre como essas organizações se apresentam, evidenciando os principais referentes usados nas mensagens das organizações estudadas e a forma com quem constroem seu discurso. Uma análise de conteúdo das postagens, inclusive por meio de ferramentas que identifiquem semelhança e distinções discursivas, pode ser bastante útil à compreensão do perfil das organizações e das narrativas que constroem.

Por fim, à medida em que a apresentação da identidade foi demonstrando-se uma questão central dessa pesquisa, os formulários de pesquisa apresentaram alguns limites. Nesse sentido, um próximo trabalho com o mesmo enfoque, deve contemplar além das questões sobre usos da internet e relações entre organizações, mais elementos referentes à identidade e diálogo com o público.

Além disso, uma análise de perfil das postagens feita com base em dados organizados em séries temporais (mensais ou mesmo trimestrais) poderia avançar na compreensão sobre a existência ou não de alguma tendência de mudança nos usos das redes sociais e na identidade apresentada por essas organizações. 


\section{BIBLIOGRAFIA}

BARDIN, L. Análise de Conteúdo. 4ª. ed. Lisboa: Edições 70, 2009.

BARGH, J. A.; MCKENNA, K. Y. The internet and social life. Annu Rev Psychol, v. 55, p. 573-590, 2004.

BARNETT, C. Neither poison nor cure: Space, scale and public life in media theory. In: COULDRY, N.; MCCARTHY, A. (Eds.). . MediaSpace: Place, Scale and Culture in a Media Age. london: Routledge, 2004. p. 58-74.

BAUMGARTNER, J. C.; MORRIS, J. S. MyFaceTube Politics Social Networking Web Sites and Political Engagement of Young Adults. p. 24-44, 2010.

BENEVENUTO, F. Redes Sociais Online: Técnicas de Coleta, Abordagens de Medição e Desafios Futuros. Tópicos em Sistemas Colaborativos, Interativos, Multimídia, Web e Banco de Dados, p. 41-70, 2010.

BENNETT, W. L.; SEGERBERG, A. the Logic of Connective Action. Information, Communication \& Society, v. 15:5, n. July 2012, p. 739-768, 2012.

BENNETT, W. L.; SEGERBERG, A.; WALKER, S. Organization in the crowd: Peer production in large-scale networked protests. Information, Communication \& Society, v. 17, n. 2, p. 232-260, 2014.

BIMBER, B.; JORBA, L. The Impact of Digital Media on citizenship in a global perspective. Comparing Digital Politics, p. 21-70, 2010.

BLONDEL, V. D. et al. Fast unfolding of communities in large networks. Journal of Statistical Mechanics: Theory and Experiment, v. 10008, n. 10, p. 6, 2008.

$\mathrm{BOB}, \mathrm{C}$. The global right wing and the clash of world politics. [s.l.] Cambridge University Press, 2012.

BOURDIEU, P. Outline of a Theory of Practice. [s.l.] Cambridge University Press, 1977. v. 16

BOYD, D.; CRAWFORD, K. Critical Questions for Big Data. Information, Communication \& Society, v. 15, n. 5, p. 662-679, 2012. 
BRUNS, A.; HIGHFIELD, T.; BURGESS, J. The Arab Spring and Its Social Media Audiences: English and Arabic Twitter Users and Their Networks. Cyberactivism on the Participatory Web, p. 86-116, 2014.

BUCHER, T. Want to be on the top? Algorithmic power and the threat of invisibility on Facebook. New Media \& Society, v. 14, n. 7, p. 1164-1180, 2012.

CALERO VALDEZ, A. et al. Using mixed node publication network graphs for analyzing success in interdisciplinary teams. Lecture Notes in Computer Science (including subseries Lecture Notes in Artificial Intelligence and Lecture Notes in Bioinformatics). Anais...2012

CAROTHERS, T.; YOUNGS, R. The Complexities of Global Protests. Carnegie Endowment for International Peace, 2015.

CASTELLS, M. The Internet Galaxy. [s.I.] Oxford University Press, 2002.

CASTELLS, M. Comunicación y poder. Madrid: Alianza Editorial, 2009.

CLEAVER JR., H. M. The Zapatista Effect: The Internet and the Rise of an Alternative Political Fabric. Journal of International Affairs, v. 51, n. 2, p. $621-$ 640, 1998.

COSTANZA-CHOCK, S. Mapping the repertoire of electronic contention. Representing Resistance: Media, Civil Disobedience and the Global Justice Movement, n. March, p. 350, 2003.

CRANDALL, D. et al. Feedback effects between similarity and social influence in online communities. Proceedings of the ACM SIGKDD International Conference on Knowledge Discovery and Data Mining, p. 160-168, 2008.

DEIBERT, R. J. Black Code Redux: Censorship, Surveillance, and the Militarization of Cyberspace. In: BOLER, M. (Ed.). . Digital Media and Democracy. [s.l: s.n.]. p. Cap.5.

DEIBERT, R. J. The geopolitics of internet control- Censorship, sovereignty, and cyberspace. In: CHADWICK, A.; HOWARD, P. N. (Eds.). . Routledge Handbook of Internet Politics. [s.I.] Routledge International handbooks, 2009. 
DELLA PORTA, D. COMMUNICATION IN MOVEMENT: Information, Communication $\{\&\}$ Society. Information, Communication $\{\&\}$ Society, v. 14, n. 6, p. 800-819, 2011.

DELLA PORTA, D.; MOSCA, L. Global-net for Global Movements? A Network of Networks for a Movement of Movementsin $\ln$ Journal of

Public Policy, v. 25, n. 1, p. 165-190, 2005.

DIANI, M. SOCIAL MOVEMENT NETWORKS VIRTUAL AND REAL. Information, Communication \& Society, v. 3, n. 3, p. 386-401, jan. 2000.

DIMAGGIO, P. et al. Social Implications of the Internet. Annual Review of Sociology, v. 27, n. 1, p. 307-336, 2001.

DOWNING, J. D. H. Computers for Political Change: PeaceNet and Public Data Access. Journal of Communication, v. 39, n. 3, p. 154-162, 1989.

FARRELL, H. The Consequences of the Internet for Politics. Annual Review of Political Science, v. 15, n. 1, p. 35-52, 2012.

FEITELSON, D. G.; FRACHTENBERG, E.; BECK, K. L. Development and deployment at facebook. IEEE Internet Computing, v. 17, n. 4, p. 8-17, 2013.

FRANÇA, M. Lugares de Fala: um conceito para abordar o segmento popular da grande imprensa. Contracampo, n. 12, p. 103-114, 2005.

FROEHLING, O. The Cyberspace "War of Ink and Internet" in Chiapas, Mexico. Geographical Review, v. 87, n. 2, p. 291-307, 1997.

GALACZ, A.; SMAHEL, D. Information Society from a Comparative Perspective : Digital Divide and Social Effects of the Internet Republic of Singapore Methodology : Data samples The data analyzed in this paper was collected and is owned by the following institutes: Journal of Psychosocial Research on Cyberspace, v. 2007072401, p. 1-10, 2008.

GARCÍA, C. et al. What can Twitter tell us about social movements' network topology and centrality? Analysing the case of the 2011 - 2013 Chilean student movement. Inst. J. Organisational Design and Engineering, v. 3, n. 3/4, p. 
317-337, 2014.

GARRET, R. K. Protest in an Information Society: a review of literature on social movements and new ICTs. Information, Communication \& Society, v. 9, n. 2, p. 202-224, abr. 2006.

GERBAUDO, P. Introduction. Tweets and the Streets: Social Media and Contemporary Activism, p. 1-17, 2012.

GERBAUDO, P. The persistence of collectivity in digital protest. Information, Communication \& Society, v. 17, n. 2, p. 264-268, 2014.

GERBAUDO, P.; TRERÉ, E. In search of the "we" of social media activism: introduction to the special issue on social media and protest identities. Information, Communication \& Society, v. 18, n. 8, p. 865-871, 2015.

GIL DE ZUNIGA, H. Citizenship, Social Media, and Big Data: Current and Future Research in the Social Sciences. Social Science Computer Review, p. 1-7, 2015.

HARGITTAI, E. Second-Level Digital Divide : Mapping Differences in. [s.I: S.n.].

HOWARD, P. N. New media Campaigns and the Managed Citzen. Cambridge: Cambridge University Press, 2005.

ILTEN, C. "Use Your Skills to Solve This Challenge!": The Platform Affordances and Politics of Digital Microvolunteering. Social Media + Society, v. 1, n. 2, 2015.

LATOUR, B. Tarde's idea of quantification. The Social After Gabriel Tarde: Debates and Assessments, p. 145-162, 2010.

LAZER, D. et al. The Parable of Google Flu: Traps in Big Data Analysis. Science, v. 343, n. 6167, p. 1203-1205, 2014.

MADEIRA, R.; TAROUCO, G. A “ direita envergonhada " no Brasil : como partidos reinterpretam seus vínculos com o regime militar ? Buenos Aires: [s.n.]. Disponível em: <http://www.aacademica.org/000-036/804>. 
MEGAN BOLER. Digital Media and Democracy. Cambridge, Massachusetts: The MIT Press, 2008.

MELUCCI, A. Nomads of the PresentPhiladelphiaTemple University Press, , 1989.

MELUCCI, A. Challenging codes: Collective action in the information age. [s.l.] Cambridge University Press, 1996.

MERCEA, D. PROBING THE IMPLICATIONS OF FACEBOOK USE FOR THE ORGANIZATIONAL FORM OF SOCIAL MOVEMENT ORGANIZATIONS. Information, Communication \& Society, v. 16, n. 8, p. 1306-1327, out. 2013.

METAXAS, P. T.; MUSTAFARAJ, E. Social Media and the Elections. Science, v. 338, n. 6106, p. 472-473, 2012.

METAXAS, P. T.; MUSTAFARAJ, E.; GAYO-AVELLO, D. How (Not) to predict elections. Proceedings - 2011 IEEE International Conference on Privacy, Security, Risk and Trust and IEEE International Conference on Social Computing, PASSAT/SocialCom 2011, p. 165-171, 2011.

MOROZOV, E. The net delusion: The dark side of Internet freedom. New York: Public Affairs, 2011.

MORRIS, D. S.; MORRIS, J. S. Digital inequality and participation in the political process: Real or imagined? Social Science Computer Review, v. 31, n. 5, p. 589-600, 2013.

MURRU, M. F. New media - new public spheres? An analysis of online shared spaces becoming public agoras. In: CARPENTIER, N.; PRUULMANNVENGERFELD, P. (Eds.). . Communicative Approaches to Politics and Ethics in Europe. [s.I.] Tartu University Press, 2009. p. 141-154.

NICKERSON, R. S. Confirmation bias: A ubiquitous phenomenon in many guises. Review of General Psychology, v. 2, n. 2, p. 175-220, 1998.

NIELSEN, M. Reinventing Discovery: The New Age of Networked Science. [s.l: s.n.]. 
NIELSEN, R. K. Mundane internet tools, mobilizing practices, and the coproduction of citizenship in political campaigns. New Media \& Society, v. 13, n. 5, p. $755-771,2011 b$.

NORRIS, P. Digital Divide: Civic Engagement, Information Poverty, and the Internet WorldwideCommunication society and politics, 2001. Disponível em: $\quad$ <http://www.amazon.com/Digital-Divide-Engagement-InformationCommunication/dp/0521002230ไnhttp://ssc.sagepub.com/cgi/doi/10.1177/08944 39302238974>

OLORUNNISOLA, A. A.; MARTIN, B. L. Influences of media on social movements: Problematizing hyperbolic inferences about impacts. Telematics and Informatics, v. 30, n. 3, p. 275-288, 2013.

PHILLIPS, D. J. Locational surveillance Embracing the patterns of our lives. In: HOWARD, P. N.; CHADWICK, A. (Eds.). . Routledge Handbook of Internet Politics. [s.I.] Routledge International handbooks, 2009.

POLLETTA, F.; JASPER, J. M. Collective identity and social movements. Annual Review of Sociology, n. 27, p. 283-305, 2001.

RAINIE, L.; WELLMAN, B. The battle of freedom and control in a networked world . New scientist, v. 2012, n. 25 Jan, 2012.

RECUERO, R. Contribuições da Análise de Redes Sociais para o Estudo das Redes Sociais na Internet: $O$ caso da hashtag \#Tamojuntodilma e \#CalaabocaDilma. Revista Fronteiras (Online), v. 16, n. 1, p. 22, 2014.

REGATTIERI, L. L. et al. MarcoCivil: Visualizing the Civil rights Framework for the Internet in Brazil. CEUR Workshop Proceedings, v. 1210, 2014.

RIEDER, B. Studying Facebook via Data Extraction: The Netvizz Application. Proceedings of WebSci '13, the 5th Annual ACM Web Science Conference, p. 346-355, 2013.

RONFELDT, D. et al. The Zapatista Social Netwar in Mexico. [s.I: s.n.]. SKOCPOL, T.; HERTEL-FERNANDEZ, A. THE KOCH EFFECT The Impact of a 
Cadre-Led Network on American Politics and Alexander Hertel-Fernandez Prepared for presentation at the Inequality Mini-Conference, Southern Political Science Association San Juan , Puerto Rico , January 8 , 2016. 2016.

STUDENTS FOR LIBERTY. 2008-2009 Annual Report. Washington D.C.: [s.n.]. Disponível em: <http://studentsforliberty.org/wp-content/uploads/2010/07/20082009-SFL-Annual-Report.pdf>.

STUDENTS FOR LIBERTY. Students For Liberty Report - Quarterly Fall 2015. [s.l: s.n.].

STUDENTS FOR LIBERTY. Annual report 2014-2015. [s.l: s.n.]. Disponível em: $<$ https://issuu.com/studentsforliberty/docs/sfl-annual-report-2015-web>.

TARROW, S. O Poder em Movimento. Petrópolis: Vozes, 2009.

TARROW, S. Critical Dialogue. The Logic of Connective Action: Digital Media and the Personalization of Contentious Politics. By Bennett W. Lance and Segerberg Alexandra. New York: Cambridge University Press, 2013. 251p. $\$ 85.00$ cloth, $\$ 29.99$ paper. Perspectives on Politics, v. 12 , n. 02 , p. 468-470, 2014.

TARROW, S.; TILLY, C.; MCADAM, D. Para mapear o confronto político. Lua Nova, n. 76, p. 11-48, 2009.

TATAGIBA, L.; TRINDADE, T.; TEIXEIRA, A. C. C. "CorruPTos" Um ensaio sobre protestos à direita no Brasil (2007-2015). no prelo: [s.n.].

THEOCHARIS, Y. et al. Twitter to Mobilise Protest Action: Transnational Online Mobilisation Patterns and Action Repertoires in the Occupy Wall Street, Indignados and Aganaktismenoi. DI.Conjugateprior.Org, n. March, p. 11-16, 2013.

TOLLE, K. M.; TANSLEY, D. S. W.; HEY, A. J. G. The fourth Paradigm: Dataintensive scientific discovery. Proceedings of the IEEE. Anais...2011

TRETJAK, K. Opportunity and Danger: Why Studies of the Right are Crucial for U.S. Anthropology and Beyond. North American Dialogue, v. 16, n. 2, p. $60-$ 
68, 2013.

VALENZUELA, S. Unpacking the Use of Social Media for Protest Behavior: The Roles of Information, Opinion Expression, and Activism. American Behavioral Scientist, v. 57, n. 7, p. 920-942, 2013.

VALENZUELA, S.; ARRIAGADA, A.; SCHERMAN, A. A trend study of social media and protest behavior: Facebook, Twitter and youth mobilization in Chile (2009-2012). 2013.

VAN LAER, J.; VAN AELST, P. INTERNET AND SOCIAL MOVEMENT ACTION REPERTOIRES. Information, Communication \& Society, v. 13, n. 8, p. 11461171, dez. 2010.

VISSERS, S.; STOLLE, D. The Internet and new modes of political participation: online versus offline participation. Information, Communication \& Society, v. 17, n. 8, p. 937-955, 2014.

VON BÜLOW, M. The Survival of Leaders and Organizations in the Digital Age : Lessons from the Chilean Student Movement. no prelo: [s.n.].

WELLMAN, B. et al. Does the Internet Increase, Decrease, or Supplement Social Capital?: Social Networks, Participation, and Community Commitment. American Behavioral Scientist, v. 45, n. 3, p. 436-455, 2001.

WELLMAN, B.; HAYTHORNTHWAITE, C. The Internet in Everyday Life. [s.I.] Blackwell Publishing, 2002.

WOJCIESZAK, M. E.; MUTZ, D. C. Online groups and political discourse: Do online discussion spaces facilitate exposure to political disagreement? Journal of Communication, v. 59, n. 1, p. 40-56, 2009.

ZHU, Q. Citizen-Driven International Networks and Globalization of Social Movements on Twitter. Social Science Computer Review, p. 0894439315617263-, 2015. 


\section{Questionário para entrevistas semiestruturadas com líderes do Estudantes Pela Liberdade}

Nome:

Universidade:

Idade:

Período em que participou do EPL:

Local e data da entrevista:

1. Em que momento você entrou na sua organização?

( )Fundação ( )outro:

2. Qual foi o principal motivo para a fundação do Estudantes Pela Liberdade e qual o objetivo da organização?

\section{Fundação (exclusivo para fundadores)}

3. Quais atores tiveram participação fundamental na fundação do Estudantes Pela Liberdade?

4. Qual foi o papel da Internet nesse momento de fundação do Estudantes pela Liberdade?

\section{Funcionamento da organização}

5. Com que intensidade vocês utilizam ferramentas digitais como plataforma de reunião?

6. Com que intensidade vocês utilizam ferramentas digitais como fórum para formulação política?

7. Com que intensidade vocês utilizam ferramentas digitais como mecanismo para mobilização e recrutamento de membros?

8. O EPL realiza reuniões virtuais?

Caso sim, tratavam-se de: (marcar mais de uma opção, caso se aplique)

[ ]reuniões de direção

[ ]reunião com membros ou apoiadores 
[ ]reuniões abertas ao público

Com que frequência se realizam essas reuniões?

9. Quais Tipos de atividades abertas ao público, além das manifestações, vocês realizam?

\section{Uso da Internet}

10. Estou interessado em saber de que maneira e com quais objetivos a sua organização utiliza a internet.

\begin{tabular}{|l|l|l|l|l|l|}
\hline Plataforma & $\begin{array}{c}\text { Mobilização } \\
\text { para atividades } \\
\text { públicas }\end{array}$ & $\begin{array}{l}\text { Debate } \\
\text { público }\end{array}$ & $\begin{array}{l}\text { Debate } \\
\text { interno }\end{array}$ & $\begin{array}{l}\text { Deliberação } \\
\text { política }\end{array}$ & $\begin{array}{l}\text { Recrutamento de } \\
\text { novos } \\
\text { participantes }\end{array}$ \\
\hline $\begin{array}{l}\text { Lista de } \\
\text { emails }\end{array}$ & & & & & \\
\hline Twitter & & & & & \\
\hline $\begin{array}{l}\text { Grupo do } \\
\text { Facebook }\end{array}$ & & & & & \\
\hline $\begin{array}{l}\text { Página do } \\
\text { Facebook }\end{array}$ & & & & & \\
\hline Whatsapp & & & & & \\
\hline Blogue & & & & & \\
\hline Página & & & & & \\
\hline Youtube & & & & & \\
\hline $\begin{array}{l}\text { Outros: } \\
\text { Google drive } \\
\text { Google } \\
\text { Hangout }\end{array}$ & & & & & \\
\hline
\end{tabular}

11. Também nos interessa saber se mudou a importância de cada uma das plataformas citadas desde que o EPL começou a utilizá-las. Em caso positivo, poderia descrever essas mudanças?

12. Na sua opinião qual a importância da internet para o trabalho de mobilização e recrutamento da sua organização?

\section{Eficácia e limites no uso da internet}

13. Em relação à mídia tradicional (jornais, rádio e televisão), o quão importante são as redes sociais como um canal de divulgação de informações e ideias?

14. Também queremos saber se, em sua opinião, há impactos negativos, ou desafios a serem enfrentados pelo movimento estudantil no uso de plataformas virtuais como Facebook, Blogues, whatsapp. Se sim, poderia exemplificar? 
15. Que mudanças você acredita que os novos movimentos precisam fazer para um melhor uso da internet?

\title{
V. Relações Internacionais
}

16. As redes sociais foram usados intensamente para estabelecer relações com os atores em outros países, por exemplo na "Primavera Árabe", nos protestos na Turquia e no movimento Occupy. Para o trabalho da sua organização, você acredita que a internet desempenha esse mesmo papel? Porque sim / não ?

17. Vocês se comunicam com potenciais aliados em outros países? Se sim, quais plataformas utilizam mais (lista de emails, grupo de Facebook, blogs, whatsapp)?

18. Quais foram os principais objetivos do contato com atores/organizações de outros países?

\section{Relações interorganizacionais}

19. Como você descreveria a relação da sua organização com:

\author{
Instituto Liberal \\ (marcar alternativamente) \\ () somos organizações politicamente rivais \\ () somos organizações com forte dissenso \\ ( ) não temos relações de qualquer natureza \\ () temos proximidade ideológica \\ () somos organizações aliadas \\ [marcar mais de uma opção, caso se aplique] \\ [ ] alguns de nossos membros vieram desta organização ou foram para ela \\ [ ] alguns de nossos membros participam de ambas organizações \\ [] formulamos e debatemos política conjuntamente \\ [ ] ambas organizações estão em pelo menos um mesmo fórum ou rede de \\ organizações
}

Instituto Ordem Livre

(marcar alternativamente)

() somos organizações politicamente rivais

() somos organizações com forte dissenso

( ) não temos relações de qualquer natureza

() temos proximidade ideológica

( ) somos organizações aliadas

[marcar mais de uma opção, caso se aplique]

[ ] alguns de nossos membros vieram desta organização ou foram para ela

[ ] alguns de nossos membros participam de ambas organizações

[ ] formulamos e debatemos política conjuntamente 
[ ] ambas organizações estão em pelo menos um mesmo fórum ou rede de organizações

Movimento Brasil Livre

(marcar alternativamente)

() somos organizações politicamente rivais

() somos organizações com forte dissenso

( ) não temos relações de qualquer natureza

() temos proximidade ideológica

() somos organizações aliadas

[marcar mais de uma opção, caso se aplique]

[ ] alguns de nossos membros vieram desta organização ou foram para ela

[ ] alguns de nossos membros participam de ambas organizações

[ ] formulamos e debatemos política conjuntamente

[ ] ambas organizações estão em pelo menos um mesmo fórum ou rede de organizações

\section{Mercado Popular}

(marcar alternativamente)

() somos organizações politicamente rivais

() somos organizações com forte dissenso

() não temos relações de qualquer natureza

( ) temos proximidade ideológica

( ) somos organizações aliadas

[marcar mais de uma opção, caso se aplique]

[ ] alguns de nossos membros vieram desta organização ou foram para ela

[ ] alguns de nossos membros participam de ambas organizações

[ ] formulamos e debatemos política conjuntamente

[ ] ambas organizações estão em pelo menos um mesmo fórum ou rede de organizações

20. Há algum parceiro da sua organização que destacaria como fundamental? Se sim, quem e porque?

Ao finalizar a entrevista, pedir indicação de outros atores a entrevistar e fontes documentais públicas. 


\section{ANEXO II}

\section{Questionário para entrevistas semiestruturadas com líderes do Movimento Brasil Livre}

Nome:

Universidade:

Idade:

Período em que participou do Movimento

Local e data da entrevista:

1. Em que momento você entrou no MBL?

( )Fundação ( )outro:

2. Qual foi o principal motivo para a fundação do Movimento Brasil Livre e qual o objetivo da Organização?

\section{Fundação (exclusivo para fundadores)}

3. Quais atores tiveram participação fundamental na fundação do Movimento Brasil Livre?

4. Qual foi o papel da Internet nesse momento de fundação do Movimento Brasil Livre?

\section{Funcionamento da organização}

5. Com que intensidade vocês utilizam ferramentas digitais como plataforma de reunião?

6. Com que intensidade vocês utilizam ferramentas digitais como fórum para formulação política?

7. Com que intensidade vocês utilizam ferramentas digitais como mecanismo para mobilização e recrutamento de membros?

8. $\mathrm{OMBL}$ realiza reuniões virtuais?

Caso sim, tratavam-se de: (marcar mais de uma opção, caso se aplique)

[ ] ]reuniões de direção

[ ] ]reunião com membros ou apoiadores

[ ]reuniões abertas ao público

Com que frequência se realizam essas reuniões? 
9. Quais Tipos de atividades abertas ao público, além das manifestações, vocês realizam?

\section{Uso da Internet}

10. Estou interessado em saber de que maneira e com quais objetivos a sua organização utiliza a internet.

\begin{tabular}{|c|c|c|c|c|c|}
\hline Plataforma & $\begin{array}{c}\text { Mobilização } \\
\text { para atividades } \\
\text { públicas }\end{array}$ & $\begin{array}{l}\text { Debate } \\
\text { público }\end{array}$ & $\begin{array}{l}\text { Debate } \\
\text { interno }\end{array}$ & $\begin{array}{l}\text { Deliberação } \\
\text { política }\end{array}$ & $\begin{array}{l}\text { Recrutamento de } \\
\text { novos } \\
\text { participantes }\end{array}$ \\
\hline $\begin{array}{l}\text { Lista de e- } \\
\text { mails }\end{array}$ & & & & & \\
\hline Twitter & & & & & \\
\hline $\begin{array}{l}\text { Grupo do } \\
\text { Facebook }\end{array}$ & & & & & \\
\hline $\begin{array}{l}\text { Página do } \\
\text { Facebook }\end{array}$ & & & & & \\
\hline Whatsapp & & & & & \\
\hline Blogue & & & & & \\
\hline Página & & & & & \\
\hline Youtube & & & & & \\
\hline Outros: & & & & & \\
\hline
\end{tabular}

11. Também nos interessa saber se mudou a importância de cada uma das plataformas citadas desde que o Movimento começou a utilizá-las. Em caso positivo, poderia descrever essas mudanças?

12. Na sua opinião qual a importância da internet para o trabalho de mobilização e recrutamento da sua organização?

\section{Eficácia e limites no uso da internet}

13. Em relação à mídia tradicional (jornais, rádio e televisão), o quão importante são as redes sociais para a estratégia de vocês?

14. Também queremos saber se, em sua opinião, há impactos negativos, ou desafios a serem enfrentados pelo movimento estudantil no uso de plataformas virtuais como Facebook, Blogues, whatsapp. Se sim, poderia exemplificar?

15. Que mudanças você acredita que o movimento estudantil precisa fazer para um melhor uso da internet?

\section{Relações Internacionais}


16. As redes sociais foram usados intensamente para estabelecer relações com os atores em outros países , por exemplo na "Primavera Árabe", nos protestos na Turquia e no movimento Occupy. Para o trabalho da sua organização, você acredita que a internet desempenha esse mesmo papel? Porque sim / não ?

17. Vocês se comunicam com potenciais aliados em outros países? Se sim, quais plataformas utilizam mais (lista de emails, grupo de Facebook, blogs, whatsapp)?

18. Quais foram os principais objetivos do contato com atores/organizações de outros países?

\section{Relações interorganizacionais}

19. Como você descreveria a relação da sua organização com:

Estudantes pela Liberdade

(marcar alternativamente)

() somos organizações politicamente rivais

() somos organizações com forte dissenso

( ) não temos relações de qualquer natureza

() temos proximidade ideológica

() somos organizações aliadas

[marcar mais de uma opção, caso se aplique]

[ ] alguns de nossos membros vieram desta organização ou foram para ela

[ ] alguns de nossos membros participam de ambas organizações

[ ] formulamos e debatemos política conjuntamente

[ ] ambas organizações estão em pelo menos um mesmo fórum ou rede de organizações

Instituto Liberal

(marcar alternativamente)

( ) somos organizações politicamente rivais

( ) somos organizações com forte dissenso

( ) não temos relações de qualquer natureza

() temos proximidade ideológica

( ) somos organizações aliadas

[marcar mais de uma opção, caso se aplique]

[ ] alguns de nossos membros vieram desta organização ou foram para ela

[ ] alguns de nossos membros participam de ambas organizações

[ ] formulamos e debatemos política conjuntamente

[ ] ambas organizações estão em pelo menos um mesmo fórum ou rede de organizações

Instituto Ordem Livre

(marcar alternativamente)

() somos organizações politicamente rivais

() somos organizações com forte dissenso

( ) não temos relações de qualquer natureza

( ) temos proximidade ideológica

() somos organizações aliadas 
[marcar mais de uma opção, caso se aplique]

[ ] alguns de nossos membros vieram desta organização ou foram para ela

[ ] alguns de nossos membros participam de ambas organizações

[ ] formulamos e debatemos política conjuntamente

[ ] ambas organizações estão em pelo menos um mesmo fórum ou rede de organizações

20. Há algum parceiro da sua organização que destacaria como fundamental? Se sim, quem e porque?

Ao finalizar a entrevista, pedir indicação de outros atores a entrevistar e fontes documentais públicas. 


\section{ANEXO III}

\section{Questionário para entrevistas semiestruturadas com}

\section{líderes do Instituto Mercado Popular}

Nome:

Universidade:

Idade:

Período em que participou do Instituto:

Data da entrevista:

1. Em que momento você entrou no Mercado Popular?

( )Fundação ( )outro:

2. Qual foi o principal motivo para a fundação do Mercado Popular e qual resultado vocês esperavam alcançar com a criação da página?

\section{Fundação (exclusivo para fundadores)}

3. Quais atores tiveram participação fundamental na fundação do Mercado Popular?

4. Qual é a relação de vocês com o Grupo Estudantes Pela Liberdade?

\section{Funcionamento da organização}

5. Vocês utilizam ferramentas digitais (lista de e-mails, facebook, Skype, fórum virtual) como plataforma de debate?

6. Com que intensidade vocês utilizavam ferramentas digitais como mecanismo para mobilização e recrutamento de membros?

7. O Mercado Popular realiza reuniões virtuais?

Caso sim, tratam-se de: (marcar mais de uma opção, caso se aplique)

[ ]reuniões de direção

[ ]reunião com colaboradores ou apoiadores

[ ]reuniões abertas ao público

Com que frequência se realizam essas reuniões?

8. Quais Tipos de atividades abertas ao público vocês realizam virtual e presencialmente? 


\section{Uso da Internet}

9. Estou interessado em saber de que maneira e com quais objetivos a sua organização utiliza a internet.

\begin{tabular}{|l|l|l|l|l|l|}
\hline Plataforma & $\begin{array}{c}\text { Mobilização } \\
\text { para atividades } \\
\text { públicas }\end{array}$ & $\begin{array}{l}\text { Debate } \\
\text { público }\end{array}$ & $\begin{array}{l}\text { Debate } \\
\text { interno }\end{array}$ & $\begin{array}{l}\text { Deliberação } \\
\text { política }\end{array}$ & $\begin{array}{l}\text { Recrutamento de } \\
\text { novos } \\
\text { participantes }\end{array}$ \\
\hline $\begin{array}{l}\text { Lista de e- } \\
\text { mails }\end{array}$ & & & & & \\
\hline Twitter & & & & & \\
\hline $\begin{array}{l}\text { Grupo do } \\
\text { Facebook }\end{array}$ & & & & & \\
\hline $\begin{array}{l}\text { Página do } \\
\text { Facebook }\end{array}$ & & & & & \\
\hline Whatsapp & & & & & \\
\hline Blogue & & & & & \\
\hline Youtube & & & & & \\
\hline Outros: & & & & & \\
\hline
\end{tabular}

10. Também nos interessa saber se mudou a importância de cada uma das plataformas citadas desde a fundação da Página. Em caso positivo, poderia descrever essas mudanças?

11. Na sua opinião qual a importância da internet para o trabalho de mobilização e recrutamento do Mercado Popular?

\section{Eficácia e limites no uso da internet}

12. Em relação à mídia tradicional (jornais, rádio e televisão), o quão importante são as redes sociais como um canal de divulgação de informações e ideias?

13. Também queremos saber se, em sua opinião, há impactos negativos, ou desafios a serem enfrentados pelos movimentos de juventude no uso de plataformas virtuais como Facebook, Blogues, whatsapp. Se sim, poderia exemplificar?

14. Que mudanças você acredita que os movimentos e organizações políticas precisam fazer para um melhor uso da internet?

\section{Relações Internacionais}


15. As redes sociais foram usadas intensamente para estabelecer relações com os atores em outros países , por exemplo na "Primavera Árabe", nos protestos na Turquia e no movimento Occupy. Para o trabalho da sua organização, você acredita que a internet desempenha esse mesmo papel? Porque sim / não ?

16. Vocês se comunicam com potenciais aliados em outros países? Se sim, quais plataformas utilizam mais (lista de emails, grupo de Facebook, blogs, whatsapp)?

17. Quais são os principais objetivos no contato com atores/organizações de outros países?

XVIII. Relações interorganizacionais

18. Como você descreveria a relação da sua organização com:

Estudantes pela Liberdade

(marcar alternativamente)

() somos organizações politicamente rivais

() somos organizações com forte dissenso

( ) não temos relações de qualquer natureza

() temos proximidade ideológica

( ) somos organizações aliadas

[marcar mais de uma opção, caso se aplique]

[ ] alguns de nossos membros vieram desta organização ou foram para ela

[ ] alguns de nossos membros participam de ambas organizações

[ ] formulamos e debatemos política conjuntamente

[ ] ambas organizações estão em pelo menos um mesmo fórum ou rede de organizações

Movimento Brasil Livre

(marcar alternativamente)

( ) somos organizações politicamente rivais

() somos organizações com forte dissenso

( ) não temos relações de qualquer natureza

() temos proximidade ideológica

( ) somos organizações aliadas

[marcar mais de uma opção, caso se aplique]

[ ] alguns de nossos membros vieram desta organização ou foram para ela

[ ] alguns de nossos membros participam de ambas organizações

[ ] formulamos e debatemos política conjuntamente

[ ] ambas organizações estão em pelo menos um mesmo fórum ou rede de organizações

Instituto Liberal

(marcar alternativamente)

() somos organizações politicamente rivais

() somos organizações com forte dissenso

( ) não temos relações de qualquer natureza

( ) temos proximidade ideológica 
( ) somos organizações aliadas

[marcar mais de uma opção, caso se aplique]

[ ] alguns de nossos membros vieram desta organização ou foram para ela

[ ] alguns de nossos membros participam de ambas organizações

[ ] formulamos e debatemos política conjuntamente

[ ] ambas organizações estão em pelo menos um mesmo fórum ou rede de organizações

Instituto Ordem Livre

(marcar alternativamente)

() somos organizações politicamente rivais

() somos organizações com forte dissenso

( ) não temos relações de qualquer natureza

( ) temos proximidade ideológica

( ) somos organizações aliadas

[marcar mais de uma opção, caso se aplique]

[ ] alguns de nossos membros vieram desta organização ou foram para ela

[ ] alguns de nossos membros participam de ambas organizações

[ ] formulamos e debatemos política conjuntamente

[ ] ambas organizações estão em pelo menos um mesmo fórum ou rede de organizações

19. Há algum parceiro da sua organização que destacaria como fundamental? Se sim, quem e porque?

Ao finalizar a entrevista, pedir indicação de outros atores a entrevistar e fontes documentais públicas 


\section{ANEXO IV}

Procedimento para extração de dados do Facebook e importação para o NVIVO

1. Entre em sua conta do Facebook, procure o aplicativo Netvizz na barra de pesquisa e abra-o.

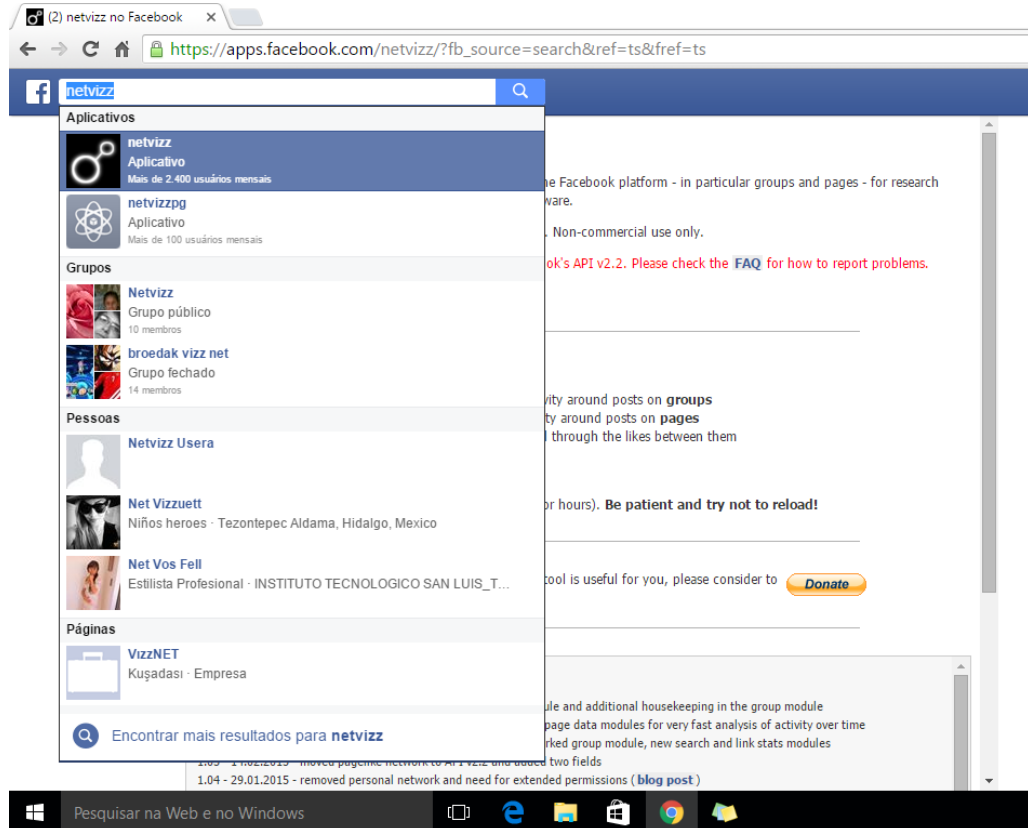

* Pesquisar na Web e no Windows $\quad$ प

2. Em seguida, clique na opção "page data"

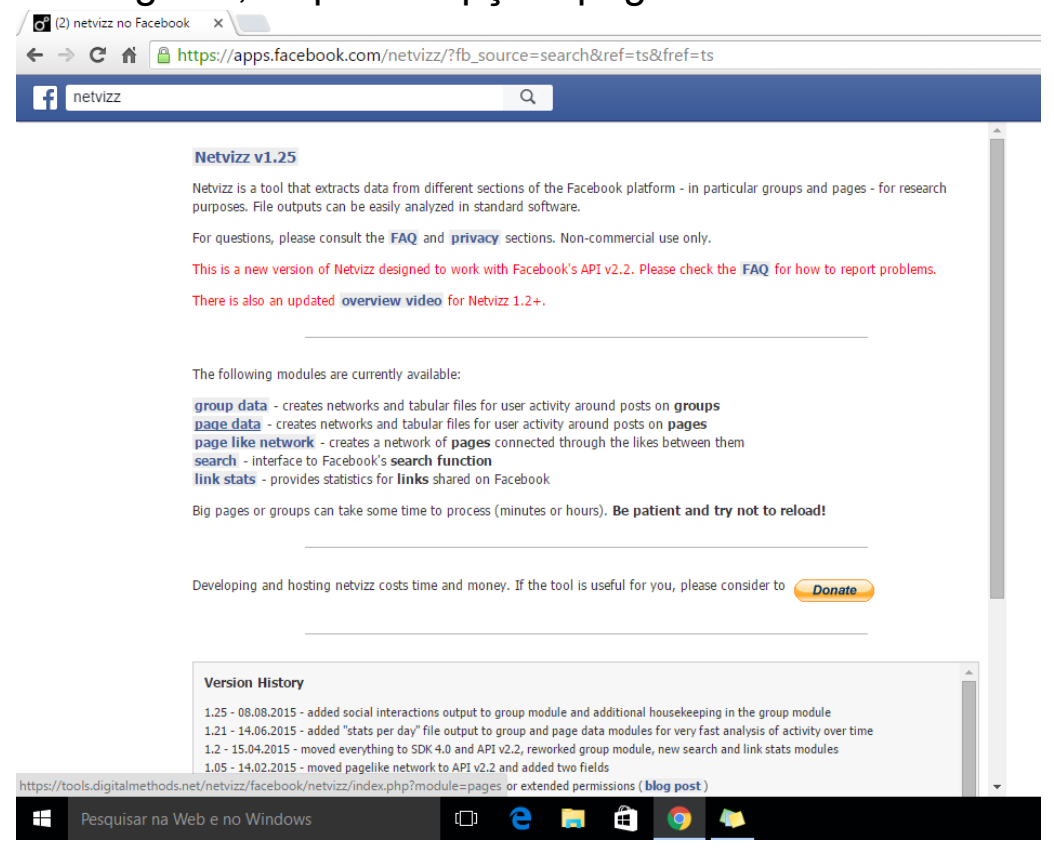


3. Escolha o número de posts ou o período temporal do qual deseja fazer a extração. Caso queria apenas fazer a extração dos posts sem comentários e outros dados, marque a caixa de diálogo get posts statistics only. Em seguida, você precisara obter o número de identificação da página. Clique no link indicado.

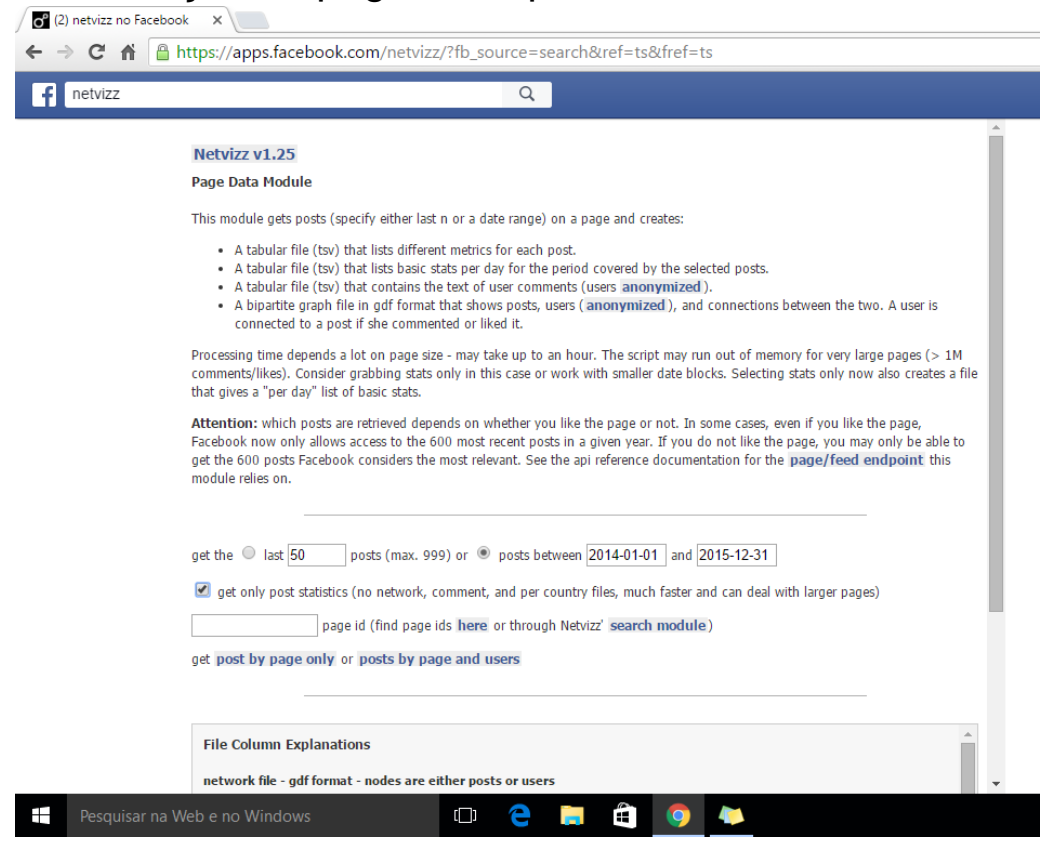

4. Acesse a nova janela e cole o endereço da página cujo número de identificação deseja saber na caixa correspondente e clique em Lookup. Em seguida, copie e número fornecido. 
Looking for your Facebook profile ID / Group ID / Page ID

\section{Type your Facebook profile URL}

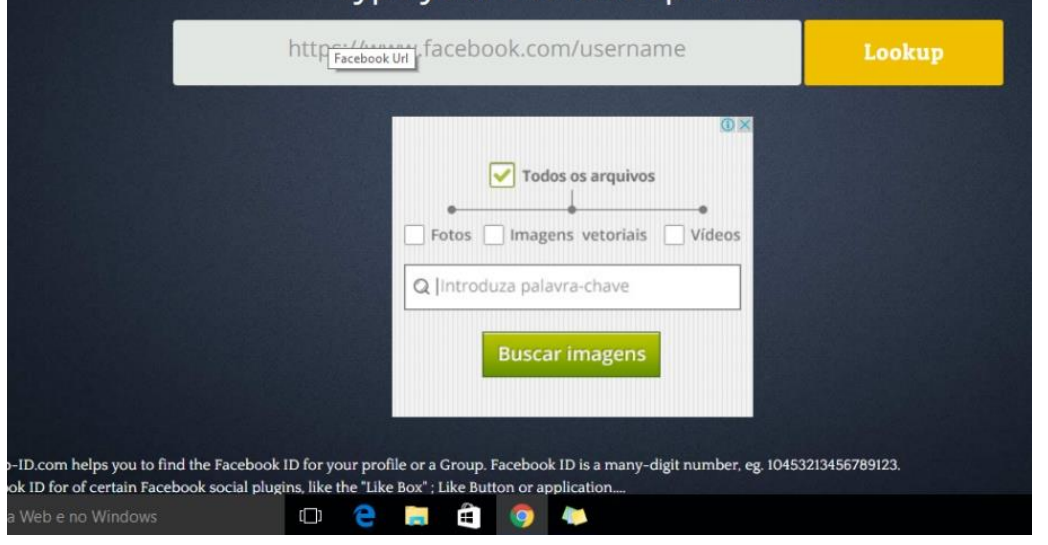

sook $x$ Find my Facebook ID | Fin $x$

inttps://lookup-id.com

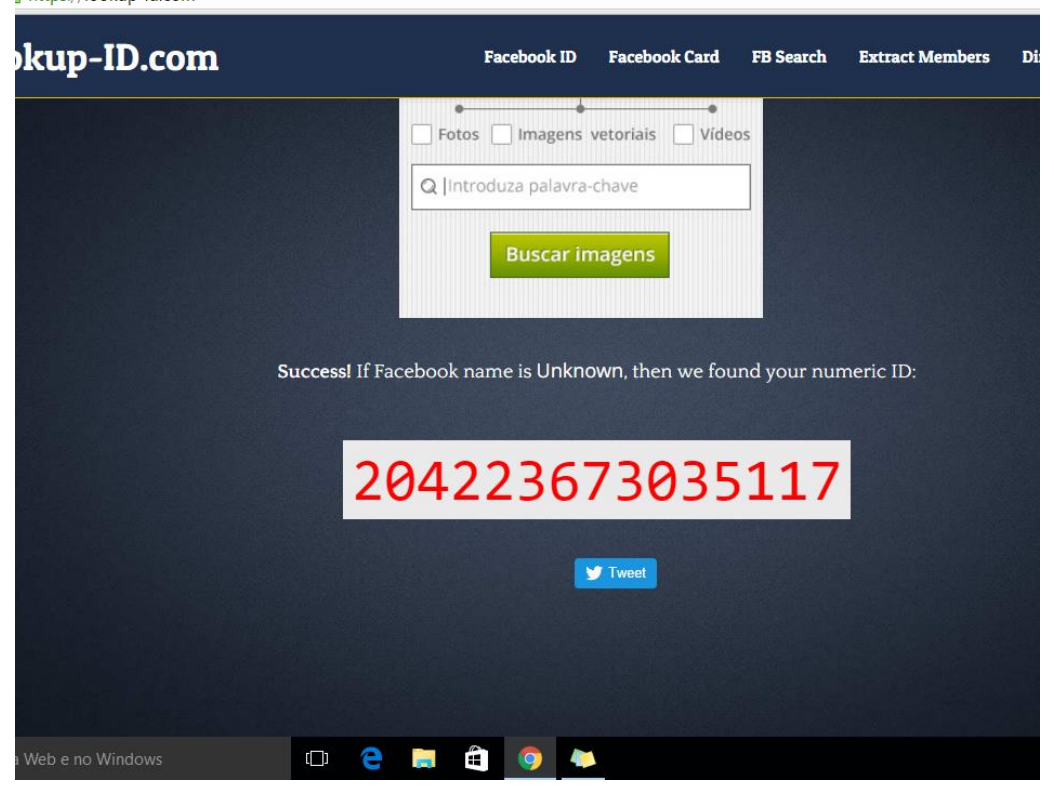

5. Cole o id da página no capo correspondente e escolha a opção desejada: apenas posts da página ou posts da página e de usuários. Aguarde a mineração dos dados. 


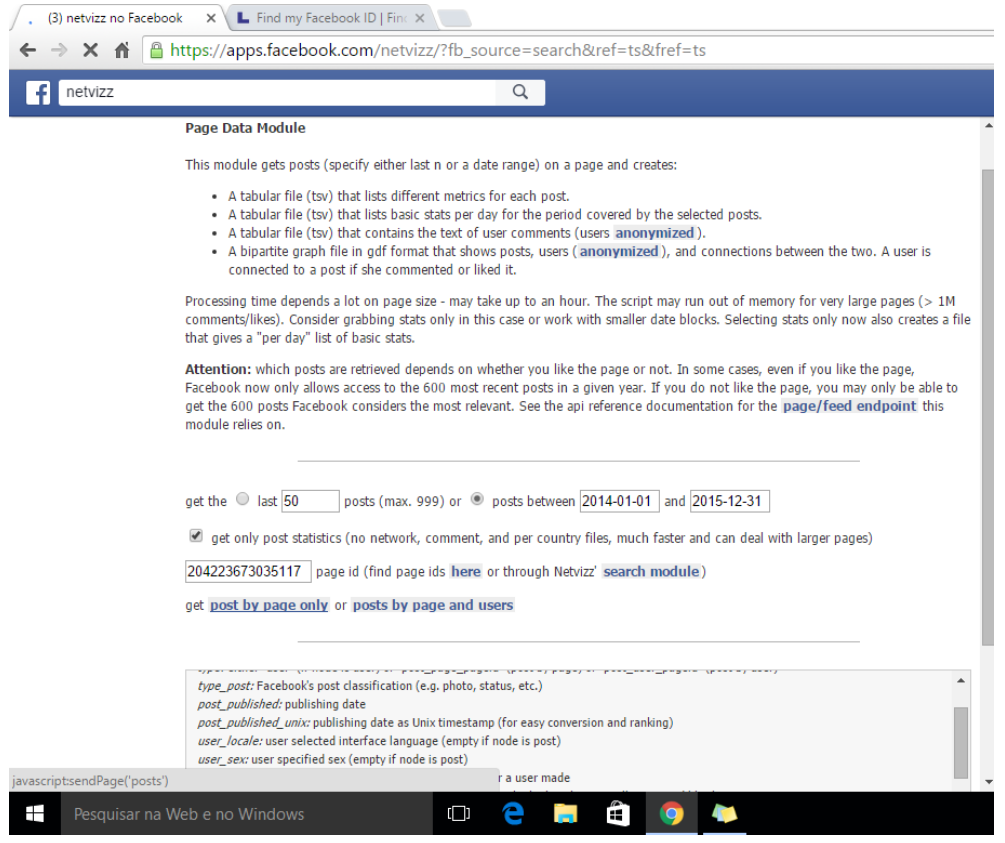

6. Faça o download do arquivo clicando em "zip archive" e descompacte os arquivos no local de preferência. 


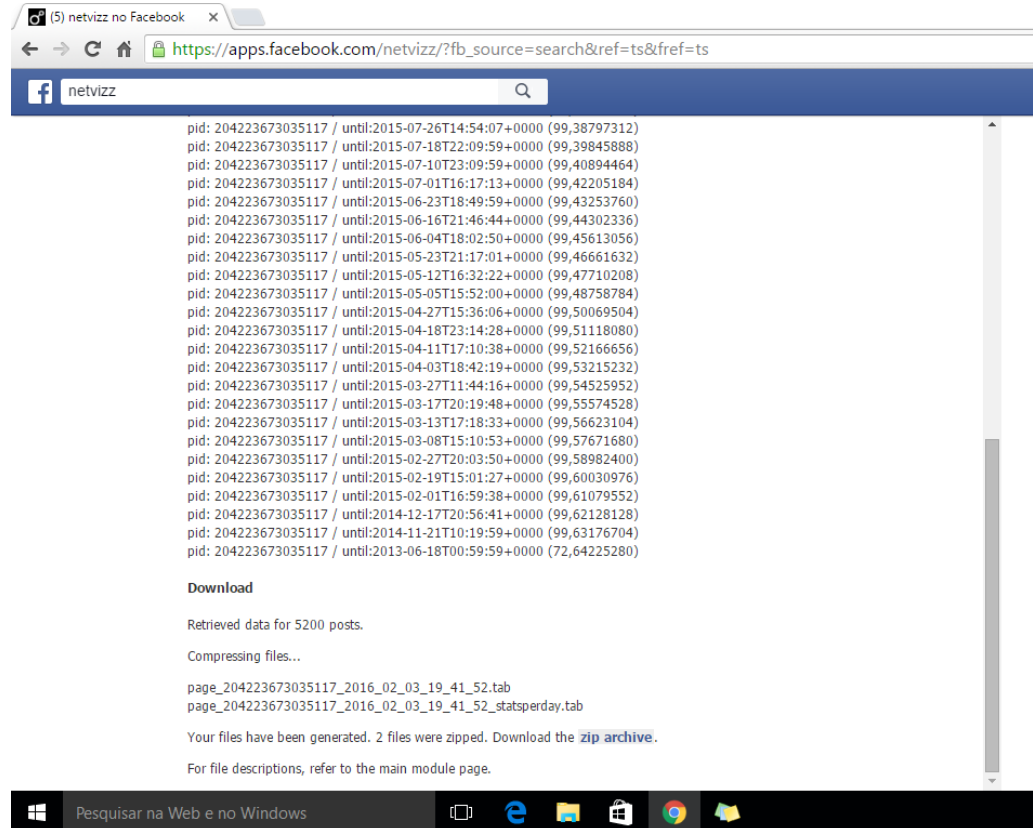

7. Em seguida, abra o Excel e selecione a opção "Dados" > "Obter dados externos" > "De Texto". Selecione a opção "Todos os arquivos (*..")" no filtro de pesquisa, busque o arquivo desejado e clique em abrir. Obs.: $\mathrm{O}$ arquivo maior contém o conteudo das postagens e as estastíticas, enquanto o menor refere-se apenas às estastístitcas.

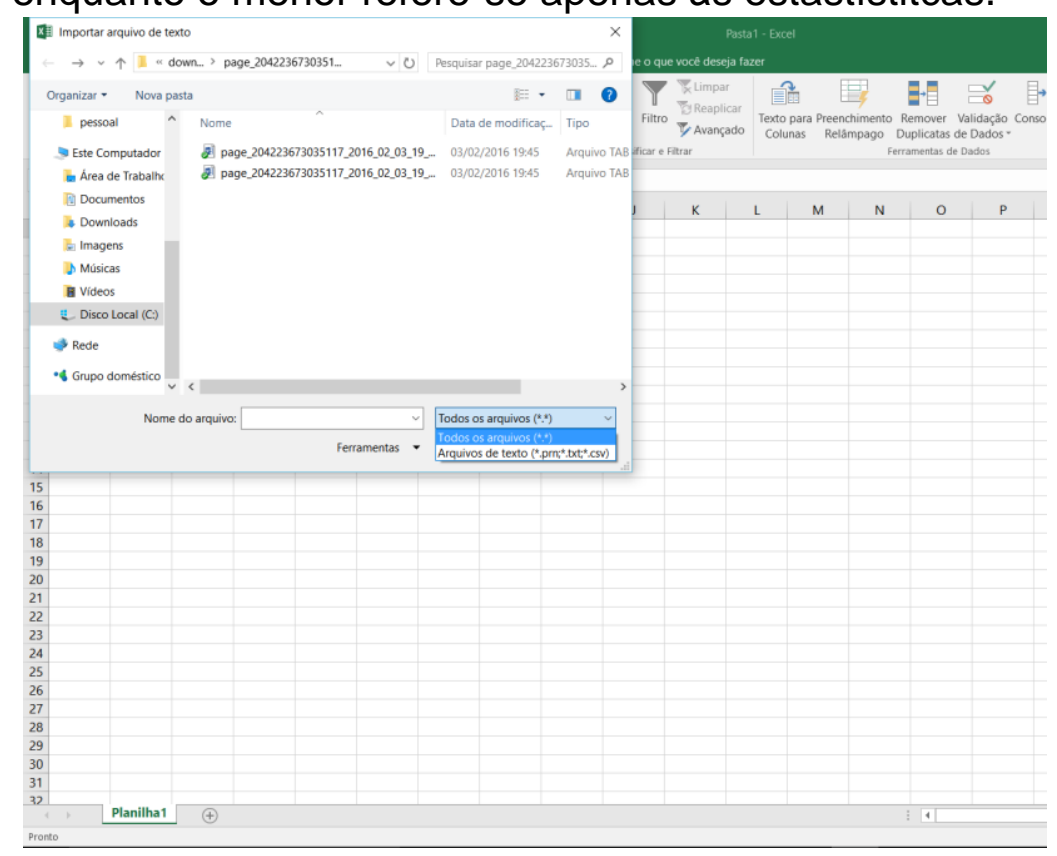


8. Marque a caixa meus dados possuem cabeçalho e selecione a opção 65001 : Unicode (UTF-8). Clique em avançar e, em seguida conclua a operação. Salve a planilha.

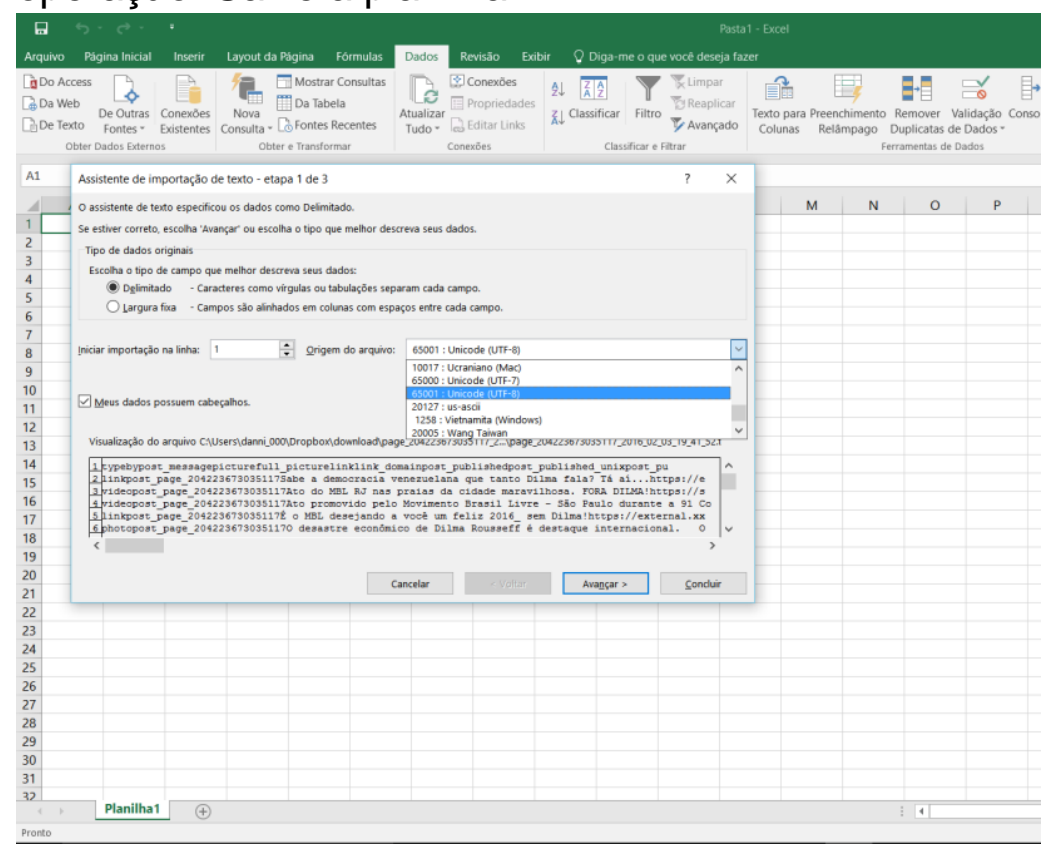

9. Abra o Nvivo. Clique em "Dados"> "Conjunto de Dados" e importe a planilha com os dados desejados. Após a codificação dos nós, os dados estarão prontos para serem classificados.

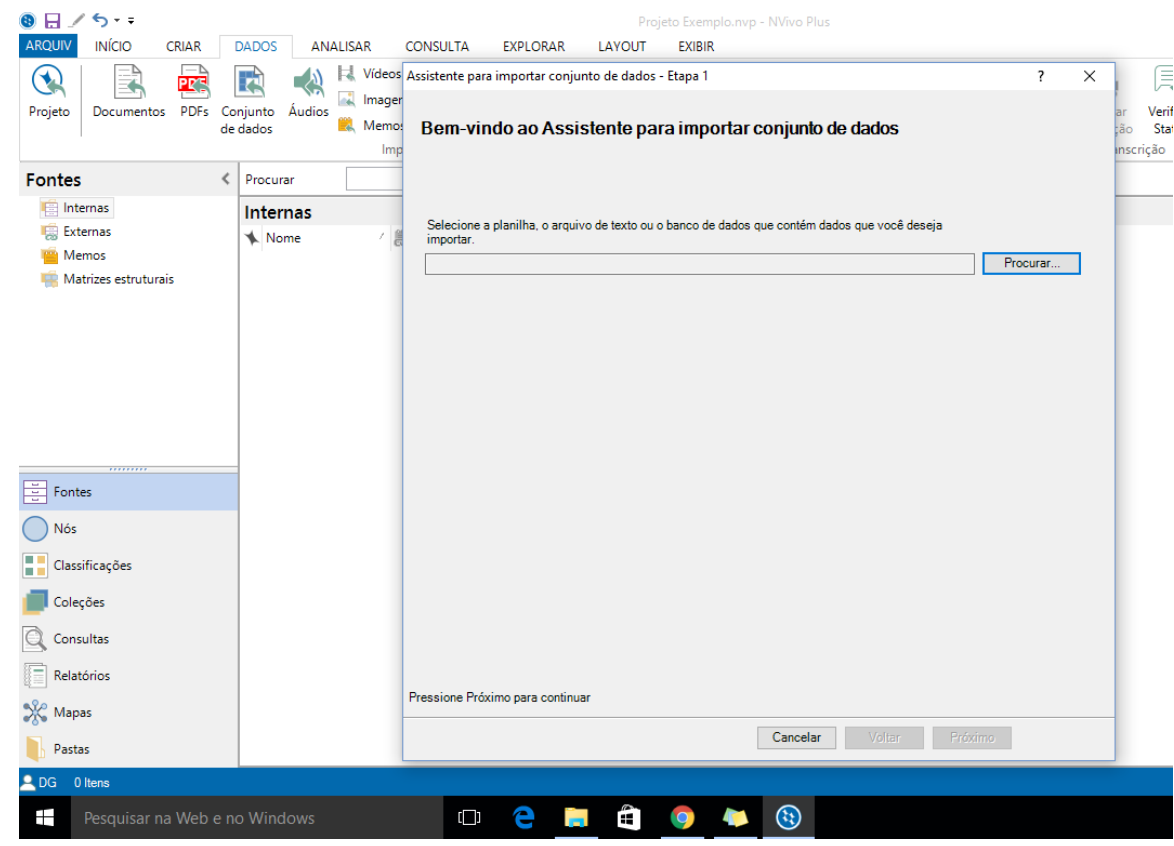


